UNIVERSIDADE DE SÃO PAULO

INSTITUTO DE ARQUITETURA E URBANIMO

Processo de Produção Habitacional: Análise do Conjunto Habitacional Vila União da Juta (São Paulo/SP)

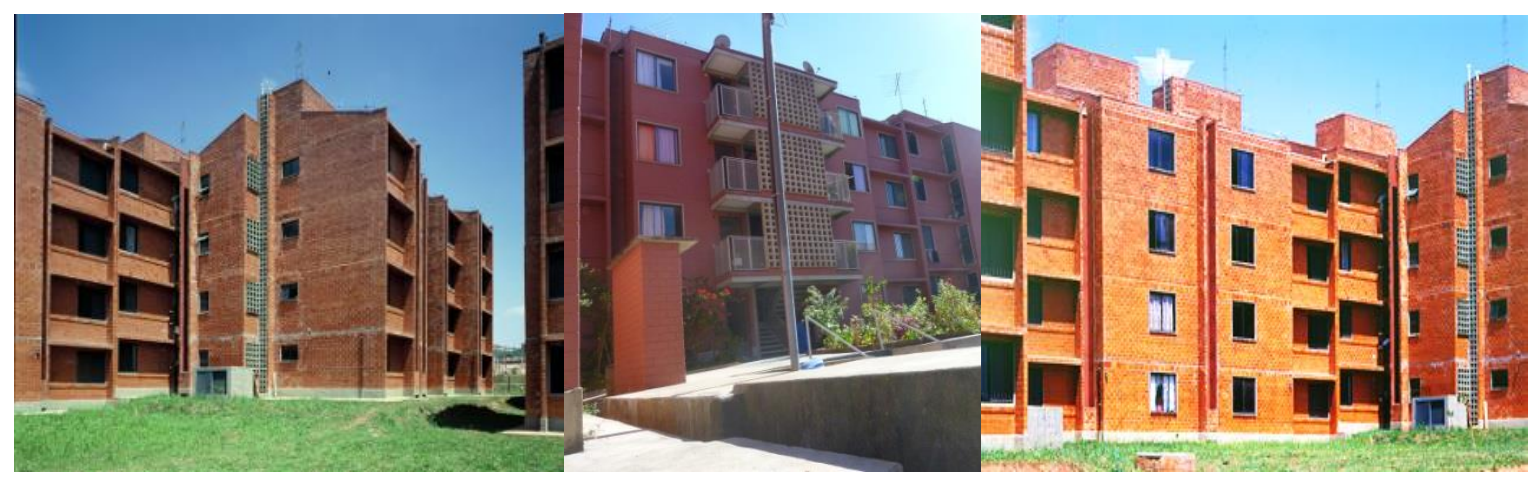

Fabrícia Mitiko Ikuta

SÃO CARLOS

2013 


\author{
UNIVERSIDADE DE SÃO PAULO \\ INSTITUTO DE ARQUITETURA E URBANIMO \\ PROGRAMA DE PÓS-GRADUAÇÃO EM ARQUITETURA E URBANISMO
}

\title{
PROCESSO DE PRODUÇÃO HABITACIONAL: ANÁLISE DO CONJUNTO HABITACIONAL VILA UNIÃO DA JUTA (SÃO PAULO/SP)
}

Dissertação de mestrado apresentada ao Instituto de Arquitetura e Urbanismo da Universidade de São Paulo (IAU/USP), para obtenção do título de Mestre.

ORIENTADOR

Prof. Dr. João Marcos de Almeida Lopes

ORIENTANDA

Fabrícia Mitiko Ikuta 


\section{AUTORIZO A REPRODUÇÃO E DIVULGAÇÃO TOTAL OU PARCIAL DESTE TRABALHO, POR QUALQUER MEIO CONVENCIONAL OU ELETRÔNICO, PARA FINS DE ESTUDO E PESQUISA, DESDE QUE CITADA A FONTE.}

Dissertação (Mestrado) - Programa de Pós-Graduação em Arquitetura e Urbanismo e Área de Concentração em Arquitetura, Urbanismo e Tecnologia -- Instituto de Arquitetura e Urbanismo da Universidade de São Paulo, 2013 .

1. Política Pública. 2. habitação social. 3. moradia popular. 4. mutirão . 5. União da Juta. 6 . projeto de arquitetura e urbanismo. I. Título. 


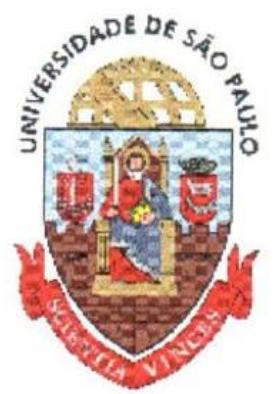

Fanus

\section{Universidade de São Paulo}

\section{RELATÓRIO DE DEFESA}

Aluno: 102131 - 7262002 - 1/Página 1 de 1

Relatório de defesa pública de Dissertação do(a) Senhor(a) Fabrícia Mitiko Ikuta no Programa: Arquitetura e Urbanismo, do(a) Instituto de Arquitetura e Urbanismo da Universidade de São Paulo.

Aos 26 dias do mês de setembro de 2013, no(a) Auditório Paulo de Camargo realizou-se a Defesa da Dissertação do(a) Senhor(a) Fabrícia Mitiko Ikuta, apresentada para a obtenção do título de Mestra intitulada:

"Processo de produção habitacional: análise do Conjunto Habitacional Vila União da Juta (São Paulo/SP)"

Após declarada aberta a sessão, o(a) Sr(a) Presidente passa a palavra ao candidato para exposição e a seguir aos examinadores para as devidas arguições que se desenvolvem nos termos regimentais. Em seguida, a Comissão Julgadora proclama o resultado:

\begin{tabular}{|c|c|c|c|}
\hline Nome dos Participantes da Banca & Função & Sigla da CPG & Resultado \\
\hline João Marcos de Almeida Lopes & Presidente & IAU - USP & APROUNDA \\
\hline Miguel Antonio Buzzar & Titular & IAU - USP & AProvanA. \\
\hline Lizete Maria Rubano & Titular & FAU-UM - Externo & ANONADA \\
\hline
\end{tabular}

Resultado Final: aprovada

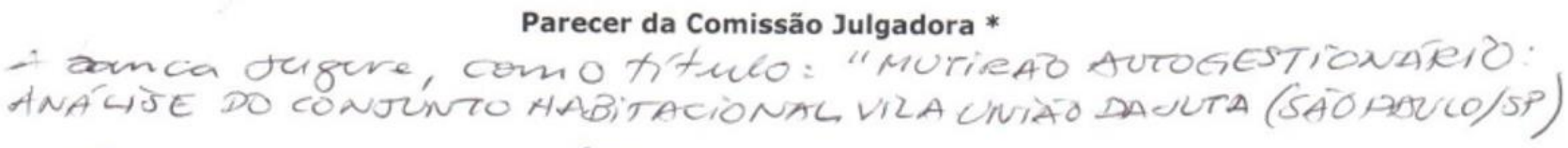

Eu, Unacceo eeestrintarrei a presente ata, que assino juntamente com os(as)

Senhores(as). São Carlos, aos 26 dias do mês de setembro de 2013.
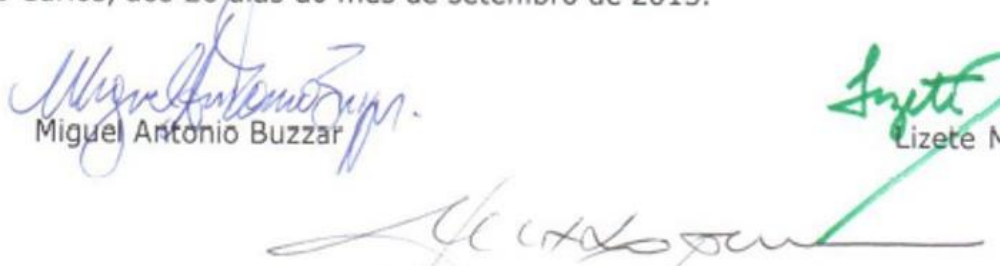

João Marcos de Almeida Lopes

Presidente da Comissão Julgadora

* Obs: Se o candidato for reprovado por algum dos membros, o preenchimento do parecer é obrigatório.

A defesa foi homologada pela Comissão de Pós-Graduação em $16 / 10 / 13$ e, portanto, o(a) aluno(a) faz jus ao título de Mestra em Ciências obtido no Programa Arquitetura e Urbanismo - Área de concentração: Arquitetura, Urbanismo e Tecnologia.

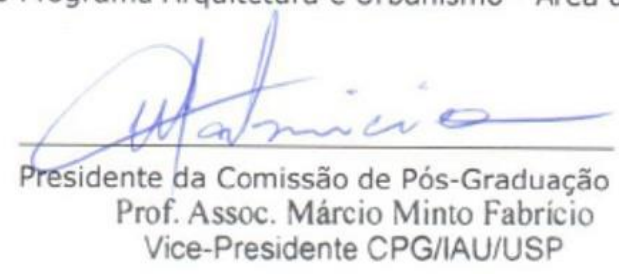


À toda minha família, com muito amor e gratidão, por todo o apoio, carinho e constante presença ao longo do desenvolvimento deste trabalho. 


\section{Agradecimentos}

Ao orientador João Marcos pelas sugestões valiosas que "abriam os olhos" e pelas contribuições direcionadas para o desenvolvimento desta dissertação.

À Fundação de Amparo à Pesquisa do Estado de São Paulo (FAPESP), pela concessão da bolsa de mestrado e pelo apoio financeiro para a realização desta pesquisa.

À Isabel, pela disposição e atenção especial e a todos os moradores da União da Juta, por dividirem comigo seu tempo, sua história e por me permitirem conhecer essa experiência mais de perto.

Aos companheiros da pós-graduação, Jader e Adriana, pelas ricas trocas de experiências.

Às amigas São Carlenses, Vanessa e Aline, pelo cuidado e atenção na "nova" cidade.

Às amigas de São Paulo, Isabela, Penélope e Kelly, que sempre abriram as portas de casa com muito carinho para me receber. A Tainá e a Valentinha, pelo companheirismo e disposição nos trabalhos de campo.

Aos amigos Prudentinos Patrícia, Ricardo, Karen, Ronald companheiros para todas as horas.

À amiga-irmã desde sempre, Juliana, por sempre orgulhar.

À minha mãe, Cidinha, (in memorian) que sempre nos encantou com sua alegria de viver, pelo seu amor puro e incondicional, seu imenso carinho, seu abraço acolhedor.

Ao meu pai, Mitsuo exemplo de serenidade, de companheirismo e de paciência. Que me ensinou e me ensina a cada dia ser uma pessoa melhor. Que sempre me apoiou em todas as minhas escolhas, mesmo quando elas doíam por dentro.

Às minhas irmãs, Fernanda, Flávia e Fran pelo apoio e incentivo constante.

Ao cunhado Jorge e a sobrinha linda Marininha que estavam sempre prontos para alegrar o dia.

Ao Fernando, amigo e companheiro de vida, pelo incentivo constante, por acreditar, por apoiar e principalmente pelo amor e cumplicidade dedicado diariamente. 


\section{Resumo}

Essa dissertação de mestrado tem como objetivo compreender o processo de produção de habitação popular, por meio da experiência do mutirão autogerido Vila União da Juta, considerando como aspectos elementares para esta pesquisa, a compreensão: do órgão financiador - a Companhia de Desenvolvimento Habitacional e Urbano do Estado de São Paulo (CDHU)-, do Programa Paulista de Mutirão (PPM) - modalidade a qual o objeto de estudo foi enquadrado - e do projeto de arquitetura e urbanismo implantado. A partir do estudo de caso, a pesquisa busca apreender as especificidades do conjunto habitacional União da Juta e dentro de um contexto mais amplo, contribuir para o debate acerca das políticas públicas habitacionais de interesse social, segundo o processo de produção. A pesquisa mostra-se relevante, tendo em vista o crescimento numérico de práticas de produção de mercado, baseada na iniciativa público-privada e a redução de práticas autogestionárias.

Palavras-Chave: Política pública, habitação social, moradia popular, mutirão da União da Juta, projeto de arquitetura e urbanismo. 


\section{Abstract}

The purpose of this article is to understand the production process of popular housing, by experiences of the self-managed community joint Vila União da Juta, considering elementary aspects to this research, the understanding: the funding organization - the Companhia de Desenvolvimento Habitacional e Urbano do Estado de São Paulo (CDHU), of the Programa Paulista de Mutirão (PPM), modality where the object of study was categorized - and of the actual architecture and urbanism project. By the study of case, the research look to learn about specifics of the housing União da Juta, and in a bigger context, to contribute to debate about housing public politics of social interest, according the production process. The research show itself relevant, due to numeric growing of the market production practices, based on the public-private initiative and reduction of self-managed practices and growing of market production, based on the public-private initiative.

Keywords: Social housing public politics, popular housing, community joint União da Juta, architecture and urbanism project. 


\section{LISTA DE FIGURAS}

Figura 1 | Luiza Erundina discursando em comício antes da conquista eleitoral em 1988

Figura 2| Relação dos Mutirões da Grande São Paulo, 1991

Figura $3 \mid 3^{a}$ Caravana à Brasília, entrega de assinaturas do Projeto de Lei de Moradia Popular, 19/11/1991

Figura 4 | Implantação do Conjunto Habitacional Zezinho Magalhães Prado, o projeto original previa cerca de 11.000 unidades

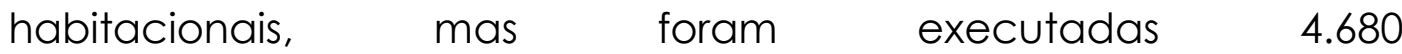
habitações

Figura 5| Conjunto Habitacional Águia de Haia, município de São Paulo

Figura 6 | Primeiras ocupações na Fazenda da Juta 79

Figura 7| Visita dos moradores às Cooperativas Uruguaias. 82

Figura 8| Planta humanizada, fev. 1992

Figuras 9 | Início das obras no Mutirão da Juta

Figuras 10 | Construção do centro comunitário no Mutirão da Juta

Figura 11 | Foto da rua onde foi implantada a Vila União da Juta - a direita, o conjunto habitacional e a esquerda, posto policial e escola de ensino médio.

Figura 12| Foto aérea da região de implantação da Vila União da Juta

Figura 13| Conjuntos habitacionais em Sapopemba e em destaque a Vila União da Juta

Figura 14| Sede da Associação de Moradores, creche e Igreja do MUJ.

Figura 15 | Implantação da Vila União da Juta 102

Figura 16| Geminação e articulação das unidades habitacionais......

Figura 17| Pátio interno formado por novos arranjos entre os edifícios

Figura18 | Escadas metálicas servindo como gabarito e andaimes..... 


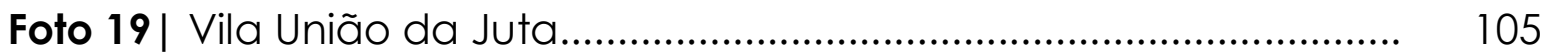

Foto 20 e 21 | Vila União da Juta, tipologias habitacionais .................... 107

Figura 22 | Planta baixa da Tipologias A, B e C respectivamente......... 108

Figura 23 | Modulação a área útil para cada tipologia do MUJ........... 114

\section{LISTA DE ABREVIATURAS E SIGLAS}

BNH Banco Nacional de Habitação

$\mathrm{CDH} \quad$ Companhia de Desenvolvimento Habitacional

$\mathrm{CDHU} \quad$ Companhia de Desenvolvimento Habitacional e Urbano

CEBs Comunidades Eclesiais de Base

CECAP Caixa Estadual de Casas para o Povo

CMP Central de Movimentos Populares

CODESPAULO Companhia de Desenvolvimento de São Paulo

FAU/USP Faculdade de Arquitetura e Urbanismo da Universidade de São Paulo

FGV $\quad$ Fundação Getúlio Vargas

FNHIS Fundo Nacional de Habitação de Interesse Social

FNRU Fórum Nacional de Reforma Urbana

FUNAPS Fundo de Atendimento à População Moradora em Habitação Subnormal

ICMS Imposto sobre Circulação de Mercadorias e Serviços

Insper Instituto de Ensino e Pesquisa

LAB-HAB Laboratório de Habitação e Assentamentos Humanos

MNLM Movimento Nacional de Lutas por Moradia

MST Movimento dos Trabalhadores Sem-Terra de Ermelino Matarazzo

MUJ Mutirão União da Juta

OIS Ordem de Início de Serviços 
ONU Organização das Nações Unidas

PCB Partido Comunista Brasileiro

FM/UMM Programa Mutirao/Unıao dos Movimento de Moradıa

PMCMV Programa Minha Casa Minha Vida

PMH Programa Municipal de Habitação

PNA PROGRAMA NACIONAL DE AUTOCONSTRUÇÃO

PPM Programa Paulista de Mutirões

PPPs Parcerias Público-Privadas

PROFILURB PROGRAMA DE FINANCIAMENTO DE LOTES URBANIZADOS

PROMORAR PROGRAMA DE ERRADICAÇÃO DE SUBHABITAÇÃO

PT Partido dos Trabalhadores

SFH Sistema Financeiro de Habitação

SNHIS Sistema Nacional de Habitação de Interesse Social

UMM União dos Movimentos de Moradia

UMM-SP União dos Movimentos de Moradia da Grande São Paulo

UNICAMP Universidade Estadual de Campinas

UPF $\quad$ Unidade Padrão de Financiamento

URBEM Instituto de Urbanismo e Estudos para a Metrópole

USINA CTAH USINA Centro de Trabalhos Para o Ambiente Habitado 


\section{SUMÁRIO}

Resumo

Abstract 8

Lista de Figuras 9

Lista de Abreviaturas e Siglas $\quad 10$

$\begin{array}{ll}\text { Introdução } & 13\end{array}$

CAPÍtULO 1 | O CONTEXTO DA PRODUÇÃO DE HABITAÇÃO DE 19 INTERESSE SOCIAL

1.1 A questão habitacional no Brasil no período 1964-1986 ................. 21

$1.2 \bigcirc$ desenvolvimento da política de habitação popular 30

"alternativa" no Estado de São Paulo

1.3 Evolução institucional da CDHU: de CECAP à CDH ........................ 43

1.4 A CDHU como agente promotora e financeira ............................. 47

CAPÍTULO 2 | UM MODO DE PRODUZIR MORADIA: DO PROGRAMA 50 MUTIRÃO UMM AO PROGRAMA PAULISTA DE MUTIRÃO

2.1 Origens da modalidade de produção ............................................ 52

2.2 Os objetivos e características da modalidade de produção .... 55

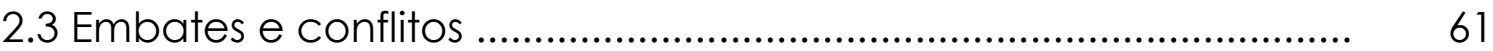

2.4 Panorama e abrangência do programa .......................................... 67

CAPÍTULO 3 | O MUTIRÃO UNIÃO DA JUTA …..........................................

3.1 Como nasceu o mutirão: o processo de associação ...................... $\quad 75$

3.2 a relação entre o estado e a UMM: o processo de negociação 83

3.3 Questionamento de paradigmas ou submissão às regras 84

estabelecidas: a elaboração do projeto arquitetônico

3.4 Fazendo a casa: o Mutirão da União da Juta ................................. 89

3.5 Aspectos projetuais do mutirão união da juta depois de vinte 95 anos de implantação

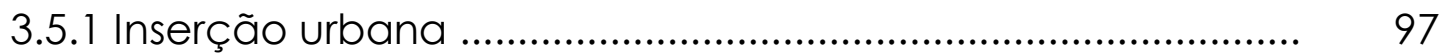

3.5.2 Implantação urbana ............................................................ 100

3.5.3 Unidade de vizinhança - Quadra .......................................... 102

3.5.4 O conjunto habitacional ......................................................... 104

3.5.5 Unidade habitacional ............................................................. 107

CAPÍTULO 4| CONSIDERAÇÕES FINAIS .................................................... 113

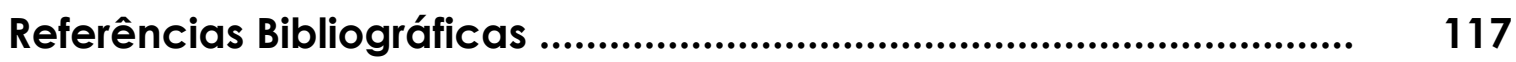

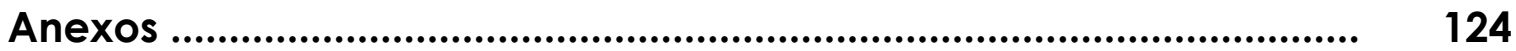




\section{INTRODUÇÃO}

Esta dissertação de mestrado é fruto de algumas inquietações decorrentes de investigação anterior sobre a temática da moradia popular, que surgiram durante a iniciação científica e a graduação em Arquitetura e Urbanismo, quais sejam: diante de um quadro de permanência das necessidades habitacionais e sendo a habitação um direito fundamental assegurado pela Constituição Federal (1988) e por diversos organismos multinacionais, como a Declaração Universal dos Direitos Humanos/ONU (1948), até que ponto determinadas ações emblemáticas podem oferecer contribuições significativas para as políticas públicas que visem à redução dos déficits habitacionais? Será que os conjuntos habitacionais realmente apresentam propostas diferenciadas em relação aos processos de produção da habitação e à qualificação arquitetônica e urbanística? E uma terceira questão que diz respeito ao modelo dominante nas atuais formas de provisão da habitação: porque a aposta na iniciativa público-privada e na baixa qualificação arquitetônica e urbanística dos projetos de habitação popular? Em outras palavras, o que nos preocupava era a seguinte questão: quais as práticas "alternativas" àquelas historicamente promovidas para a habitação social?

Desta forma, essas questões serviram de base para ampliarmos e aprofundarmos o debate sobre a produção da moradia popular e seus inúmeros desdobramentos. Uma primeira pesquisa bibliográfica em diferentes textos, artigos, dissertações e teses que abordam assuntos relacionados à habitação popular, indicavam que a questão habitacional, não se resumia basicamente a resolução do problema do déficit habitacional e, sobretudo, que a produção de moradia popular envolveria questões mais amplas, para além do trabalho técnico do arquiteto e urbanista, a produção habitacional também abrangia a questão política. 
Sendo assim, tornava-se preciso entender não apenas o produto (casa), mas sim todo o processo de produção habitacional, para além do projeto arquitetônico e urbanístico, incorporando questões relacionadas à gestão e participação popular e num contexto mais amplo as políticas públicas de habitação popular.

Desta maneira esta dissertação de mestrado tem como objetivo investigar a gênese de um momento histórico específico de desenvolvimento da política habitacional no Estado de São Paulo, em especial de construção de uma política habitacional alternativa, baseada no mutirão autogerido que resultaram em um produto arquitetônico e urbanístico diferenciado.

Focada na experiência do Mutirão União da Juta (MUJ), em São Paulo, o trabalho buscou fornecer elementos para uma discussão a respeito do processo de produção da moradia popular através de mutirão autogerido, considerando como aspectos importantes a compreensão do órgão financiador - Companhia de Desenvolvimento Habitacional e Urbano (CDHU), do Programa Paulista de Mutirão (PPM) ao qual o objeto de estudo foi enquadrado e o projeto de arquitetura da Vila União da Juta.

O ano de 2012 celebrou os 20 anos de história do Mutirão União da Juta, fato que nos motiva a resgatar a longa trajetória desta experiência, que corre o risco de se tornar invisível diante da prevalência das tradicionais formas de provisão habitacional. E, ainda que esta, seja uma experiência pontual, nos trouxe algumas considerações sobre este momento de inflexão que deixou lastros de transformação político-social e uma importante contribuição para os projetos que simbolizam boas práticas arquitetônicas e urbanísticas.

Mas antes, é preciso em primeiro lugar definir exatamente, o que entendemos chamar como mutirão autogerido. Neste caso, estamos falando de um tipo específico de enfrentamento da questão habitacional: "Para além do mutirão - em que concorre apenas a forma simples de 
aplicação de mão-de-obra do futuro morador -, o que pretendemos abordar é o mutirão autogerido"'. O mutirante aqui participa no projeto, na obra e em todo o processo produtivo, como sujeito: futuro proprietário, operário e mutuário.

Dessa forma, o mutirão autogerido aparece com o objetivo de reconhecimento de sua condição por parte do Estado, ou seja, visando desenvolver mecanismos de legitimidade, com dimensões emancipatórias. Diferenciando-se, portanto da autoconstrução como "processo de trabalho calcado na cooperação entre as pessoas, na troca de favores, nos compromissos familiares"2, predominante no intenso processo de crescimento da urbanização brasileira.

Argumenta-se que o mutirão não se apresenta como "solução" para o problema da moradia popular em nosso país, pois o mesmo é apenas um dos elementos dentre uma série de problemas articulados à macroestruturação social do capitalismo que impedem a universalização do acesso à moradia popular.

A partir das reflexões e considerações apresentadas até o presente, estruturamos esta dissertação da seguinte maneira:

O primeiro capítulo apresenta o contexto da produção de habitação de interesse social no Estado de São Paulo, a partir da década de 80, quando a ação política do governo parece caminhar para o desenvolvimento de uma política habitacional, em decorrência de um cenário caracterizado por altas pressões dos segmentos populares. Não pretendemos retomar toda a extensa e consolidada literatura sobre o modelo de Política Habitacional Nacional desenvolvido pelo Banco Nacional de Habitação (BNH), interessa-nos contextualizar a trajetória que permeou o

\footnotetext{
1 Idem, 2006.

2 MARICATO, (1979, p. 75).
} 
acesso à habitação com foco na atuação do governo do Estado e no desenvolvimento da Companhia de Desenvolvimento Habitacional e Urbano do Estado de São Paulo (CDHU).

Desta forma, também abordamos a evolução institucional da CDHU: de CECAP à CDHU. Neste item iniciamos com a Caixa Estadual de Casas para o Povo (CECAP autarquia), surgida no bojo de um processo de descentralização política, até chegar ao que é hoje a Companhia de Desenvolvimento Habitacional e Urbano do Estado de São Paulo (CDHU) e a sua controversa concepção de provisão pública de habitação popular. Buscamos nos aproximar ainda mais da CDHU para compreender melhor o seu papel como agente promotor e financeiro de um programa de mutirão e autogestão.

No segundo capítulo procuramos investigar o surgimento de um novo programa de construção de habitações populares inaugurado na CDHU: o Programa Paulista de Mutirão (PPM). No primeiro momento foram apresentadas as origens desta modalidade de produção, os antecedentes históricos e as condições de formulação e negociação da proposta de implantação dessa modalidade de produção - mutirão e autogestão -, tendo por base a experiência dos mutirões com autogestão em São Paulo, sua vinculação com a União dos Movimentos de Moradia (UMM), a importante influencia das Cooperativas Uruguaias de Ajuda Mútua como alicerce para a proposta original deste programa.

Também exploramos os elementos que constituem o programa, em seus diversos formatos, tais como: os objetivos, os atores envolvidos, as formas de financiamento, as fontes de recursos, as famílias beneficiadas, os critérios de seleção das famílias, a renda mínima exigida e, principalmente, a forma de participação dos mesmos.

Desta maneira, podemos entender o modus operandi, ou seja, o funcionamento do mesmo, recuperando as principais críticas formuladas aos 
diversos formatos assumidos pelo programa e avaliando como as questões centrais de luta dos movimentos sociais e assessorias técnicas foram incorporadas e conformadas em um discurso de universalização do direito à moradia digna e quais os reflexos práticos destes aspectos no formato final do programa. A questão que se apresenta é: qual foi a resposta estatal para as pretensões originais dos movimentos? Ocorreram mudanças no formato e no caráter do programa? Como o Programa de mutirão funciona hoje na CDHU? Desse modo, buscaremos desvendar quais os principais avanços e retrocessos pelas quais passou esta modalidade de produção.

Tanto a construção teórica como os resultados de sua implementação evidenciam um distanciamento do Estado em relação aos conflitos, tensões e demandas populares, estabelecendo posturas contraditórias - e, boa parte das vezes, antagônicas - resultando em uma abordagem que coloca a autogestão no centro da reflexão. Como pano de fundo, ficam em aberto às questões quanto à forma de implementação de um programa dessa natureza no âmbito de uma agência estatal.

No terceiro capítulo apresentamos o estudo de caso do Mutirão da Vila União da Juta. Iniciamos com o processo de formação da associação União da Juta; a articulação, as formas de organização e de mobilização coletiva e as primeiras ocupações como momentos de ampliação do campo de tensões políticas.

Em seguida, buscamos desvendar a relação entre o Estado e a população durante o processo de negociação para a construção do conjunto habitacional. Quais eram os conflitos e os embates que estavam em jogo? Buscamos entender a dimensão política deste processo e o universo de possibilidades que estavam colocados naquele momento; a habilitação das famílias e o financiamento das habitações; a operacionalização da CDHU e formulação/definição da Política Habitacional para baixa renda: regras, dispositivos e procedimentos. 
Também procuramos desvendar quais os papéis dos sujeitos sociais envolvidos: a contribuição da assessoria técnica, da associação e dos mutirantes; a concepção de participação; a discussão do projeto urbanístico e arquitetônico. Neste item buscamos entender se a elaboração do projeto arquitetônico foi caracterizada por uma tentativa de questionamento de paradigmas ou se ele derivou em submissão às regras estabelecidas pela CDHU.

Consideramos importante mostrar como aconteceu a construção, a organização do canteiro de obras, a concepção de autogestão da obra e dos recursos financeiros, o papel das mulheres no mutirão, as inovações nos aspectos construtivos, a discussão sobre equipamentos, infraestrutura e serviços e a inauguração do conjunto habitacional.

Assim, no último capítulo retomamos as principais questões sobre a importância de experiências como esta, ou seja, passados tantos anos, qual avaliação podemos fazer desta experiência? Quais foram às limitações e as possibilidades deste modelo de produção habitacionale Quais são os desafios para a produção de moradia autogestionária?

Contudo, longe de estabelecer um argumento fechado, buscamos aqui, construir uma perspectiva crítica às questões que envolvem o debate para além das dicotomias, isto é, "sem cair na tentação folclorista de tecer loas ingênuas ao mutirão"3, nem tão pouco condenando à extinção das políticas habitacionais alternativas, mas sim, apresentando os limites e as potencialidades que possuem esse tipo de intervenção e as formas com que esses diferentes atores sociais operam dentro de um campo de possibilidades restritas.

\footnotetext{
3 Lopes; Rizek (2006, p. 45)
} 


\section{CAPÍ́TLLO 1}

\section{O CONTEXTO DA PRODUÇÃO DE HABITAÇÃO DE}

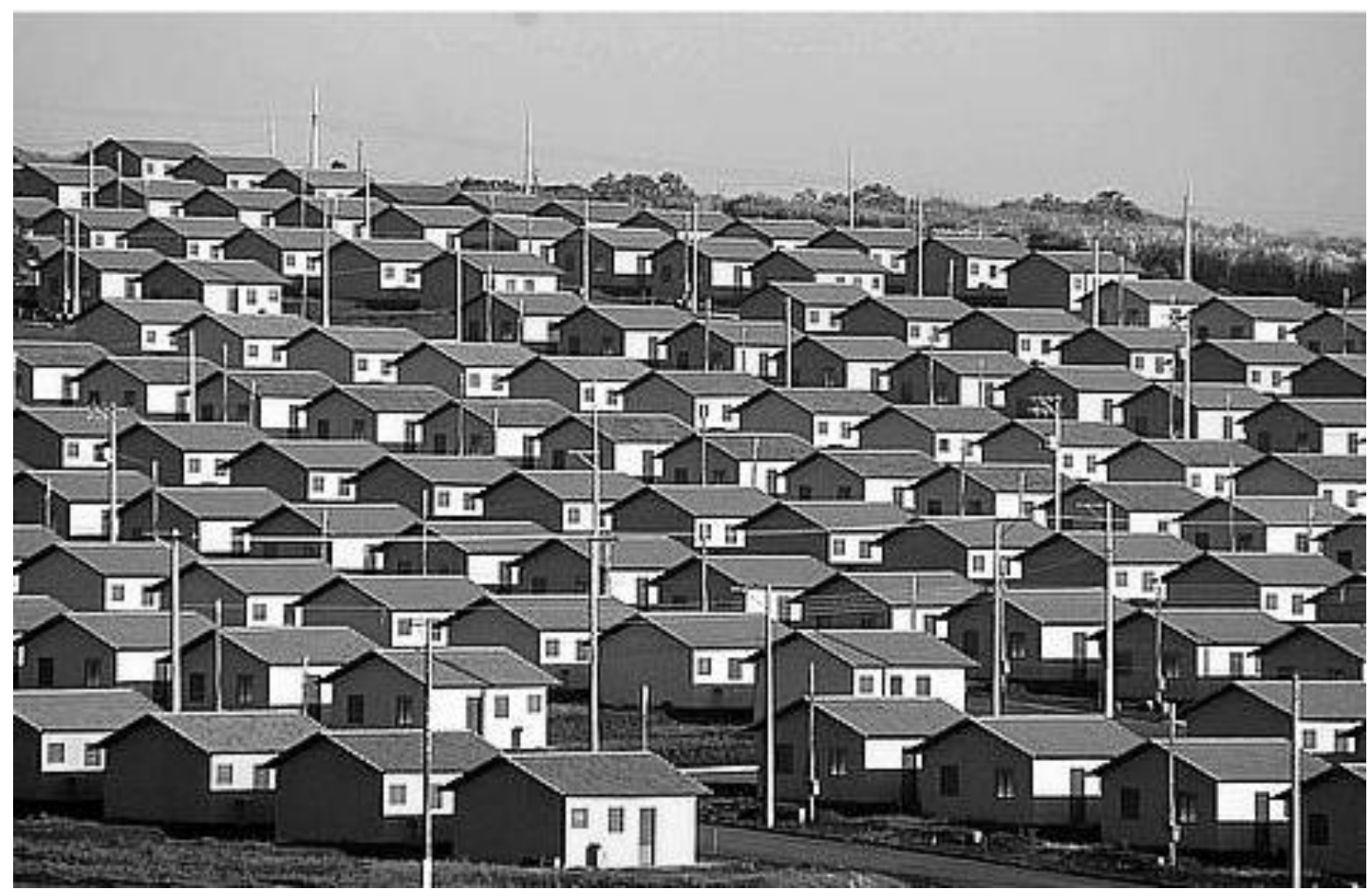

Fonte: Portal do Governo do Estado de São Paulo, Daniel Guimarães. 


\section{CAPÍtULO 1| O CONTEXTO DA PRODUÇÃO DE HABITAÇÃO DE INTERESSE SOCIAL}

Como ponto de abertura para este capítulo, efetuamos uma contextualização da trajetória que permeou o acesso à habitação popular no país, entre os anos de 1964 até 1986. Abordamos de maneira sintética, o processo de implementação e formulação de políticas públicas e programas habitacionais desenvolvidos pelo governo Federal, evidenciando os aspectos mais relevantes para a compreensão da política estadual durante a década subsequente.

Desta forma, não retomamos toda a extensa e consolidada literatura sobre o modelo de Política Habitacional Nacional desenvolvido pelo Banco Nacional de Habitação (BNH), interessa-nos destacar o momento de crise do Sistema Financeiro de Habitação (SFH) e o conjunto de heranças deixadas por este modelo que influenciaram as políticas habitacionais desenvolvidas pelos estados.

A partir da década de 1980, ocorreram mudanças significativas no sentido de descentralizar as fontes de recursos entre os três entes públicos do Federalismo. Também é neste período que, no âmbito das lutas pela democratização, as políticas habitacionais desenvolvidas pelos estados ganharam maior relevo. Assim, o foco da análise concentra-se na atuação do governo do Estado de São Paulo e, em especial, no desenvolvimento da companhia responsável pela execução de suas políticas de habitação - a CDHU.

À medida que os diferentes atores - Estado, órgãos públicos, arquitetos e movimentos sociais - se cruzam engendram um cenário ímpar na história do país e estabelecem novas relações de poder, que constituíram-se em importantes horizontes para a formação de programas de habitação popular "alternativos" (tema abordado no capítulo 2). 


\subsection{A questão habitacional no Brasil no período de 1964-1986}

A implementação e formulação de políticas públicas e programas habitacionais, a partir de 1964 até 1986, já foram tema de inúmeros estudos4, dentre os quais alguns se tornaram paradigmáticos, sobretudo, no que diz respeito ao Banco Nacional de Habitação (BNH), principal agente do Sistema Financeiro de Habitação (SFH) 5 e os seus desdobramentos políticos e econômicos.

A análise desses estudos nos permite apontar que o BNH possuía como uma de suas principais características a articulação entre agentes públicos e privados para a constituição da política habitacional do período pós-64. Entretanto, como era uma instituição financeira e ao mesmo tempo efetuava o papel de planejador de políticas habitacionais sociais, acabava proporcionando a "acumulação privada de setores da economia envolvidos com a produção habitacional"6.

Desta maneira, percebemos duas fortes tendências da política habitacional, do período pós-64. A primeira refere-se à abordagem mais comumente apresentada e diz respeito a uma necessidade de responder à urbanização acelerada do país e ao aumento da demanda habitacional7 Este processo ocorreu em um cenário pautado por instrumentos de planejamento urbano tecnocrático8, onde a problemática da habitação

\footnotetext{
${ }^{4}$ Azevedo (1982), Bolaffi (1979), Valladares (1982).

5 O SFH e o BNH foram criados em 21/08/1964 pela Lei $n^{\circ} 4.380 / 64$, tinham como objetivo coordenar a política habitacional do país e criar um sistema de crédito habitacional permanente, através do Fundo de Garantia por Tempo de Serviço (FGTS) e do Sistema Brasileiro de Poupança e Empréstimo (SBPE).

${ }^{6}$ Royer $(2002$, p.10).

7 Conforme Santos (2008), em 1940, a taxa de urbanização brasileira era de $26,3 \%$ e, em 1980, atinge 68,86\%, ou seja, em quarenta anos o percentual de população urbana triplicou.

8 Villaça (1998), utiliza-se da expressão "planejamento urbano tecnocrático", para caracterizar um modelo de governabilidade funcional, baseado no uso da técnica em detrimento da política, muito presente no processo de industrialização do país.
} 
social era pensada muito mais em termos quantitativos em detrimento da qualidade arquitetônica. Desta maneira, o combate às desigualdades socioespaciais não era prioridade e, por isso, a situação da moradia popular agravava-se ainda mais.

A segunda tendência reporta-se a um enfoque menos evidente, mas muito importante, que seria a necessidade de estruturação do Estado autoritário e uma "clara intervenção do Estado na reprodução econômica, favorecendo setores da economia ao disponibilizar parte do fundo público para a execução de programas e obras", já que ○ financiamento era concedido direto às construtoras e não ao usuário final. Neste sentido, também indica um "atendimento da demanda do capital, pelo oferecimento de parcela do fundo público à dinamização de setores da iniciativa privada"9. Assim, quando o Estado deixa a produção habitacional nas mãos do setor privado, interessado em obter o maior lucro possível, questões importantes como o atendimento efetivo à população de baixa renda ${ }^{10}$ e a qualidade arquitetônica deixam de ser prioritários.

Este fato é indicativo da baixa qualificação arquitetônica e urbanística presente em grande parte dos conjuntos habitacionais do modelo SFH, dentre as principais características podemos citar: padronização das habitações, localização periférica e ausência de infraestrutura, serviços e equipamentos públicos básicos. É justamente como contraponto a este modelo, que analisamos o projeto da Vila União da Juta (assunto aprofundado no capítulo 3).

Conforme Royer (2002), estas duas tendências da política habitacional, do período pós-64, constituíram o "cerne do sistema",

\footnotetext{
9 Royer (2002, p.11).

10 Segundo Bolaffi (1986), O SFH/BNH financiou cerca de 4,4 milhões de unidades habitacionais, produção numericamente expressiva, mas, apenas $18 \%$ do total de recursos, foram destinados às famílias com rendar inferior a 5 salários mínimos (essas famílias compunham três quartos da população brasileira).
} 
estiveram presentes desde as suas origens, permaneceram durante seu desenvolvimento e influenciaram fortemente a atuação dos órgãos derivados do SFH. Como exemplo, podemos citar a Companhia de Desenvolvimento Habitacional e Urbano do Estado de São Paulo (CDHU), principal agente promotor da política habitacional, que incorporou muito dessas características (conforme abordado capítulo 2).

A ênfase nesta dupla abordagem faz uma importante contraposição aos estudos que afirmam a omissão do Estado ou desinteresse pelos problemas das camadas populares do país. O Estado possui papel fundamental na criação de políticas que representem a intermediação dos mais diferentes interesses de classe. Quando o Estado "aparenta" não agir, na verdade, ele está mantendo um modelo de provisão habitacional baseado na aposta na iniciativa privada como agente do processo e dando prioridade ao desenvolvimento econômico em detrimento do desenvolvimento social.

Assim, por meio de organismos administrativos estaduais e municipais, a estrutura de financiamento da habitação baseava-se no repasse dos recursos para a iniciativa privada, ou seja, privilegiava o interesse próprio dos agentes executivos e mobilizava a "indústria de construção civil e a indústria de materiais de construção" Azevedo e Andrade (1982, p. 62). Para o autor, esta forma de atuação fundamentada na "centralização normativa e a descentralização executiva", formaram as condições adequadas que asseguraram a eficiência do funcionamento do SFH até a extinção do BNH, quando o sistema terá que passar por mudanças importantes. Do mesmo modo, a instituição de um banco para tratar das políticas de habitação popular como item do desenvolvimento social que visa o "bem público" deslocou paulatinamente o Estado das suas obrigações sociais.

Quanto aos resultados, a literatura é bastante clara ao afirmar o êxito do sistema de financiamento baseado no desenvolvimento da indústria de construção civil e de um mercado imobiliário. Contudo, o sucesso do SFH se 
esgota na sua própria raiz contraditória, ou seja, ao mesmo tempo em que se aproximava do desenvolvimento efetivo de um mercado de unidades habitacionais, se distanciava cada vez mais dos objetivos sociais ${ }^{11}$ e de desenvolvimento urbano.

Diante deste quadro, a capacidade do Estado de enfrentamento das necessidades habitacionais da população brasileira ficou bastante comprometida e "confundiu-se progressivamente com mecanismos de erradicação do déficit, em detrimento da qualidade da construção e da integração da moradia com outros vetores de inserção urbana"12. Criou-se, portanto, uma inversão de valores e o critério quantitativo - elevado número de unidades habitacionais produzidas - passou a ser a medida da eficiência da política.

Segundo Royer (2002) o setor foi progressivamente se deteriorando, mesmo com algumas alterações nos programas habitacionais, manteve-se a mesma estrutura de funcionamento do sistema e o não atendimento aos setores de menor renda, que compunha uma das metas mais importantes do modelo. Essa constatação só ocorreu no final da década de 1970 e, a partir daí, aumentou-se os gastos públicos no chamado mercado popular, com a intenção de recuperar o objetivo inicial que inspirou a criação do $\mathrm{BNH}$.

A autora esclarece que para dar atendimento às faixas de menor renda sem onerar os cofres públicos, foram realizados programas que davam destaque para a autoconstrução:

Diante da crise fiscal do Estado, no entanto, optou-se por reduzir os custos de produção, com a introdução de programas alternativos que pudessem atender as demandas das faixas de menor renda sem onerar excessivamente os cofres públicos. A principal base de sustentação desses programas foi a autoconstrução. (ROYER, 2002, p.12 - grifos do autor).

\footnotetext{
${ }^{11}$ Cf. Azevedo e Andrade (1982, p. 60).

12 Royer (2002, p.1).
} 
A partir deste momento, a autoconstrução passou a ser incentivada como solução habitacional, tanto em nível nacional como internacional. Logo, para John Turner (1977), essa modalidade de autoempreendimento possuía papel instrumental, capaz de impulsionar soluções para a questão habitacional. Segundo o autor, a ideia central partia do pressuposto de que a adequação da moradia às necessidades dos mais pobres tornava-se uma solução mais interessante quando confrontada com os grandes conjuntos habitacionais produzidos pelo Estado. Também representava maior participação do futuro morador nas questões referentes ao projeto da casa. Neste âmbito, a autoconstrução passou a ser estimulada pelo Estado como uma alternativa relevante para sanar o déficit habitacional ${ }^{13}$.

Criou-se, portanto, uma ideia controversa sobre a autoconstrução, como representação de uma solução para a problemática da habitação social, pois, para este autor, as áreas de ocupação irregular eram uma expressão típica do processo de crescimento urbano e representavam formas "espontâneas" de produção de moradias mais baratas que atendiam melhor as necessidades de seus moradores. Neste sentido, era uma ideia muito recomendável para países de Terceiro Mundo.

Todavia, consideramos ser preciso ponderar as colocações de Turner (1977), pois elas podem indicar uma total legitimação da ausência Estatal na resolução dos problemas da moradia popular. Turner não considerou o fato de que a questão da habitação social está inserida dentro de um conjunto mais complexo de relações sociais profundamente contraditórias e conflitivas.

Além disso, em um contexto de crise econômica a emergência de uma política dessa natureza passou a assumir uma conotação de redução

13 Cf. Silveira (1987), as ideias de Turner, foram incorporadas e incentivadas por organismos internacionais (Banco Mundial-BM e do Banco Interamericano de Desenvolvimento-BID) como políticas de habitação popular para a consolidação de áreas de ocupação irregular. 
dos custos, ao eliminar a remuneração da mão-de-obra dos futuros moradores, na construção da moradia.

No Brasil, a partir da década de 1970, a autoconstrução foi introduzida como forma de acesso à habitação por intermédio dos programas alternativos de habitação popular formulados pelo Banco Nacional de Habitação (BNH). Lima (2005), afirma que a autoconstrução espontânea era muito onerosa para a população de baixo poder aquisitivo e por isso foi "necessário um agente que estimulasse o desenvolvimento desse modo de produção" (p. 12). Assim, o objetivo central dos programas "alternativos" no país foi implementar: linhas de financiamento a lotes urbanizados e recursos para aquisição de materiais de construção, isto é, soluções marginais ao sistema que permitissem reduzir as despesas no processo de produção. Trata-se da dificuldade de universalizar o acesso à habitação,
principalmente à população de renda mais baixa, sem a existência
de subsídio estatal ou sem a alocação de recursos públicos a fundo
perdido. No transcorrer do tempo, a mediação da política pública
pelo mercado mostrou-se profundamente excludente, exigindo
soluções distintas para as parcelas da população sem renda ou sem
acesso a financiamento. Outra nota importante a destacar, foi o
tratamento dispensado a essa parcela da população, relegada a
programas marginais, passando de foco da política principal para
objeto de programas alternativos. (ROYER, 2002, p.13 - grifos do
autor)

O primeiro programa não convencional a ser implantado foi $O$ PROGRAMA DE FINANCIAMENTO DE LOTES URBANIZADOS (PROFILURB), em 1975, com o objetivo de expandir o atendimento das faixas de rendas mais baixas, produzir loteamentos populares, com quadras e lotes demarcados, dotados de condições de saneamento e infraestrutura básica ${ }^{14}$. No PROFILURB, a construção da habitação do tipo embrião foi destinada ao futuro morador de acordo com suas possibilidades financeiras e prioridades individuais. Este programa teve resultados pouco significativos.

${ }^{14}$ Cf. Royer (2002. P. 12). 
Logo na sequência, em 1979, foi implantado o PROGRAMA DE ERRADICAÇÃO DE SUBHABITAÇÃO (PROMORAR), que tinha como objetivo promover a urbanização e o melhoramento de favelas. Ao invés de remover os moradores, buscavam a instalação de infraestrutura e equipamentos comunitários e a recuperação de áreas deterioradas. O grande avanço do programa está no reconhecimento à realidade das favelas e na sua intenção de promover a requalificação do espaço urbano dessas áreas. Contudo, segundo Royer (2002), a regularização fundiária, ou seja, a legalização da posse da terra foi o grande obstáculo para a concretização desses avanços. Sendo assim, este programa foi mais um instrumento para contornar a crise econômica e conter qualquer tipo de ação coletiva das famílias pobres que emergiam em áreas do tipo favelas.

Em 1984, foi criado O PROGRAMA NACIONAL DE AUTOCONSTRUÇÃO (PNA) e o Projeto João de Barro devido à ampliação da demanda habitacional e aumento das pressões externas ao país, postuladas por John Turner. Desta forma, o programa previa a autoconstrução assistida, ou seja, por meio de recursos públicos o mutuário realizava a construção da sua própria habitação. Para Royer (2002), este programa significou a "institucionalização de práticas cotidianas da população urbana", ou seja, era um programa que apenas formalizava a autoconstrução como prática comum entre a população pobre. Ainda neste sentido, foi mais uma forma de transferir para a população carente a resolução dos próprios problemas.

Esses programas alternativos apresentaram resultados ínfimos perante a demanda habitacional. Além disso, deixou a mostra o posicionamento paradoxal do Estado que, em meio ao regime ditatorial, utilizou-se de programas que preconizavam a participação popular e a descentralização, como discurso a favor dos seus interesses. Também demonstrou o fracasso do Estado enquanto formulador de uma política nacional de habitação popular. 
Dois anos após a implantação do projeto JOÃO DE JARRO evidenciouse o colapso do $\mathrm{SFH}$ e do $\mathrm{BNH}$, principalmente devido à projeção de muitas características negativas como fraudes, prestações em desacordo, inadimplência, baixos investimentos, etc. Imbricadamente a este processo começou a ocorrer certa mobilização social e politização da questão da moradia digna.

Para superar a desarticulação das políticas públicas de habitação, em nível federal, ocorreu no final da década de 1980, no estado de São Paulo, uma busca por mecanismos que viabilizassem novas condições institucionais e financeiras para o desenvolvimento de uma política habitacional paulista. Isso ocorreu porque com a crise do SFH e aumento das pressões sociais, foi necessário buscar novas fontes de financiamento que garantissem fluxo permanente de recursos financeiros e oferta de equipamentos para o setor. De acordo com Arretche (1990, p. 32):

...refere-se à reabilitação da Companhia Estadual encarregada do financiamento e da produção de novas unidades habitacionais, que até então operava com repasses, via SFH, de verbas federais. No entanto, isso passaria também por uma alteração funcional e administrativa dos modelos operacionais até então usados pelo SFH.

A Companhia Estadual encarregada da produção e do financiamento da habitação no estado de São Paulo é a atual Companhia de Desenvolvimento Habitacional e Urbano (CDHU). Sua atuação, cujos detalhes serão abordados no item 1.3, estava vinculada ao SFH/BNH, uma vez que, o modelo previa essa articulação do governo federal com todos os níveis da federação para a promoção e execução da política habitacional.

$\mathrm{Na}$ tentativa de compreender a dinâmica de funcionamento institucional do $\mathrm{SFH} / \mathrm{BNH}$ é relevante observar que o sistema, embora integrado, manteve as decisões centralizadas e fragilizado pela crescente crise financeira esse sistema se desarticulou. Segundo Royer (2002), essa desarticulação ocorreu devido à fragmentação institucional e financeira do 
SFH, que em meados dos anos 1980, levou a desestruturação do BNH, culminando com o ápice da crise da política habitacional.

A autora acrescenta que dentre as causas da crise do SFH destaca-se: a queda na arrecadação do FGTS, associada à redução dos salários e consequente alta da inadimplência, desemprego, saques elevados das contas do fundo e crescente informalização da economia. Com base em Melo (1993), afirma, ainda, que o setor também foi fortemente afetado pelo Plano Cruzado, uma vez que causou grandes perdas patrimoniais ao $\mathrm{BNH}$ e "gerou uma crise no SFH por conta da corrida aos depósitos em cadernetas de poupança" (p. 20). Esta crise do SFH e consequente extinção do BNH em 1986 coincidiram com a crise do regime militar e início do processo de abertura gradual do país, conforme abordamos no item 1.3.

Assim, quando observamos a atuação Estatal por meio do SFH/BNH, pouco podemos afirmar sobre o real enfrentamento das necessidades habitacionais do país. O que mais chama a atenção é o fato do sistema ocasionar um estímulo ao setor imobiliário e perpetuar a "Ideologia da casa própria" que, segundo Azevedo e Andrade (1982), gera "estabilidade social", cria "aliados da ordem" e, se possível, obtém delas o apoio político. Deste modo, a habitação como ideologia coloca a aquisição da casa própria como questão central quando, na verdade, visa garantir a "manutenção do padrão de modernização conservadora trilhado pelo país desde 1964". (ROYER, 2002, p. 168)

Desta forma, tendo em vista o debate sobre a questão habitacional no Brasil, no período entre 1964-1986, podemos afirmar que o Mutirão União da Juta, cujos detalhes estão no capítulo 3, representa uma experiência que vai contra o curso da história, no sentido de negar formas de políticas convencionais e de tentar produzir outras arenas políticas, que reflitam de forma significativa na ampliação dos espaços de experimentação democrática. 


\subsection{0 desenvolvimento da política de habitação popular "alternativa" no Estado de São Paulo}

As primeiras abordagens voltadas para o tema da moradia popular construída por meio de mutirão autogerido no Brasil se inserem no contexto do final do "milagre econômico", na passagem dos anos 1970 para os anos 1980, já na esteira de um paulatino afrouxamento nas contenções do regime militar e de uma possível falência do nacional desenvolvimentismo.

Particularmente, há uma circunstância específica, uma espécie de bifurcação ou derivação, originada a partir dos mecanismos ortodoxos de financiamento da produção habitacional vigentes desde a implantação do Banco Nacional de Habitação (BNH), em 1964, um ramo heterodoxo de provisão da moradia para os mais pobres que articulava iniciativas de autoconstrução, compondo aquilo que se convencionou chamar de "programas alternativos".

A própria ideia de produzir casas populares de maneira "alternativa", remete ao caráter não convencional que estes projetos assumem desde o seu nascimento, inclusive porque utilizam como mão-de-obra o futuro morador. Mas, vale ressaltar que, originalmente esses programas refletem uma saída encontrada pelo Estado para dar resposta às amplas pressões sociais que vinha sofrendo e como necessidade histórica de proporcionar estabilidade social para "acalmar as massas populares". Nas palavras de Royer (2002, p. 3), "as questões de operação dos mecanismos de legitimidade estão no foco do problema".

Durante a segunda metade da década de 1970 e início dos anos de 1980, a sociedade civil começa a se reorganizar em movimentos sociais. É neste período que, conforme Sader (1988), "novos personagens entram em cena" e tentam se rearticular e buscar novas dimensões da política para resolução dos problemas sociais urbanos. 
Conforme, Sader (1988), se até a primeira metade da década de 1970 , as práticas sociais dos trabalhadores eram determinadas pela lógica do Estado e representadas como reflexo de um processo de alienação, massificação e despolitização, no final desta década, quando novos personagens entraram em cena trouxeram consigo a marca da busca por autonomia, pela construção de um sujeito coletivo e pela contestação à ordem estabelecida.

O autor traz ainda importante contribuição ao afirmar que a existência de uma nova configuração social e de um novo sentido às condições de vida não são resultantes "naturalmente" do cotidiano popular e também não são decorrentes de discursos previamente estabelecidos. Elas constituem-se de reelaborações das experiências vividas em matrizes discursivas comuns. Nas palavras do autor:

\begin{abstract}
A potencialidade das novas matrizes está, portanto, tão ligada à consistência interna das suas categorias e modalidades de abordagem do vivido quanto à sua abertura, às fissuras que deixa para poder incorporar o novo, aquilo que era ainda indizivel e para o que não poderia necessariamente haver categorias feitas. (SADER, 1988, p. 143)
\end{abstract}

Dessa forma, o autor afirma a existência de três agências ou instituições em crise que irão reelaborar seu discurso, abrindo espaço para novas contribuições que visassem o cotidiano popular, sob uma ótica de luta contra as condições dadas.

Dentre essas três matrizes discursivas podemos citar, em primeiro lugar, a Igreja Católica, com a Teologia da Libertação, os Grupos de Juventude e as Comunidades Eclesiais de Base (CEBs). A partir, do final dos anos 1960, as CEBs se multiplicaram por todo o país e rapidamente ocuparam um lugar predominante nos movimentos sociais.

Um fator que explica a importância da Igreja neste período está ligado ao início da Ditadura Militar no Brasil e da intensa repressão após o golpe de 1964, que fizeram das CEBs um espaço livre do domínio do Estado (SADER, 
1988). Outro fator que explica a importância das CEBs está ligado às mudanças operadas no seio da própria Igreja Católica que passou a possuir "opção preferencial pelos pobres e pelas comunidades de base". (SACHS, 1999, p. 167)

Além da Igreja Católica, temos como segunda matriz discursiva o grupo dos marxistas de uma esquerda dispersa, formado por militantes operários e de formação intelectual, profissionais de diferentes formações (arquitetos, assistentes sociais, advogados, professoras, etc.). O grupo tinha em comum alguma ou nenhuma passagem por organizações revolucionárias e influenciados pelo marxismo, mantinham referências ideológicas básicas de oposição ao capitalismo e à exploração da classe operária, como formas de lutas. Assim, atuaram como "formadores de opinião" entre militantes de movimentos sociais. No entanto, estavam relegados a clandestinidade e por formarem uma esquerda dispersada, acabaram tendo suas teses absorvidas por programas revolucionários, que estavam desarticulados dos seus discursos de origem.

Ainda durante a década de 1970, temos o que o autor chamou de terceira matriz discursiva, composta pelo "sindicalismo autêntico" ou "novo sindicalismo", que se pretendia independente do Estado. Eram formados pelos "novos movimentos de bairro", que se constituíram num processo de auto-organização, reivindicando direitos e não trocando favores como os movimentos do passado. Esse movimento, determinado pela terceira matriz discursiva, ocasionou o surgimento de uma "nova sociabilidade" em associações comunitárias onde a solidariedade e a autoajuda se contrapunham aos valores da sociedade inclusiva; eram os "novos movimentos sociais, que politizavam espaços antes silenciados na esfera privada". (SADER, 1988, p. 35-36).

Desta forma, os movimentos sociais recorreram as matrizes discursivas para repensar a atualidade. Essas matrizes ora se mesclaram, ora se transformaram, conforme a ênfase requerida pelos grupos que as 
manipulavam. Assim, as duas últimas décadas do século XIX (1980 e 1990), foram marcadas por uma forte atuação dos movimentos sociais, enquanto novos sujeitos coletivos.

Diante deste quadro de efervescência política, em 1982, foi eleito Franco Montoro (1983-1987), como Governador do Estado de São Paulo, que propôs o desenvolvimento de políticas públicas populares através da descentralização política e democratização. Para tanto lançou, em 1984, o Programa Estadual de Mutirão e Autogestão, que foi um dos primeiros programas no estado de São Paulo a incorporar a ideia de "participação popular" como princípio básico. Este programa pode ser considerado o marco mais importante da CDHU ${ }^{15}$, pois manteve a atuação estatal em um período de crise do sistema federal e atingiu as faixas de renda mais baixas, a custos menores (já que terreno e infraestrutura não foram incidentes no valor total da habitação).

O governo de Orestes Quércia (1987-1991) rompeu com essa forma de atuação e instalou um modelo de produção em "massa" de unidades habitacionais. Aconteceram mudanças no conceito e na escala de produção. O modelo era uma tentativa de se diferenciar da gestão anterior e baseava-se na empreitada global ou subempreitada, onde a CDH faz o gerenciamento de construtoras. Foi nesta gestão que aconteceu a mudança de nome de CDH para CDHU.

Mas foi no ano de 1988, que aconteceu a conquista eleitoral de Luiza Erundina, política de esquerda do Partido dos Trabalhadores (PT), "uma senhora, solteira, migrante, nordestina e assistente social"16 (Figura 1), ganhou

\footnotetext{
15 Neste período, a CDHU ainda recebia a denominação de Companhia de Desenvolvimento Habitacional (CDH). No entanto, com finalidade de simplificação da compreensão do texto, ou seja, como processo metodológico, usaremos a sua denominação mais atual CDHU quando forem abordados de forma mais geral. Apenas nos itens 1.3 e 1.4 é que usaremos a terminologia adequada ao contexto.
}

16 Arantes (2010). 
as eleições municipais e provocou uma mudança na história do Brasil, sobretudo na história dos mutirões em São Paulo.

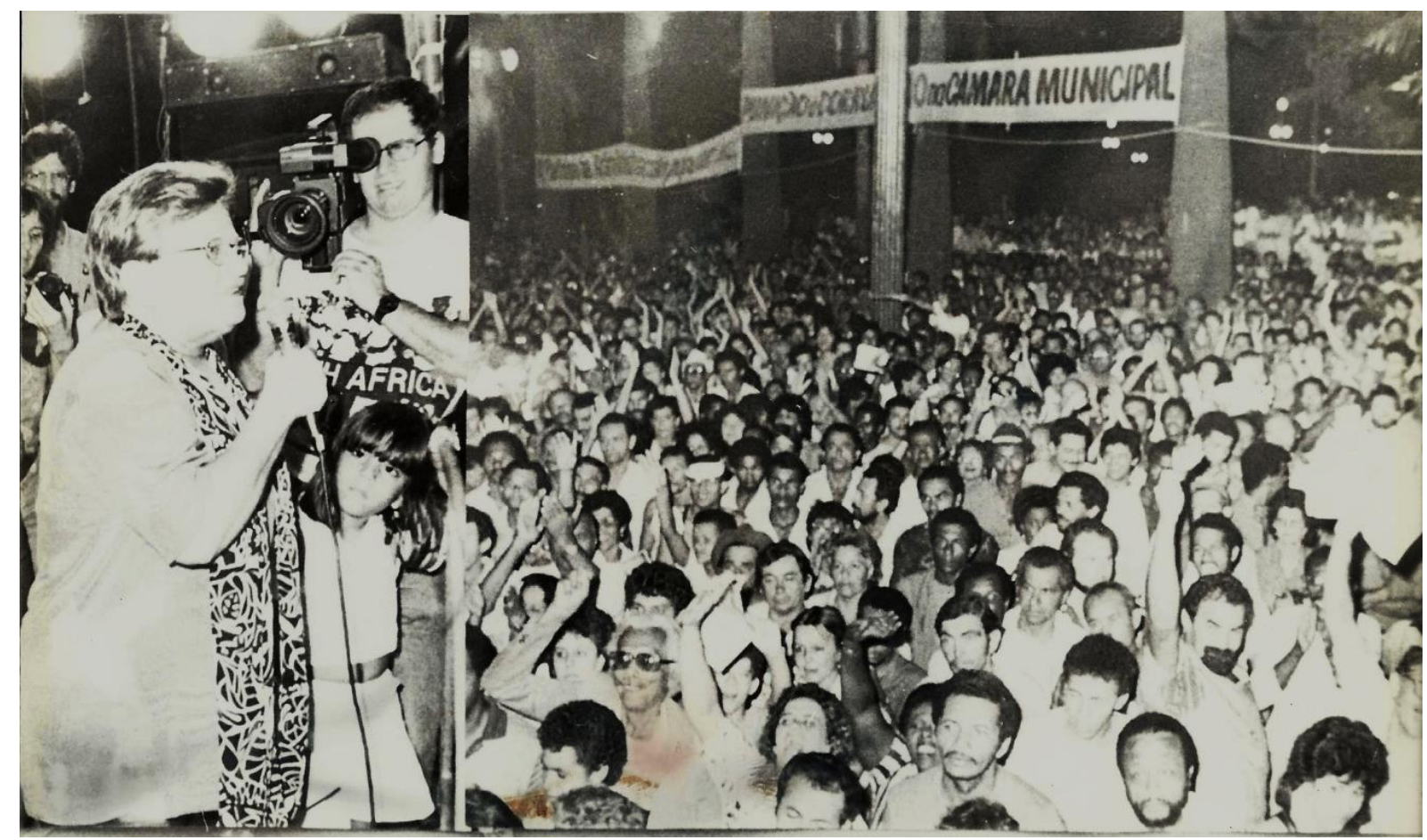

Figura 1| Luiza Erundina discursando em comício antes da conquista eleitoral em 1988. Fonte: Agenda da Prefeita, 2011

Foi na gestão de Erundina que a problemática habitacional apareceu como prioridade e a implantação habitação de interesse social por mutirão autogerido como uma das soluções para a redução das necessidades habitacionais.

Para alguns autores que estudam os mutirões, este período é considerado o auge da produção de habitação nesta modalidade, pois foi o momento em que mais se desenvolveram experiências como esta em todo o Estado de São Paulo, sobretudo na capital (Figura 2).

Conforme tendência em voga, todas as outras áreas de atuação pública, além da habitação, como educação e saúde foram pensadas a partir da organização por meio do mutirão autogestionário. 
RELAÇÃO DOS MUTIRÕES DA GRANDE SÃO PAULO Associação de Moradores

Un. Hab. em construção

Associação dos Sem Terra da Leste I 82

Associação de Construção por Mutirão Jd. São Francisco I 160

Associação de Construção por Mutirão Jd. São Francisco II 157

Associação de Construção por Mutirão Jd. São Francisco III 164

Associação de Construção por Mutirão Jd. São Francisco IV 159

Associação de Construção por Mutirão Jd. São Francisco V 161

Associação dos Moradores do Itaim Paulista e Adjacências 38

Associação Comunitária Lírios do Itaim 206

Associação dos Moradores do Jd. Miriam II 100

Associação dos Moradores do Conj. Hab. Baltazar Cisneiro 200

\begin{tabular}{|l|l|}
\hline Associação dos Moradores do Conj. Hab. Lapema & 170
\end{tabular}

Associação dos Moradores do Conj. Hab. Campanha Gaúcha 127

Associação dos Trabalhadores Sem Terra do Cond. Santa Marta 77

Associação dos Trabalhadores Sem Terra do Portal São Marcos 104

Associação dos Trabalhadores Sem Terra do Conj. Hab. Mov. Unido 176

\begin{tabular}{ll} 
Sociedade Amigos do Fase II & 200 \\
\hline
\end{tabular}

\begin{tabular}{|l|l|}
\hline Associação dos Sem Terra da Zona Leste & 37
\end{tabular}

Associação de Moradores da Vila Arco-Íris $\quad 88$

\begin{tabular}{|l|l|}
\hline Associação de Moradia 23 de Outubro & 107
\end{tabular}

\begin{tabular}{|l|l|}
\hline Povo em Ação e Unidos Venceremos & 194
\end{tabular}

Povo em Ação $\quad 200$

Associação de Constr. por Mutirão Pq. Residencial Pedra Bonita 172

Associação de Constr. por Mutirão Conj. Res. Vila Linda 131

Movimento Pela Moradia $4^{\circ}$ Centenário Terra, Casa, Paz 200

Associação Comunitária Barro Branco I $\quad 50$

Associação Comunitária Barro Branco II $\quad 50$

Associação Comunitária Barro Branco III $\quad 50$

Associação Comunitária Barro Branco IV 50

Associação Comunitária Vila Nova $\quad 50$

Associação de Constr. por Mutirão União do Povo 200

Associação de Constr. por Mutirão João de Barro 200

Associação de Constr. por Mutirão Juntos Venceremos 200

Associação de Constr. por Mutirão Chico Mendes 200

Associação Comunitária de Constr. por Mutirão Boa Esperança 106

Movimento Quero um Teto

Associação Comunitária de Constr. Comunitária Jd. Celeste 200

\begin{tabular}{|l|l|}
\hline Grupo por Moradia do Alto Riviera & 27
\end{tabular}

Associação de Constr. Comunitária Sudeste 150

Associação de Constr. por Mutirão Conj. Hab. Pôr do Sol 100

Associação dos Trabalhadores Sem Terra Conj. Paraíso 49

Cooperativa Habitacional Lírios do Vale 125

Cooperativa de Construção por Mutirão Remanescentes da Liberdade $\quad 125$

\begin{tabular}{|l|l}
\hline Associação Centro Comunitário Jd. Vista Alegre & 50
\end{tabular}

Associação de Construção Comunitária de Diadema 100

\begin{tabular}{|l|l|}
\hline Associação de Construção Comunitária Jd. Industrial & 50
\end{tabular}

Figura 2| Relação dos Mutirões da Grande São Paulo, 1991.

Fonte: Jornal da União dos Movimentos de Moradia Popular, Março de 1991. 
Neste contexto, o Mutirão Vila Nova Cachoeirinha é uma das experiências emblemáticas em termos de utilização de processo de autogestão com mutirão. A obra contou com financiamento do programa Fundo de Atendimento à População Moradora em Habitação Subnormal, FUNAPS-Comunitário, implantado, a partir de 1989, logo depois que Luiza Erundina assumiu a prefeitura do município 17. Cabe salientar, que neste período foram assinados, aproximadamente 10 mil convênios, com organizações populares para a construção de casas em regime de autogestão e mutirão.

A gestão Luíza Erundina (1989/92), na prefeitura do município de São Paulo, marcou o início de nova forma de trabalho, onde as assessorias técnicas eram consideradas parceiras municipais na implementação da política habitacional popular ${ }^{18}$. Conforme, podemos verificar em relato de liderança da UMM:

A partir do momento em que o Nabil Bonduki assumi lá a
superintendência da habitação, a secretaria municipal da
habitação no governo da Luiza Erundina, ele começa, acho que
desenvolver com mais intensidade essa questão da autogestão, e aí
acho que são em torno de 10 mil unidades que são feitas em
mutirão. O sucesso desses mutirões feitos a partir do financiamento
do município fortalece muito a luta do movimento. (Entrevista E, ex-
coordenador da UMM, entrevista à autora, ago. 2011).

De acordo com Bonduki (1992), o Laboratório de Habitação e Assentamentos Humanos (LAB-HAB), do Curso de Arquitetura e Urbanismo da Faculdade de Belas Artes de São Paulo, foi uma experiência pioneira de pesquisa e de assessoria técnica a comunidade e aos movimentos de moradia. Esse grupo transferiu-se para a Faculdade de Arquitetura e

\footnotetext{
17 Para maiores detalhes sobre o Mutirão Vila Nova Cachoerinha, ver Bonduki (1992).

${ }^{18}$ É preciso explicitar que, a inserção do Governo da Luíza Erundina no município de São Paulo, foi incorporada neste item do texto da dissertação, apesar do mesmo propor abordar a política do governo estadual e não municipal, devido à importância que possuiu para a história do país, bem como, para o desenvolvimento do trabalho dos arquitetos diretamente com as populações, por meio das assessorias técnicas prestadas aos mutirões autogeridos.
} 
Urbanismo da Universidade de São Paulo (FAU/USP) e depois para a Universidade Estadual de Campinas (UNICAMP).

O grupo que tinha como princípio à extensão universitária foi à periferia, onde vivem os trabalhadores para buscar construir soluções conjuntas para a cidade, particularmente voltadas para o atendimento das necessidades habitacionais. Esta experiência possibilitou o desenvolvimento de uma atividade inovadora de formação complementação para os estudantes de arquitetura e urbanismo.

A Assessoria Técnica USINA - CTAH Centro de Trabalhos para 0 Ambiente Habitado ${ }^{19}$ nasce nos anos 1980 decorrente de experiências desse grupo de extensão universitária. A forma de trabalho da Usina suscita um repensar as suas hierarquias no processo de produção da habitação - tanto em termos de projeto arquitetônico como de política social. Além disso, visa ampliar os espaços de comunicação entre técnicos e população por meio do desenvolvimento de ferramentas para facilitar a compreensão dos mecanismos que regem o processo produtivo, cujos detalhes foram aprofundados no capítulo 3.

Conforme Arantes (2007), esta forma de trabalho das Assessorias Técnicas compôs um momento histórico importante de inversão do paradigma clássico do arquiteto do Partido Comunista Brasileiro (PCB), que trabalha para o Estado, produzindo, por exemplo, grandes conjuntos habitacionais, construídos por grandes construtoras pertencentes à população brasileira de alta de renda.

Desta forma, este momento marca uma grande alteração no papel do arquiteto, alguns desses grupos de profissionais deixaram de projetar para - Estado e foram trabalhar diretamente com os movimentos sociais, sobretudo com os de luta por moradia. Esse posicionamento, dos arquitetos é narrado como:

19 Para saber mais sobre a USINA, consultar: www.usinactah.org.br/ 
no que diz respeito à responsabilidade que um arquiteto formado deve assumir no contexto social em que vive. Não é um problema de mercado. Nós não estamos tratando o fazer arquitetura como mercadoria, mas estamos pensando nele como parte do desenvolvimento, como uma visão de mundo, como parte da contribuição que nós podemos dar para um mundo melhor. (Entrevista, Flávio Lefèvre, janeiro de 2010)

Assim, podemos afirmar que a produção intelectual de determinados arquitetos passou a abranger dimensões mais amplas, de transformação do instituído, conforme as ferramentas que a profissão lhes oferecia. Desta forma, esse grupo de arquitetos passou a atuar para além do projeto arquitetônico, buscando abranger aspectos mais amplos do processo de produção da habitação popular, proporcionado assim, maior democratização da arquitetura para este segmento.

Dentro deste contexto de surgimento de novos personagens, também podemos destacar a atuação do grupo Arquitetura Nova, composto por Sérgio Ferro20, Rodrigo Lefèvre e Flávio Império. Como o próprio nome já diz, eles propunham uma nova forma de produção da arquitetura, por meio da sua democratização e da desmistificação do processo de projeto e do trabalho no canteiro ${ }^{21}$.

As mudanças que estavam ocorrendo no papel do arquiteto deve-se a "uma espécie de caleidoscópio das ideias que aquele tempo incubava, para a construção de uma outra possibilidade de relação entre política e ofício"22, compondo um marco para a história da arquitetura brasileira e também para a história política do país.

\footnotetext{
20 No livro O Canteiro e o Desenho, Ferro (1982) faz uma critica ao projeto arquitetônico e suas relações com o canteiro. $O$ autor desmistifica as relações existentes entre o conceber $e$ o construir e afirma que a forma é também como manifestação da vida interna das coisas e das relações de produção. (grifo nosso)

${ }^{21}$ Arantes (2002) afirma que as origens do pensamento crítico sobre a produção arquitetônica moderna, teve papel central na figura do arquiteto Vilanova Artigas e de seus discípulos, os arquitetos do Grupo Arquitetura Nova. Para o autor, este grupo fez um redirecionamento do pensamento crítico de Artigas. Arantes analisa as discussões do grupo e seus desdobramentos, como questão central no mutirão autogerido.
}

22 LOPES $(2011$, P. 5). 
Em especial, cabe destacar a influência que a gestão municipal da Erundina causou no Governo do Estado, forçando-o a começar a planejar programas como de mutirão autogerido.

Desta forma, durante o governo de Fleury (1991-1994), percebemos uma atuação marcada predominantemente pela adoção de medidas baseadas no modelo de administração da questão habitacional instalado na gestão de Quércia. Podemos citar como fato que comprova esta tendência o lançamento do Programa Chamamento Empresarial. No entanto, também foi implantado o Programa de Mutirões. O primeiro obteve recursos financeiros vultosos e o segundo ficou relegado a uma modesta representação.

É importante destacar, que o lançamento do Programa de Mutirões será abordado no capítulo 2. Contudo, podemos apontar para uma mudança de paradigma do Governo Fleury, ou seja, seu governo não deu prioridade à ideia de participação popular que estava sendo construída e redirecionou sua política para uma atuação mais empresarial. Além disso, devemos investigar qual $\bigcirc$ sentido político da participação popular postulada pelo programa e em que medida esta participação de fato aconteceu no MUJ.

No decorrer deste processo, mais especificamente em 1991, organizações e movimentos populares urbanos filiadas ao Fórum Nacional de Reforma Urbana (FNRU) apresentaram ao Congresso Nacional o primeiro Projeto de Lei de Iniciativa Popular ${ }^{23}$ com a proposta de criação do Fundo Nacional de Habitação de Interesse Social (FNHIS) e do Sistema Nacional de Habitação de Interesse Social (SNHIS).

Esta iniciativa popular representou um momento de sistematização das reivindicações do FNRU e foi reconhecida como uma conquista dos

23 A iniciativa popular está prevista na Constituição de 1988 como uma das formas de exercício da soberania popular. 
movimentos sociais enquanto sujeitos políticos que organizaram uma ampla mobilização resultante no recolhimento de cerca de um milhão de assinaturas em todo o país. Em 19 de novembro de 1991, as assinaturas foram levadas ao Congresso Nacional na $3^{a}$ Caravana dos Movimentos de Moradia à Brasília, que contou com aproximadamente 5.000 pessoas (Figura 3).

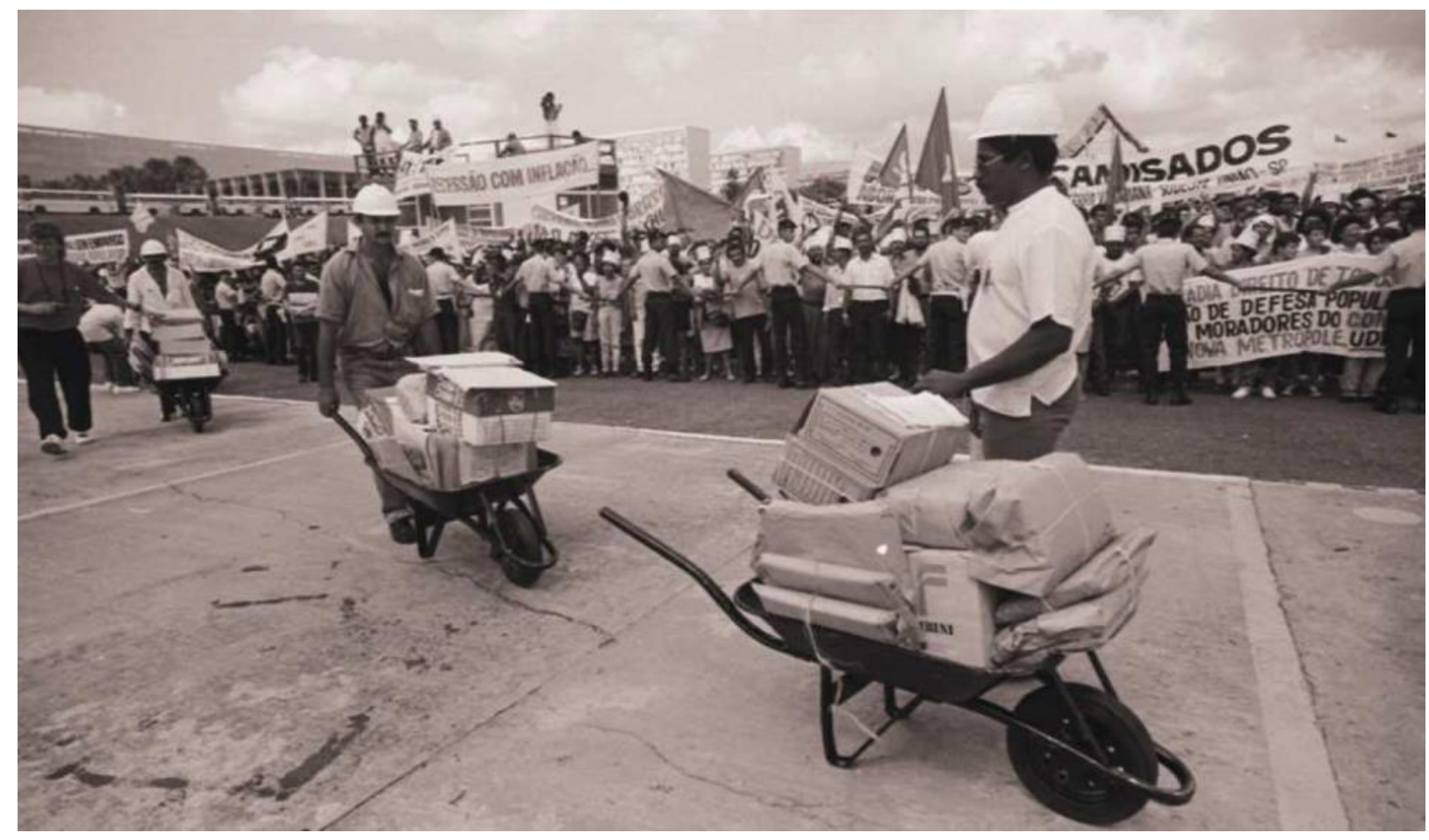

Figura 3 $3^{a}$ Caravana à Brasília, entrega de assinaturas do Projeto de Lei de Moradia Popular, 19/11/1991.

Fonte: 20 anos do Fundo Nacional de Moradia Popular, União Nacional, Abril 2012.

O FNRU possuía três eixos temáticos: 1) Direito a Cidades e a Cidadania; 2) Função social da cidade e da propriedade; 3) Gestão democrática das cidades, por meio da consolidação do orçamento participativo. O exemplo do FNRU é emblemático como forma de participação popular atuante na busca pela formulação de projetos para a moradia e para a cidade, também é demonstrativo do período de 
efervescência pela qual passava o país e, sobretudo para mostrar os desejos das organizações sociais em promover uma transformação social profunda 24 .

Ainda neste sentido, também podemos citar como exemplo representativo desse momento de grande força para a transformação social, o depoimento de morador do Mutirão União da Juta, contando das motivações, das esperanças e das vontades iniciais que eles possuíam de transformar a realidade do país. Este relato demonstra a ação e força política que os movimentos sociais tinham neste contexto:

\begin{abstract}
Nosso objetivo era mudar esse país. Então a grande motivação que naquela época, hoje não é tanto mais, porque a gente viu muitas coisas e deixou de acreditar em algumas coisas também. A gente acredita ainda, mas deixou de acreditar em algumas coisas. Mas naquele período, era o período em que você estava na ditadura militar, que você tinha o inimigo na sua frente, você sabia quem era o inimigo e você podia ir pra cima do inimigo. Então, o que motivava muito a gente era isso, era sonhar com um outro país, com um outro mundo. Fazer essas lutas. Fazer ocupações, greves. Entendeu? Em todo lugar que você ia tinha convergência pra essa luta, por essa causa. Então, o que me motivou e me animou muito a entrar nessa Iuta naquela época e que eu não saí mais até hoje foi isso. É claro que de lá pra cá a gente já viu, o Lula já foi presidente né. Muitas coisas mudaram. As mulheres hoje estão no poder, né. E muito pouco mudou né, mas mudou algumas coisas. (Entrevistado B, MUJ, entrevista à autora, ago. 2010).
\end{abstract}

Em 1994, o então candidato a governador de São Paulo, Mário Covas, realizou campanha eleitoral comprometendo-se a elaborar um programa de mutirão com autogestão. Intitulava-se o "pai dos mutirões", entretanto, já no primeiro ano do Governo Covas (1995-2001) foram paralisadas todas as obras por mutirão que estavam em andamento com menos de $20 \%$ de seu cronograma físico-financeiro realizado. Tendo em vista compreender os problemas no andamento dos mutirões, a CDHU estabeleceu parceria com a Fundação Getúlio Vargas (FGV), para tentar adaptar a visão administrativa gerencial em substituição à estrutura burocrática anterior.

\footnotetext{
${ }^{24}$ Apesar de toda essa mobilização e pressão popular, o FNHIS e o SNHIS só foram aprovados em 2004 e sancionados, durante o Governo Lula, em 2005.
} 
Em maio de 1995, após um processo de negociação entre a CDHU e os movimentos de moradia, começou-se a elaborar o Programa Paulista de Mutirão e Autogestão que, de certa forma, representou uma continuação do Programa de Mutirão da União dos Movimentos de Moradia (PM/UMM). A criação deste novo programa possibilitou a incorporação das reivindicações de outros movimentos sociais por moradia. No capítulo 2 , buscamos compreender estes programas em detalhes, sobretudo, no que se refere às alterações ocorridas no seu formato e caráter.

Desta forma, o contexto político em que se insere o Mutirão União da Juta é resultado de um quadro de intensas pressões dos movimentos de moradia, a partir da década de 1980, tanto nos governos estaduais como nos municipais. A partir das eleições municipais, deu-se início a Gestão Paulo Maluf, que redirecionou suas políticas, paralisou os mutirões da Gestão Erundina, fazendo com que parte da força dos movimentos populares fosse canalizada para os Governos Estaduais, obrigando-os a dar uma resposta às demandas dos movimentos.

O contexto histórico e político do MUJ, também se insere em um momento de ampliação dos espaços de participação. Cabe investigar como esta participação aconteceu de fato. A hipótese que se coloca é que no MUJ as relações entre Governo e População, foram alteradas em decorrência de uma forte capacidade organizativa dos mutirantes. De tal modo, que nos permite distinguir diferentes níveis de participação popular.

Diante do exposto, o desafio que se impõe é entender quais os conflitos e disputas que estavam em jogo no MUJ que justificam as alterações nos níveis de participação popular e consequente formas de relação com os entes públicos menos formalizadas. Em 24 de junho de 1992 foi assinado o contrato para a construção por mutirão com autogestão da Vila União da Juta (no capítulo 3 são apresentados os detalhes deste Mutirão). 
Podemos perceber que a atuação do Poder Público caminhou no sentido de criar programas habitacionais e não conseguiu criar políticas verdadeiramente amplas com vistas à universalização dos direitos à moradia. Assim sendo, cabe avançar nas discussões sobre o principal órgão público que coloca em execução esses políticas alternativas, a CDHU, para depois proceder à análise específica do programa de mutirão (capítulo 2).

\subsection{Evolução institucional da CDHU: de CECAP à CDH}

A fim de compreendermos o contexto em que ocorreu 0 financiamento do Mutirão União da Juta (MUJ), nosso objeto de estudo, apresentamos neste item a constituição institucional e atuação da CDHU nos programas de mutirão e autogestão no município de São Paulo. A apreensão das características da ação desta Companhia como agente promotor e financeiro em tais programas nos permitirá contrapor com as especificidades (apresentadas no Capítulo 3) da experiência do MUJ.

Para melhor compreensão da evolução institucional deste órgão ligado ao poder público, iniciamos a temática com a Caixa Estadual de Casas para o Povo (CECAP), surgida no bojo de um processo de descentralização, até chegar ao que é hoje a Companhia de Desenvolvimento Habitacional e Urbano do Estado de São Paulo (CDHU). Na sequência, abordaremos sua evolução institucional - de agência de financiamento a uma moderna empresa, autonomizada - e a sua controversa concepção de provisão pública de habitação.

Com a crise do Sistema Financeiro de Habitação (SFH), implantado em 1964, no início da ditadura militar, os estados da Federação vão gradualmente recebendo maior autonomia para responder as necessidades habitacionais cada vez mais prementes.

Em 10 de outubro de 1949, o governador Adhemar de Barros criou por meio da Lei n. ${ }^{\circ}$ 483, o primeiro órgão no estado destinado à questão 
habitacional: a Caixa Econômica de Casas para o Povo (CECAP). A autarquia funcionava junto à Secretaria de Trabalho, Indústria e Comércio e possuía estrutura de administração indireta. Conforme Bonduki (2004), o governador aspirava enfrentar a forte crise habitacional e manter-se "de olho nos dividendos políticos" (p. 122). Mesmo que para isso a CECAP permanecesse "inoperante durante seus primeiros tempos de existência" (Idem, p.122). As primeiras unidades habitacionais foram realizadas apenas em 1967, a partir da lógica centralizada do SFH. O artigo 23 da Lei n 483 que institui a CECAP versa sobre a tendência deste órgão a elaborar projetos padronizados de "Casas Para o Povo", mostrando que esta postura é historicamente assumida pelo poder público com certa naturalidade.

Em 1975, a lei $n^{\circ}$ 905, transformou a CECAP autarquia em Companhia Estadual de Casas Populares (CECAP), agora já como uma empresa pública e sociedade de economia mista que atua como agente financeiro e promotor do Plano Nacional de Habitação Popular (PLANHAP). A CECAP passou a possuir diretoria profissionalizada, conselho de administração e conselho fiscal, contabilidade e corpo de funcionários próprios. Com a mudança para sociedade de economia mista, a principal alteração se deu com a possibilidade de escapar do rígido controle do Direito Público, operando com instrumentos típicos do Direito Privado25.

A referida Companhia produziu cerca de quatorze mil unidades habitacionais, sendo que a maior parte delas foi realizada no interior do estado. Uma das principais realizações da CECAP é o Conjunto Habitacional Zezinho Magalhães Prado, em Guarulhos/SP, popularmente chamado de Conjunto CECAP - Cumbica. O projeto do conjunto foi elaborado, em 1967, pelos arquitetos João Batista Vilanova Artigas, Fábio Penteado e Paulo Mendes da Rocha, com intuito de transformar-se em um modelo de política habitacional estadual.

25 Royer (2002). 
O desejo dos arquitetos com este projeto era industrializar o processo de execução do conjunto. A implantação linear dos blocos dos edifícios sobre pilotis, conformados em fitas, com previsão de áreas de uso misto para instalação de um comércio local, assemelha-se as superquadras do urbanismo preconizado por Le Corbusier (Figura 4). Em linhas gerais, esse projeto representa a construção de grandes conjuntos habitacionais pertencentes ao projeto moderno de cidade, tendência predominante na década de 1970. Além disso, Arantes (2007, p. 42), embasado por Ferro (1966), afirma que esta arquitetura moderna significava a "posição progressista que o país adotara" e direcionava-se na contra mão daquilo que Sérgio Ferro postulava como uma reintegração entre trabalho manual e intelectual - temática, que de certa forma, será aplicada no Mutirão da União da Juta.

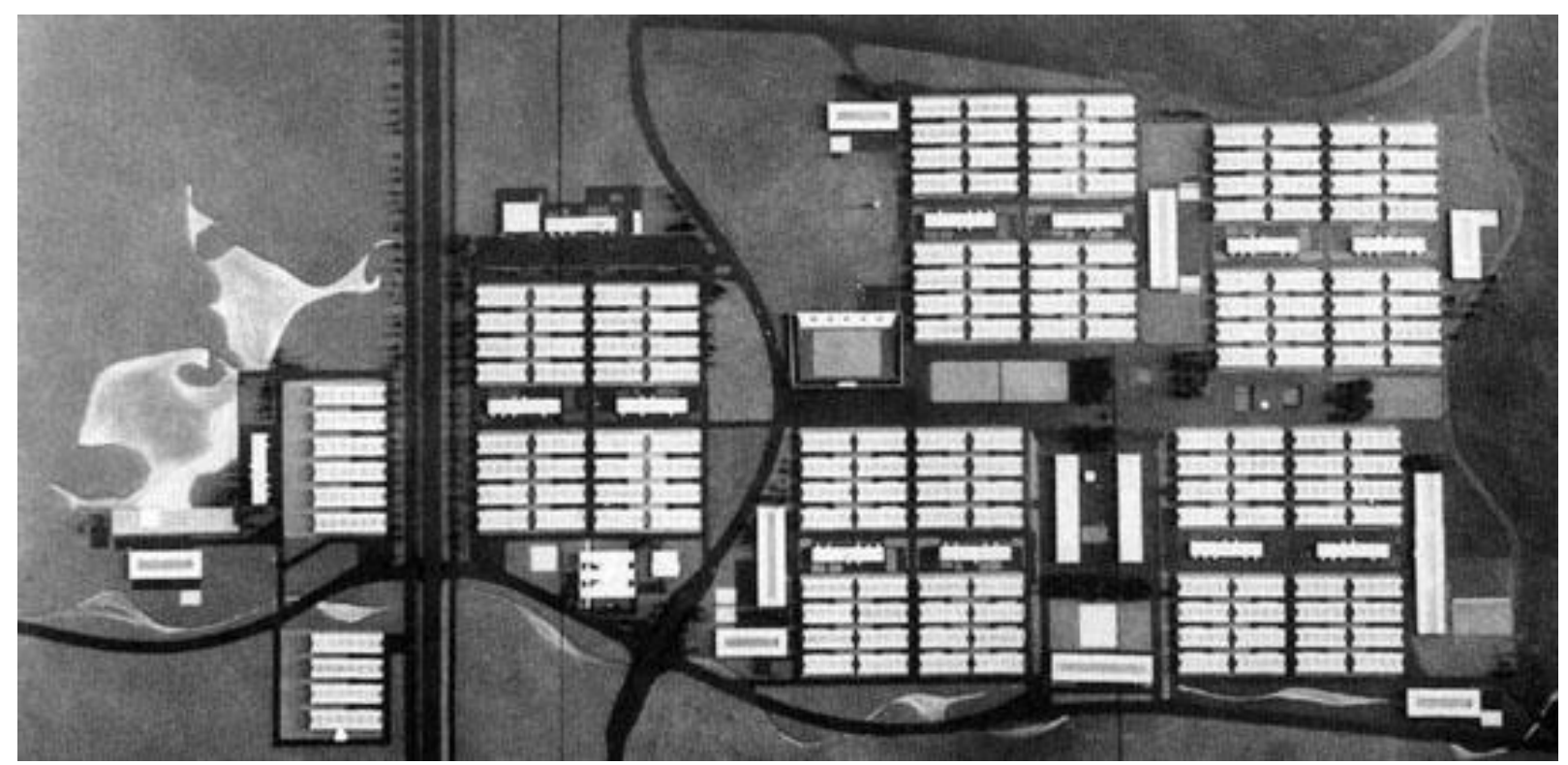

Figura 4| Implantação do Conjunto Habitacional Zezinho Magalhães Prado, o projeto original previa cerca de 11.000 unidades habitacionais, mas foram executadas 4.680 habitações.

Fonte: Revista Desenho n. 5, 1973.

Em 1981, no Governo de Paulo Maluf, a CECAP recebeu a denominação de Companhia de Desenvolvimento de São Paulo 
(CODESPAULO)26, mas a estrutura operacional manteve-se semelhança a anterior. Durante esta gestão, a empresa estabeleceu como metas promover a desconcentração do desenvolvimento urbano e a indução do desenvolvimento regional, por meio da implantação do programa do Governo Federal - PROMORAR.

Com a Nova República, em 1984, a CODESPAULO foi transformada em Companhia de Desenvolvimento Habitacional (CDH) e passou por uma reforma geral dos quadros, pois com a crise do SFH houve um intenso aumento da inadimplência na Companhia, que quase determinou o seu fechamento por dívidas. Dessa forma, o Governo do Estado, buscou estabelecer um dispositivo próprio de intervenção nos problemas habitacionais promovendo alterações nas regras de financiamento. O novo modelo da CDH passou a descentralizar e mobilizar os municípios para operar nos programas habitacionais com recursos do tesouro estadual.

Neste sentido, é importante perceber que a forma de atuação da CDHU é circunstancial, apesar de não possuir grandes mudanças estruturais, a Companhia foi se adaptando e se adequando enquanto operadora de um sistema de produção habitacional público.

No final da década de 1980, foram criados mecanismos para a reabilitação da CDHU no Estado de São Paulo. Pretendia-se viabilizar um fluxo contínuo de recursos financeiros e assegurar uma oferta constante de programas de habitação social. Entretanto, Royer (2002) afirma que a descentralização proposta como uma "panaceia" não teria força em si mesma para garantir a democratização e participação popular, resultando em novas alterações na estrutura da empresa no sentido de aperfeiçoar seu "modus operandi" para atingir, pelo menos em parte, a demanda habitacional.

${ }^{26}$ Cf. Royer (2002), o governador Paulo Maluf alterou no nome da empresa, "para que em mais um dos órgãos públicos figurasse o seu nome, 'Paulo'". 


\subsection{A CDHU como agente promotora e financeira}

Para a constituição da CDHU, como agente promotora e financeira de políticas de habitação popular, foram realizadas mudanças significativas na distribuição de recursos tributários nas três esferas públicas, com forte descentralização das fontes de tributos. Desta forma, criaram-se as bases para a dinamização da política no Estado: 1) interesse político; 2) fonte de recursos volumosa e estável; e 3) estrutura institucional consolidada.

O modelo era uma tentativa de se diferenciar da gestão anterior, tanto no conceito da empresa, como na escala de produção, e baseava-se na empreitada global ou subempreitada, onde a CDH faz o gerenciamento de construtoras. Foi na gestão de Orestes Quércia (1987-1991) que aconteceu a mudança de nome de CDH para Companhia de Desenvolvimento Habitacional e Urbano (CDHU).

Desta maneira, no final dos anos 1990, foi instaurado um "divisor de águas" entre as formas de promoção pública no Governo do Estado. Enquanto o governo anterior caminhou no sentido de democratizar e ampliar as formas de participação, o governo Quércia seguiu no sentido oposto implantando uma forma de política que visava à redução de déficit habitacional, a produção em massa e a dinamização do setor da construção civil.

O Conjunto Águia de Haia foi construído pela CDHU em 1988. A execução do conjunto foi dividida em duas etapas de obra, que ao final totalizaram mais de 1000 unidades habitacionais. O conjunto localiza-se no bairro Cidade Antônio Estêvão de Carvalho, no extremo da zona leste e pertence ao município de São Paulo.

Este Conjunto habitacional foi conquistado por meio de inúmeras reivindicações do movimento de moradia ligado ao Movimento dos Trabalhadores Sem-Terra de Ermelino Matarazzo (MST). 
As casas foram entregues sem nenhum acabamento, entre uma casa e outra não havia limites e os quintais com os seus varais de roupas eram os espaços de todos e de ninguém ao mesmo tempo, como pode ser observado na Figura 5.

Este novo modelo resulta em um novo padrão de qualidade - redução da área construída, menos precisão nos acabamentos e nas paredes internas, pisos de solo cimento e ausência de forro. No caso do Conjunto Águia de Haia, não foram definidos os parcelamentos do solo e os limites entre as casas.
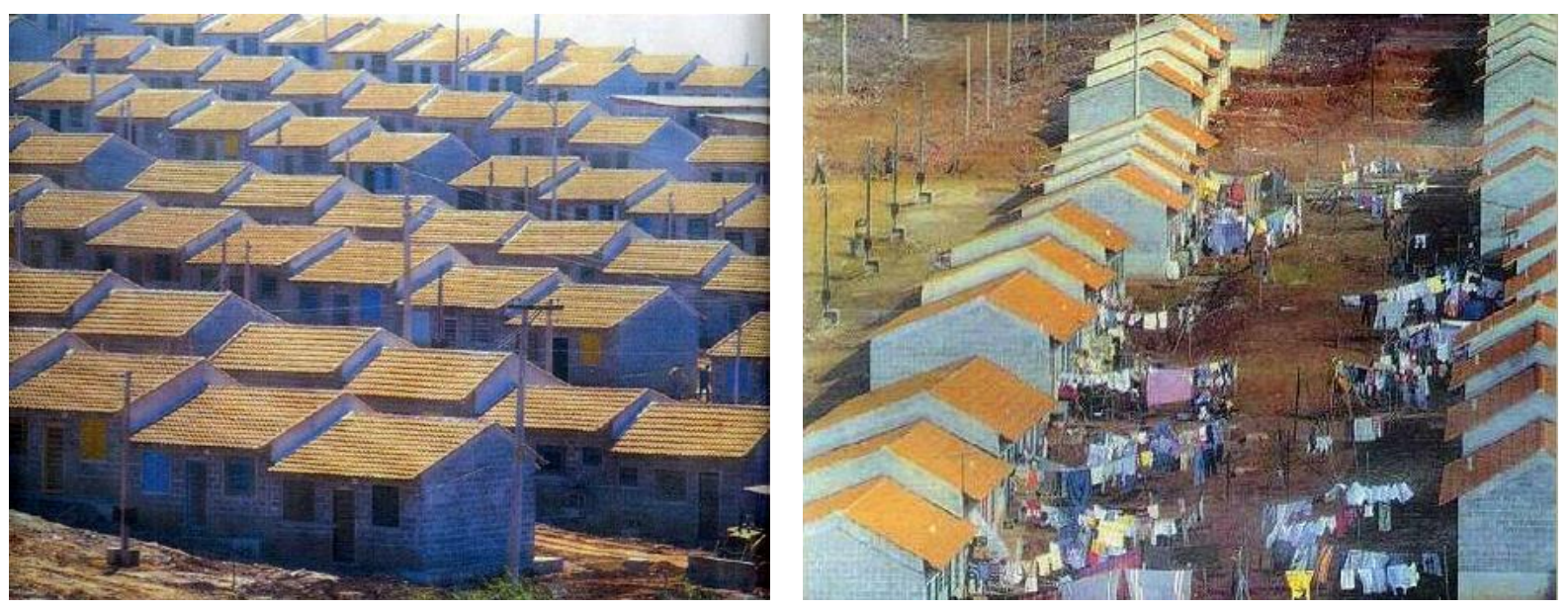

Figura 5 | Conjunto Habitacional Águia de Haia, município de São Paulo. Fonte: http://conjuntoaguiadehaia.webnode.com.br/

O Conjunto Águia de Haia apresenta-se como uma aplicação de produção do tipo convencional historicamente estabelecida. Por outro lado, a Vila União da Juta, apesar de também possuir localização períferica, se apresenta como contraponto, tanto para essa forma de produção convencional, quanto ao fator relacionado à qualidade arquitetônica.

Desta forma, a análise da atuação da CDHU nos remete a seguinte questão: É possível construir conjuntos habitacionais de uma outra maneira? Consideramos que a implantação de um programa que tenha como princípio a participação, a autogestão, o desenvolvimento de inovações tecnológicas e geração de oportunidades de trabalho e renda é 
fundamental como resposta mais adequada para o problema da moradia popular.

Alguns destes princípios foram incorporados no Programa Paulista de Mutirões, cujos detalhes podem ser observados no Capítulo 2. Cabe investigar qual o real sentido que os mesmos apresentaram e quais desses princípios foram de fato incorporados no Mutirão União da Juta, para que assim, possamos afirmar se o mesmo é um caso emblemático de mutirão com autogestão e com qualidade arquitetônica.

É importante salientar que não queremos produzir um "manual de produção de moradia popular", menos ainda, afirmar a reprodução desse modelo de Mutirão a ser seguido com fins de universalização do direito a moradia. Entendemos que a União da Juta faz parte de um contexto histórico-político específico de produção habitacional que já se realizou enquanto tal e a sua reprodução descontextualizada pode gerar distorções e equívocos de toda ordem.

Portanto, neste trabalho enfatizamos a modalidade de produção de moradia popular por mutirão autogerido, que resultou na Vila União da Juta (nosso objeto de estudo). Neste sentido, consideramos relevante a avaliação do programa que deu origem a esse empreendimento específico, conforme apresentamos no Capítulo 2 a seguir. 


\section{CAPITULO 2 \\ UM MODO DE PRODUZIR MORADIA: DO PROGRAMA MUTIRÃO UMM AO PROGRAMA PAULISTA DE MUTIRÃO}

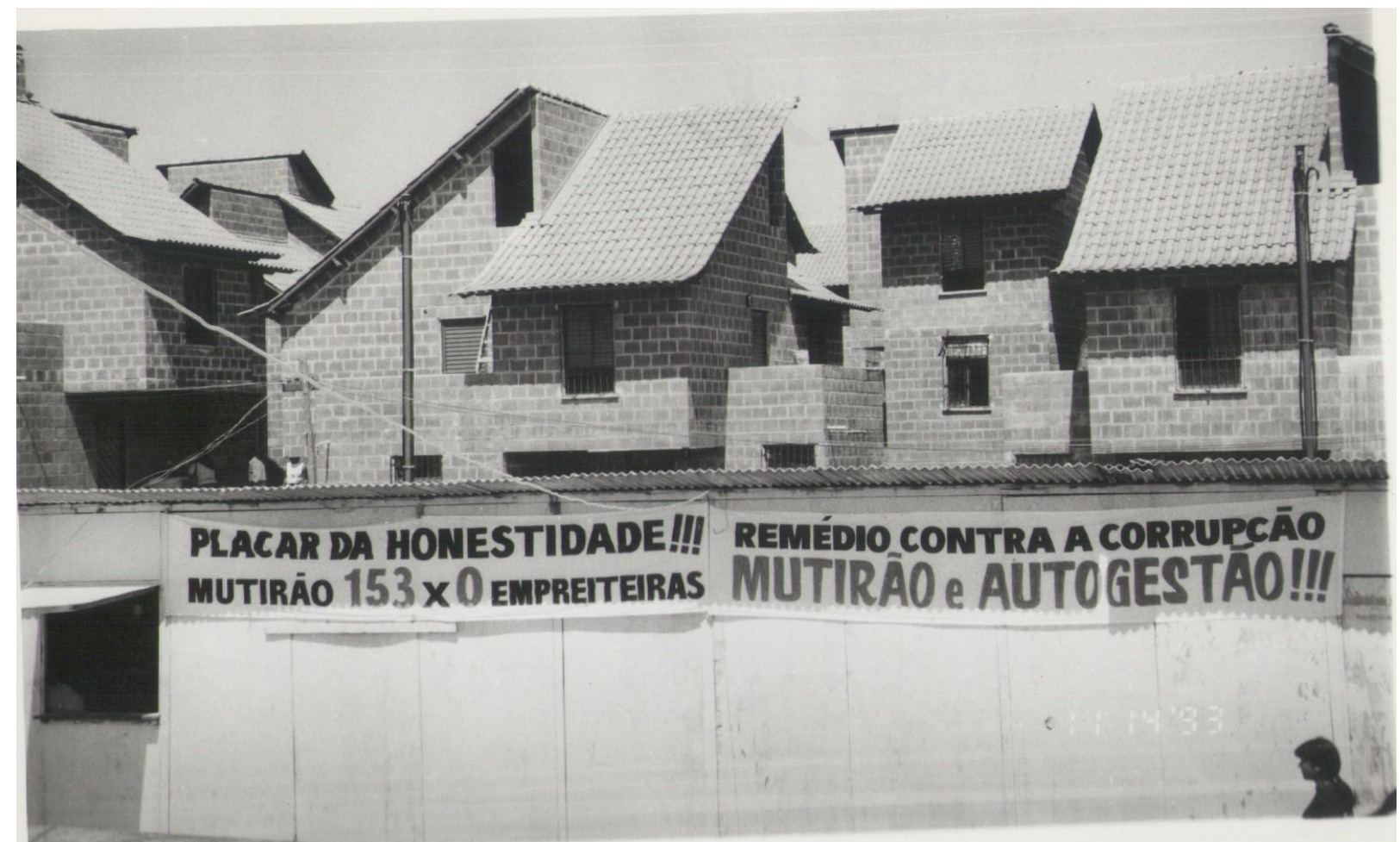

Fonte: http://cidadeaberta.org.br 


\section{CAPÍTULO 2 |UM MODO DE PRODUZIR MORADIA: DO PROGRAMA MUTIRÃO UMM AO PROGRAMA PAULISTA DE MUTIRÃO}

No primeiro capítulo realizamos uma contextualização sobre a atuação do Estado no desenvolvimento de programas de habitação popular e apresentamos a ampliação da estrutura institucional da CDHU, agente responsável pela promoção e financiamento destes programas.

Este capítulo tem como objetivo complementar o histórico institucional da CDHU, por meio da análise do Programa Mutirão União dos Movimentos de Moradia (PM/UMM) que depois passou a ser denominado Programa Paulista de Mutirões (PPM). A criação destes programas acompanhou a tendência em voga de promover a construção de habitação por meio de mutirão. Como apontado no capítulo 1, o Governo Federal já havia realizado propostas neste sentido, que influenciaram o desenvolvimento destes programas em âmbito estadual.

A escolha do Programa Mutirão União dos Movimentos de Moradia (PM/UMM) e, da sua versão atualizada, o Programa Paulista de Mutirões (PPM), como objetos de análise deve-se a importância que possuíram no contexto histórico-político, sobretudo por estar pautado na modalidade de construção por mutirões autogeridos, que vinham acontecendo, principalmente em São Paulo e que embasaram o desenvolvimento das propostas do PM/UMM . Além disso, a elaboração e implementação destes programas, foi marcada por inúmeros embates que influenciaram diretamente no desenvolvimento do Mutirão União da Juta (MUJ).

Portanto, procuramos compreender quais foram os principais embates e conflitos entre os sujeitos sociais atuantes nesse processo que determinaram o sentido autogestionário existente nestes programas. Por fim, no terceiro capítulo analisamos um modelo de aplicação prática do PPM: a experiência do Mutirão União da Juta. 


\subsection{Origens da modalidade de produção}

O Programa Mutirão União dos Movimentos de Moradia (PM/UMM) nasce como fruto de um contexto histórico-político muito específico e determinante para a sua criação como programa habitacional destinado a atender prioritariamente a população com faixa de renda até 5 salários mínimos. Como apontado anteriormente, existia um conjunto de possibilidades que motivaram o Governo Estadual a um posicionamento no sentido de desenvolver um programa habitacional tomando o mutirão como pressuposto.

Em síntese, dentro de um contexto nacional, essas motivações possuíam razões distintas: do ponto de vista econômico, o país vivia um período paradoxal de amplo desenvolvimento econômico e modernização, sobretudo na década de 1970, mas que por outro lado, teve como consequência, um processo social perverso, de arrocho salarial, empregos precários, desempregos, etc. Do ponto de vista político, esse paradoxo se traduz em maior visibilidade para a crise pela qual passava o processo de redemocratização brasileiro e maior vitalidade para os movimentos de luta por moradia.

Em um contexto local, a cidade de São Paulo, uma das principais capitais do país, passava por um processo de crescimento urbano desenfreado marcado por uma produção do espaço socialmente segregado e por sérios problemas ligados à moradia popular (ocupações irregulares, cortiços e subhabitações). Como (re)ação a esse processo, aumentaram-se as pressões sobre o governo do Estado, motivadas pela conjuntura nacional, pelo término da gestão Erundina e pelas influências deixadas por esta gestão com a implantação do programa FUNAPSComunitário. Desta forma, estas pressões direcionavam-se para o desenvolvimento de um programa baseado no mutirão com autogestão em âmbito estadual. 
A experiência anterior da CDHU com programas de mutirão se deu através do Programa Municipal de Habitação (PMH), implantado na Gestão Montoro (1983-1987), fato que poderia indicar alguma familiaridade com a temática. No entanto, o PMH baseava-se no mutirão como modalidade de construção, mas não incorporava elementos da autogestão. Em vista disso, o processo de elaboração do programa alterou as rotinas da companhia, pois a mesma viu-se obrigada a se adaptar as novas demandas inerentes ao processo de produção por mutirão - modalidade defendida pela UMM e pelas assessorias técnicas, sujeitos que, até então, não faziam parte das práticas da CDHU.

Ainda neste sentido, no PMH a prefeitura era o agente de orientação e de assessoria. Já no Programa Paulista de Mutirão (PPM), os movimentos requisitavam a escolha de uma assessoria técnica própria que elaboraria o projeto arquitetônico próprio.

Além disso, este contexto de elaboração do programa diferenciava-se da conjuntura de implantação do PMH. Neste período os movimentos sociais encontravam-se fortalecidos e já tinham outras demandas, mais complexas, como por exemplo, a incorporação da autogestão. Este elemento poderia alterar totalmente o caráter do programa.

Estes fatos indicam que apesar da CDHU ter certa experiência com programa de mutirão, a elaboração do PPM, indica novas demandas, que resultariam em um programa diferenciado, com vistas à autogestão. A seguir, no item 2.2, apresentamos as características desse do PPM que nos permitem identifica-los como tal.

Neste sentido, a União dos Movimentos de Moradia da Grande São Paulo (UMM-SP) foi um importante sujeito deste período, pois desempenhou - papel de grande articulador entre o conjunto dos movimentos sociais, assessorias técnicas, Igreja Católica e sindicatos (as influências deixadas por 
esses atores sociais no desenvolvimento do Mutirão União da Juta serão abordadas no capítulo 3).

A UMM ainda possuiu importante colaboração na proposta de criação do programa, enquanto sujeito representativo das reivindicações populares. A grande influência deste movimento também pode ser percebida devido à inserção do próprio nome do movimento (UMM) no nome do programa: Programa Mutirão UMM (PM/UMM)27.

Assim, o PM/UMM começou a ser pensado e discutido, a partir de agosto de 1991, quando o Governador do Estado, Luiz Antônio Fleury Filho (1991-1995) comprometeu-se com a construção de 3.040 unidades habitacionais na primeira etapa de implementação do programa ${ }^{28}$. Em 1993, é firmado novo compromisso de construção de mais 3.000 mil unidades durante a segunda fase de execução do Programa.

Na sequência, o Governo Covas (1995-2001) lança o PM/UMM, com compromisso de efetuar a construção de mais 6.000 unidades habitacionais. Segundo Royer (2002), esse programa tem seu nome alterado para Programa Paulista de Mutirão (PPM), a razão para essa mudança de nome, deve-se a ampliação do atendimento a outros movimentos sociais, além da UMM, que estavam surgindo em São Paulo, como a Central de Movimentos Populares (CMP) e o Movimento Nacional de Lutas por Moradia (MNLM). Conforme a autora, as prioridades deste governo foram o estímulo à organização popular para a finalização das construções e redução dos custos e prazos de produção. Na verdade, o intuito era "diferençar-se da gestão anterior e imprimir a marca do governador à sua formulação" (ROYER, 2002, p. 382).

\footnotetext{
27 Pessina (1997).

28 Conforme Royer (2002), as unidades habitacionais seriam distribuídas da seguinte maneira: 960 em terrenos do patrimônio da CDHU, 960 terrenos doados pela prefeitura de São Paulo, 160 em terrenos das associações e 960 em terrenos em outras prefeituras.
} 


\subsection{Os objetivos e características da modalidade de produção}

O Manual do Programa Paulista de Mutirões (PPM), afirma que um dos objetivos do programa era "ampliar a oferta de moradias, implantando conjuntos habitacionais dotados de infraestrutura"29. Durante o processo de elaboração do programa, a UMM reivindicou além da implantação de infraestrutura, a inclusão de equipamentos coletivos, como item pertencente a esses objetivos, pois consideravam que a moradia popular, não significa apenas provisão da habitação. Além disso, o Manual do PPM não apresentava nenhum direcionamento neste sentido. Mesmo diante desta reivindicação, este item não foi incorporado aos objetivos do programa. Desta maneira, no final do processo construtivo do Mutirão União da Juta (MUJ), os equipamentos coletivos voltaram a ser reivindicados tanto na CDHU como em outros órgãos representantes do poder público.

Este fato indica que a UMM possuía força suficiente para não abrir mão de determinadas reivindicações ${ }^{30}$. No caso do MUJ, ela conseguiu transmitir este ideário para os mutirantes, pois estes dispenderam esforços de todos os gêneros até chegar aos seus objetivos. No capítulo 3, mostramos quais dos equipamentos coletivos foram conquistados para a Vila União da Juta.

Também podemos observar, no Manual do PPM, que um dos objetivos do programa foi "implantar conjuntos habitacionais em "terrenos dotados de infraestrutura". No entanto, sabemos que na prática isso, geralmente, não se realiza. Em grande parte dos conjuntos habitacionais, a infraestrutura é um item que quando implantado acontece depois de muitos anos de

29 SÃO PAULO (Estado), 1993(a), p.2.

30 Durante o processo de elaboração do Manual do programa, foi solicitado à CDHU a alteração da expressão "beneficiário final" por "mutirantes integrantes da associação". A CDHU manteve as duas expressões no manual. No entanto, durante o desenvolvimento da União da Juta, os mutirantes recusavam-se em ser chamados de beneficiários finais, porque não acreditavam estar recebendo alguma forma de benefício do Estado, mas sim aquilo que the era de direito, conforme sentido literal da palavra, como aquilo que é legítimo, justo. 
instalação dos moradores no local, apesar de constituir-se como suporte para o bom funcionamento do bairro e da sua integração à cidade.

Desta forma, percebemos que, muitas vezes, as "boas" intenções aparecem escritas nos "Manuais", mas, nem sempre se concretizam. Além disso, grande parte das vezes, o poder público não congrega sua função social na produção de uma cidade mais igualitária. Neste caso, a palavra boas aparece entre aspas, justamente por indicar que nem sempre aquilo que se coloca como bom, de fato é bom completamente. Isso porque quando o poder público insere em um manual de um programa social a intenção de instalar conjuntos habitacionais em terrenos dotados de infraestrutura, pode-se entender que ele está participando do princípio que - mesmo será instalado em áreas onde não existe essa infraestrutura, desconsiderando-se assim, áreas potencialmente interessantes como as áreas centrais, já dotadas de infraestrutura ${ }^{31}$.

Acrescenta-se a essa questão, a seguinte situação: se nos programas habitacionais de interesse social os conjuntos habitacionais fossem, de fato, implantados nos vazios urbanos, onde a infraestrutura já estaria instalada, o poder público estaria livre dos encargos que a instalação deste item causaria e consequentemente a população alvo de tal programa social também teria os valores do financiamento reduzidos.

No entanto, o que percebemos é a permanência de processos especulativos, que desloca a população mais pobre para áreas longínquas desprovidas de infraestrutura e que favorecessem a propriedade privada da terra em detrimento do seu uso com fins sociais. No Mutirão União da Juta (MUJ), a infraestrutura foi implantada somente no final da obra, fato que

\footnotetext{
31 Conforme dados da Fundação João Pinheiros (2008), existem 6 milhões de domicílios vagos em todo país e 21.917 na região central de São Paulo, potencialmente disposto para reabilitação e utilização para fins sociais. Conforme IBGE (2010) o déficit habitacional quantitativo é cerca de 5,8 milhões de habitações para todo o Brasil. Considerando-se esses valores, percebemos que o déficit poderia ser esgotado com a utilização de imóveis vazios.
} 
dificultou todo o processo construtivo, tanto para os mutirantes que vinham de outras áreas da cidade, como para os fornecedores de materiais de construção que muitas vezes não apareciam ou atrasavam a entrega devido às dificuldades de acesso ao local.

A seleção das famílias foi realizada pela Associação de Moradores e depois habilitadas pela CDHU para participar do Mutirão União da Juta conforme exigia o regulamento do programa. De acordo com documentos da Assessoria Técnica, $60 \%$ das famílias selecionadas pela Associação União da Juta pertenciam à faixa de renda de 1 a 5 salários mínimos. Este percentual indica que, neste caso, mais da metade das famílias que participaram do mutirão pertenciam às camadas de renda mais baixa.

Ainda neste sentido, o processo de escolha das famílias do MUJ demonstrou que foi dada prioridade as camadas populares, fato que 0 diferencia de outras formas de financiamento realizadas pela CDHU, ou seja, uma das críticas refere-se ao fato da operacionalização dos programas populares realizarem-se, a partir do critério de renda e darem brecha para o questionamento quanto ao seu caráter social, que até então não era priorizado, mas que com os mutirões e, sobretudo com o MUJ ocorreu de forma diferenciada.

Não podemos deixar de apontar que a seleção das famílias beneficiárias $^{32}$ realizada pela Associação União da Juta, seguia critérios existentes no Regulamento Interno da UMM. Ainda assim, a população aceita nesta primeira seleção realizada pela Associação, teria que comprovar alguma fonte de renda que permitisse o seu comprometimento com o financiamento da casa própria.

\footnotetext{
32 No contexto de desenvolvimento da União da Juta, os mutirantes recusavam-se em ser chamados de beneficiários finais, porque não acreditavam estar recebendo alguma forma de benefício do Estado, mas sim aquilo que the era de direito, conforme sentido literal da palavra, como aquilo que é legítimo, justo. Fato que demonstra a capacidade de crítica sobre a sua realidade.
} 
Cabe ainda destacar, que a seleção das famílias à partir do critério de renda, pode significar um avanço na ampliação do caráter social, como aconteceu no MUJ. Contudo, também pode consolidar um processo de segregação socioespacial, que somado a localização periférica, gera bairros inteiros caracterizados como locais onde só moram os pobres. Esses bairros são espaços demarcados segundo a lógica de reprodução e estruturação social do espaço, ou seja, determina o lugar de cada um no espaço urbano 33 e prejudica a integração e sociabilidade entre os diferentes grupos sociais.

De acordo com dados da CDHU34, a lei 6.556 de 30 de novembro de 1989, instituiu a vinculação dos recursos orçamentários provenientes da majoração de $1 \%$ na alíquota do Imposto sobre Circulação de Mercadorias e Serviços (ICMS), para a CDHU efetuar o financiamento de programas habitacionais de interesse social|35. Este recurso foi um dos instrumentos importantes adotados para dar viabilidade ao desenvolvimento de uma política habitacional em nível estadual.

O repasse de recurso do programa era feito diretamente às associações cadastradas na CDHU, que por meio do autogerenciamento determinavam a aplicação, utilização e prestação de contas dos recursos, conforme previsto em projeto próprio. Os recursos do programa ${ }^{36}$ eram destinados ao financiamento de: materiais de construção, remuneração da mão de obra, remuneração da equipe de assessoria técnica, implantação do canteiro de obras, elaboração e aprovação de projetos, projeto e execução de infraestrutura e aquisição de terrenos.

\footnotetext{
33 Bourdieu (1997).

${ }^{34}$ SÃO PAULO (Estado), 1993(a), p.2.

35 Conforme dados da CDHU (2012), atualmente o repasse dos recursos do ICMS para os programas habitacionais representa um montante de $R \$ 800$ milhões/ano. Além disso, outra fonte importante de recursos é a carteira de mutuários que, entre de 1995 a 2007, respondeu por aproximadamente $12 \%$ do investimento habitacional.
}

${ }^{36}$ SÃO PAULO (Estado), 1993(a), p.2. 
Para cada item financiável a CDHU definiu um valor percentual como parâmetro de custos a ser seguido. Contudo, a determinação de padrão de referência de custo para os mutirões foi um processo que encontrou inúmeras dificuldades, dentre as quais podemos citar: diferenças entre as áreas e variedade das tipologias habitacionais, os sistemas construtivos, a topografia dos terrenos, as soluções das fundações, etc.

Desta forma, com vistas a dar andamento às assinaturas dos contratos a UMM adotou uma referência de custos comuns para os mutirões, tendo em vistas os padrões apresentados pela CDHU e a partir do referencial estabelecido em negociação utilizada no programa FUNAPS-Comunitário. Nesta primeira fase do Programa, relatos da coordenação da UMM apontam as potencialidades deste em relação ao "padrão CDHU":

O exemplo dessas construções é algo que começa a dar muito certo
porque consegue-se fazer uma unidade habitacional mais barata e
de melhor qualidade, esse é um argumento muito importante para
você apresentar para quem está no governo, você diz olha, se você
gasta tanto para fazer uma casa de não sei 40 ou $50 \mathrm{~m}^{2}$ e nós com
menos do que isso vamos fazer uma casa de $60 / 70 \mathrm{~m}^{2}$ o governo fica
meio sem resposta para isso. (Entrevistado E, ex-coordenador da
UMM, entrevista à autora, ago. 2010).

Assim, propunham o equacionamento desses custos considerando as particularidades de cada projeto de mutirão, o reconhecimento e tratamento das entidades conforme à necessidade de variação de limites de financiamento. No caso do Mutirão União da Juta, a associação de moradores com apoio da assessoria técnica reivindicou e conquistou o direito de execução da terraplanagem e demais itens de infraestrutura, como também estava acontecendo com os últimos mutirões implantados na região. Este procedimento ia contra a rotina definida pela CDHU e indicava mais controle por parte da Associação União da Juta, sobre a administração dos recursos em todas as etapas de construção do mutirão.

Desta forma, a liberação dos recursos pela CDHU para as Associações iniciarem as obras, acontecia através da $1^{\circ}$ Ordem de Início de Serviços (OIS) e referia-se a remuneração do projeto básico de edificação, projeto básico 
de instalação de canteiro, memorial descritivo preliminar, memorial de cálculo de Fundações e Estruturas, planilha orçamentária e projeto executivo de terraplanagem. Para tanto era necessário que todos os requisitos fossem disponibilizados pela Associação para a CDHU, a partir disso, esses requisitos passavam por um processo de aprovação pela CDHU, para que por fim fossem liberados a $2^{\circ}$ OIS para o efetivo início das obras. No entanto, os departamentos da CDHU (projetos, obras, jurídico e planejamento) eram fragmentados e por raras vezes se comunicavam, o que tornava a operacionalização do programa lenta. No mutirão União da Juta, devido a morosidade em aprovar os projetos, as obras foram iniciadas antes da liberação da $1^{\circ}$ OIS, mostrando mais uma vez que o processo de construção por mutirão era continuamente marcado por inúmeros embates e por enfrentamento as regras definidas pela CDHU que por conta da sua própria estrutura fragmentada, impedia a continuidade dos procedimentos e 0 andamento dos obras.

Os recursos destinados à construção da Vila União da Juta esgotaramse antes da finalização da obra, fato que ampliou as inúmeras dificuldades de andamento do mutirão. Dentre esses problemas, podemos citar, o advento do Plano Real e aplicação de redutor que provocou o acúmulo de perdas dos valores contratados que não mais remuneravam os serviços efetuados.

Além disso, com os anos de obras o aumento dos preços dos materiais de construção e do valor da variação da Unidade Padrão de Financiamento (UPF) ${ }^{37}$, impossibilitavam a continuidade dos mutirões com os mesmos recursos que haviam sido contratados no momento de assinatura dos convênios, ou seja, com o mesmo valor já não se construía a mesma unidade habitacional planejada e orçada inicialmente.

\footnotetext{
37 A Resolução $n^{\circ} 2130$, de 21.12.94, extinguiu a UPF. Para a atualização dos financiamentos do crédito imobiliário foi estipulado à utilização Tabela Fundação Instituto de Pesquisas Econômicas (FIPE), que correspondia ao valor da última UPF divulgada e atualizada.
} 


\subsection{Embates e conflitos}

O Programa Paulista de Mutirões foi um dos primeiros programas habitacionais que teve o mutirão com autogestão como pressuposto. Vale destacar que a inserção da temática da autogestão foi e ainda é uma das questões centrais de luta dos movimentos sociais e assessorias técnicas até os dias de hoje. Pois é justamente a sua aplicação que dá ao programa novo sentido e faz o contraponto necessário aos programas de moradia popular convencional.

Neste contexto de elaboração e implementação do programa, os movimentos populares já tinham adquirido força suficiente para questionar sua participação apenas nos momentos de planejamento com caráter consultivo, ou seja, considerando a opinião dos futuros moradores apenas para a definição projetual e durante a execução, como mão de obra. Essa noção de participação da população não contava com a atuação do futuro morador na administração e controle da construção.

No entanto, uma questão fundamental em relação à produção por mutirão é que os movimentos de moradia, juntamente com as assessorias técnicas desejavam a participação do futuro morador para além da "simples aplicação de mão-de-obra"38, ou seja, reivindicavam o controle nos processos decisórios e gerenciamento de todas as etapas da obra no mutirão.

Desta forma, devido à pressão dos movimentos sociais, a questão da autogestão assumiu papel central como item a ser incorporado pelo programa. Para a CDHU, os pressupostos que remetiam ao conceito de autogestão foram: a participação do movimento na escolha de quem seria beneficiado e o fato de contar com uma assessoria técnica própria que efetuaria projeto próprio.

38 Lopes; Rizek (2006, p. 53). 
Entretanto, o movimento social, seguindo o lema "menos mutirão e mais autogestão"39, reivindicam um novo programa que considerasse a autogestão em todo o processo, incluindo o controle dos recursos:

Todo processo político e toda conquista se dá se você tiver duas coisas, dois pontos: argumento e força. Não bastava o argumento tinha que ter a força também, e a força vinha a partir do momento em que nosso movimento conseguia valorizar algo em torno. (...) Nós tínhamos uma proposta interessante e viável, que era de que se você entregasse os recursos diretamente para a comunidade organizada a partir de autogestão nos tínhamos como fazer uma unidade habitacional de melhor qualidade e mais barata do que era feita. (Entrevistado E, ex-coordenador da UMM, entrevista à autora, ago. 2010).

É justamente neste aspecto que se encontra uma das grandes contradições da reivindicação por autogestão: o movimento "recusa a intervenção do aparelho estatal como agente implementador (de cima para baixo)" (USINA, 2012, p. 50), mas necessita dos recursos públicos para a implementação do autogerenciamento, o que torna o processo altamente conflituoso e resulta em uma autogestão semiautônoma.

Agora, essa nossa proposta tinha outro aspecto que era muito importante porque fazia com que os grandes pilares da política tradicional de habitação fossem atingindo, que era o clientelismo, que todo governo gosta de fazer a casa e depois entregar aquela casa, a pessoa sai com a sensação de que é deus no céu e ele na terra que entregou aquela casa para a pessoa, então, tem esse lado do clientelismo e tem o lado de que nós sabemos que grande parte das licitações neste país, elas tem esquemas de corrupção e aí você entrega o dinheiro para as construtoras e elas acabam financiando a campanha das pessoas. Então o mutirão com autogestão ele atingia isso, ele atacava o clientelismo, porque as pessoas faziam as suas próprias casas, fruto da sua luta, então, não eram pessoas que iam lá dizer olha é graças ao senhor (...) que nós temos a casa, mas é graças a nossa luta (...) de transformação da realidade e também nós atingíamos esse esquema de desvio de dinheiro para a corrupção, para as licitações e tal. Tudo isso com a vantagem de fazermos uma casa, uma unidade habitacional maior, melhor e mais barata do que era feito, então, ponto. (Entrevistado $E$, excoordenador da UMM, entrevista à autora, ago. 2010).

\footnotetext{
39 FELIPE, Joel Pereira. Mutirão e Autogestão no Jd. São Francisco (1989-1992): movimento de moradia,
} lugar do arquiteto. Dissertação de Mestrado, Depto de Arquitetura da EESC-USP. São Carlos, 1997. 
Dentre os elementos existentes no PPM que remetiam ao conceito de autogestão, podemos citar: indicação das associações comunitárias pela UMM, seleção das famílias e contratação de assessorias técnicas efetuadas pela associação, elaboração do projeto arquitetônico por meio das assessorias, com a participação dos futuros moradores, definição do sistema construtivo e dos materiais de construção, contratação de mão de obra e organização do mutirão.

Portanto, as inserções desses pressupostos de autogerenciamento não tinham o mesmo significado para os diferentes agentes do processo, a CDHU deseja restringir ao máximo a autogestão, enquanto o movimento queria ampliar a sua prática. Fato que iria influenciar de maneira decisiva no desenho do programa. Assim, logo que os conflitos foram aparecendo, o conceito de autogestão foi sendo adaptado de acordo com os interesses distintos presente no jogo político dos atores sociais deste processo.

É a partir dos embates e dos conflitos entre o Estado e os movimentos sociais que a noção e os limites da autogestão impostos pelo primeiro são explicitados. Há uma "miscelânea de conceitos" nos pressupostos da CDHU que jogam luz ao debate em pauta: autogestão, gestão dos recursos e organização dos trabalhos no canteiro se confundem e turvam o alcance pretendido. Na verdade, a autogestão para a CDHU é compreendida apenas como autogestão "do empreendimento" (ROYER, 2002, p. 384). Daí a pertinência de estarmos atentos para o que nós estamos entendendo como autogestão40.

Para além da avaliação da superficial da CDHU, a coordenação da UMM irá afirmar que:

A CDHU limita o exercício da autogestão, assumindo para si responsabilidades e decisões que não the caberiam. Como exemplo, podemos citar a proibição da elaboração de projetos próprios pelas assessorias técnicas dos movimentos, alegando que estes teriam uma

\footnotetext{
40 Para um debate teórico-conceitual aprofundado a respeito da autogestão consultar:
} Lopes (2007); Lopes e Rizek (2006); Lopes (2011). 
superfície acima do compreendido por eles como habitação popular, custos muito elevados e que o acervo de projetos da Companhia seria suficiente para o programa (...) A CDHU passa a influenciar diretamente as associações na escolha de assessoria técnica, projeto e processo construtivo, itens muito caros à concepção de autogestão. (RODRIGUEZ apud ROYER, 2002, p. 384385).

O fato de a CDHU desempenhar função de agente financeiro e promotor de programas sociais gera resultados contraditórios em relação aos reais objetivos do programa, ou seja, remete ao argumento de Azevedo e Andrade 41 sobre a raiz contraditória de um processo social.

Diante do exposto, podemos questionar qual seria o real papel executado pela CDHU enquanto órgão representativo da atuação do poder público. Percebemos que algumas exigências poderiam ser flexibilizadas devido às características inerentes à autogestão. A lógica do mutirão é distinta à lógica empresarial e é justamente a não consideração desta peculiaridade que, muitas vezes, "engessa" o andamento dos mutirões.

A lógica empresarial busca a eficiência mercadológica, isto é, um processo produtivo ágil, baseado na produtividade e na lucratividade como fim (a contabilidade efetuada é a seguinte: quanto mais metros quadrados construídos em uma unidade menor de tempo, mais lucros), sem que esta fórmula esteja necessariamente lastreada com a qualidade lé mais que sabido o quanto este aspecto é questionado quando se trata da construção de habitações para população de baixa renda). A estrutura altamente hierarquizada do canteiro de obras de uma empreiteira é um dos elementos que favorecem a agilidade do processo produtivo, mas a relação, de parceria e de facilitador do empreendimento, assumida pelo Estado com a iniciativa privada é, certamente, o grande diferencial quando comparado à postura deste mesmo em se tratando de programas de mutirão autogestionado.

${ }^{41}$ AZEVEDO; ANDRADE, 1982. 
Nos mutirões pautados na autogestão, os objetivos e, portanto, a lógica são outros. O processo produtivo é muito mais lento, primeiro, porque o critério não é a produtividade. Em termos gerais, a estrutura interna não é vertical, todos os operários são, ao mesmo tempo, proprietários e mutuários, portanto preocupados com a qualidade das unidades habitacionais, mas cientes da diversidade de capacidade e limite produtivo de cada um, o que exige a promoção de trocas de experiência. Até mesmo a relação com os assessores técnicos tende a ser mais horizontal e democrática dependendo do grau de autonomia e organização de cada grupo de mutirantes. Os sérios entraves que os mutirantes enfrentaram e ainda hoje enfrentam com o poder público para a liberação e controle dos recursos também impõe um ritmo mais demorado ao processo produtivo. Contraditoriamente, porque não parte da lógica mercadológica, o ritmo dos mutirões é visto como sinônimo de ineficiência, colocando em xeque a sua viabilidade.

É bastante ilustrativo o paralelo que se pode fazer, entre um canteiro de obras de uma empreiteira e um canteiro de um mutirão autogerido, estabelecido no Vídeo-Documentário "Capacetes coloridos" de Paula Constante 42 . Destacamos aqui apenas um dos aspectos tratados no documentário: a hierarquia ou horizontalidade nos canteiros a partir das cores dos capacetes. No canteiro de ampliação do campus da USP na Zona Leste, que adotou o regime de construção por empreiteitada, os capacetes de todos os agentes do processo são coloridos (para os pedreiros o capacete é laranja ou amarelo, para os ajudantes verde, eletricistas cinza e os engenheiros e arquitetos usam capacetes branco), revelando o lugar de cada operário na hierarquia da obra. Já no canteiro do mutirão autogerido da Associação Paulo Freire, ligada à União dos Movimentos de Moradia de São Paulo, os capacetes são todos brancos, expressando a horizontalidade no processo de produção.

42 Disponível em: <http://vimeo.com/13259606>. 
Não há dúvidas que o diferencial qualitativo entre as lógicas citadas, está nos objetivos de cada uma delas. Se a empreiteira tem o lucro como objetivo, o mutirão autogestionado objetiva o acesso à moradia de qualidade, mas, em última instância, também pode lograr construir um espaço coletivo de conscientização política, em decorrência do processo participativo, democrático e das permanentes lutas que são obrigados a travar com o poder público. Neste sentido, avança-se ainda na compreensão de que morar dignamente é muito mais do que a casa em si, mas requer colocar em pauta o direto à cidade em seu conjunto.

Em síntese, em que pese toda a complexidade que envolve as associações mutirantes (abordada no capítulo 3 desta dissertação) e até mesmo a consideração de supostas dificuldades provindas da adaptação operacional da CDHU aos moldes agora propostos, em geral, esta companhia limita a abrangência da autogestão e impõe, aos mutirões, normas pautadas na lógica empresarial e, numa inversão total dos princípios autogestionários, "afirma que 'as associações e assessorias têm demonstrado dificuldade de adaptação às normas CDHU'" (SÃO PAULO43 apud ROYER, 2002, p. 382-384).

A experiência do Mutirão União da Juta que trazemos neste trabalho, nos permite reiterar a perspectiva de Royer (2002) que afirma que:

\footnotetext{
"a partir do Programa Paulista de Mutirões, alguns avanços nas formas de autogerenciamento podem ser reconhecidos, tais avanços podem ser atribuídos aos constantes embates produzidos durante a sua implementação" (ROYER, 2002, p. 384).
}

Em outras palavras, sem a pressão dos movimentos sociais a autogestão não teria avançado.

${ }^{43}$ SÃO PAULO (Estado). Companhia de Desenvolvimento Habitacional e Urbano (1995). 


\subsection{Panorama e abrangência do programa}

Não realizamos uma avaliação de todos dos programas habitacionais que existem atualmente na CDHU, porque este procedimento foge do escopo da pesquisa. Contudo, apresentamos uma síntese sobre o número de unidades habitacionais entregues no Estado de São Paulo, desde a CECAP até as obras iniciadas no governo de Geraldo Alckmin ${ }^{44}$. Na Tabela 1 e no Gráfico 1 é notável o aumento do total de unidades habitacionais entregues desde o período de atuação da CECAP até a CDHU, que variou de quase 18 mil para cerca de 500 mil.

Tabela 1| Unidades Habitacionais Entregues no Estado de São Paulo (Jun/1966-Dez/2014)

\begin{tabular}{l|l|c|c}
\hline Denominação & Período de Atuação & Total & $\%$ \\
\hline CECAP & Jun/1966 - Jan/1981 & 17.712 & 3.18 \\
\hline CODESPAULO & Jan/1981 - Mar/1984 & 21.906 & 3.94 \\
\hline CDH & Mar/1984 - Jun/1989 & 14.531 & 2.61 \\
\hline CDHU & Jun/1989 - Dez/2014 & 501.663 & 90.25 \\
\hline Total & 555.812 & 99.98 \\
\hline
\end{tabular}

Fonte: CDHU-GGI Gerência de Gestão da Informação e DPFDiretoria de Planejamento e Fomento.

Org: Fabrícia Mitiko Ikuta

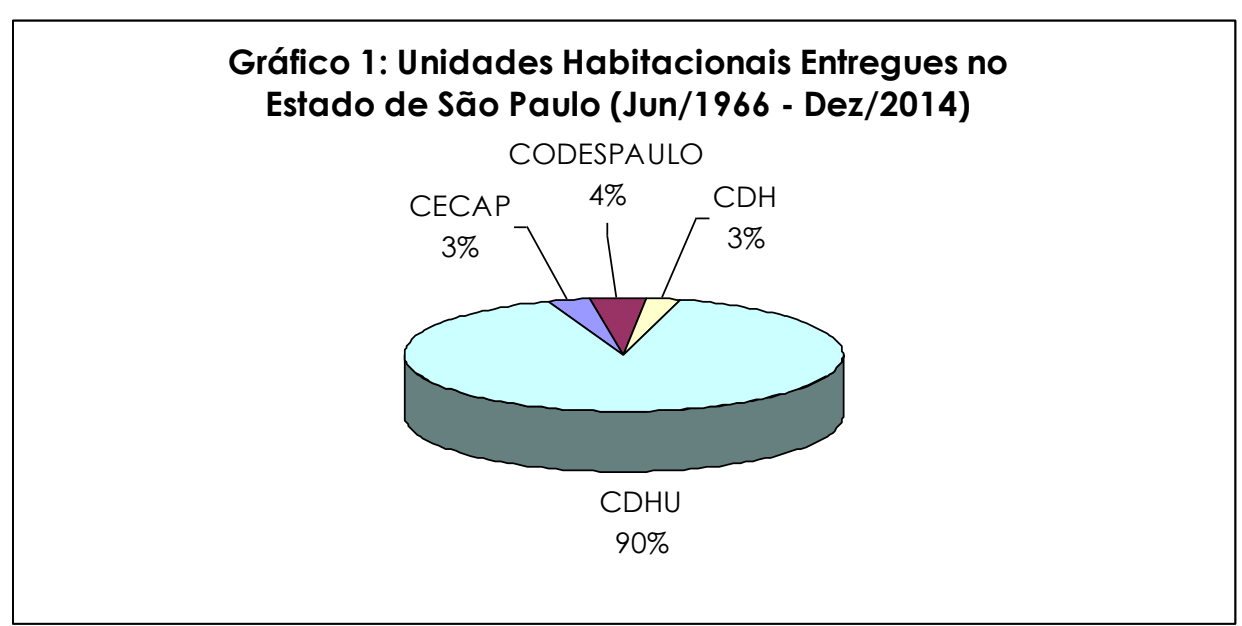

Fonte: CDHU-GGI Gerência de Gestão da Informação - DPF-Diretoria de Planejamento e Fomento. Org: Fabrícia Mitiko Ikuta.

${ }^{44}$ Com início em 01/01/2011 e previsão de entrega em 31/01/2014. 
No Gráfico 1 evidenciamos a participação da CDHU com 90\% do número total de unidades habitacionais entregues, em detrimento da participação bem menor (até 4\%) das outras companhias que atuaram na execução e/ou financiamento de programas habitacionais no Estado de São Paulo. Esse destaque da CDHU se deve, em parte, aos 24 anos de atuação, superior ao que se registrou no caso das demais companhias: CECAP, 15 anos; CODESPAULO, 3 anos; e CDH, 6 anos. Entretanto, também acreditamos que se deve à necessidade de enfrentar, em grande escala, o desafio de suprir as necessidades habitacionais paulistas, sobretudo nas três últimas décadas.

Por fim, vale ressaltar que no contexto atual, a produção por mutirão autogerido, realizada pela CDHU, apresenta um número muito reduzido. Tanto na Tabela 2, quanto no Gráfico 2 podemos observar o número de unidades habitacionais em andamento, com recursos da CDHU, em abril de 2013. Chama a atenção o fato de que há grande discrepância entre as diversas modalidades de produção de unidades habitacionais.

Tabela 2|Unidades Habitacionais Produzidas pela CDHU, em Andamento, por Modalidade, Abril/2013

\begin{tabular}{l|r|c}
\hline \multicolumn{1}{c|}{ Modalidade } & Total & $\%$ \\
\hline Empreitada & 9.205 & 27 \\
\hline Auto-Construção & 5.158 & 15 \\
\hline Administração Direta & 16.083 & 48 \\
\hline Administração Direta Por Empreitada & 2.452 & 7 \\
\hline Mutirão & 972 & 3 \\
\hline Total & 33.870 & 100 \\
\hline
\end{tabular}

Fonte: CDHU - GGI Gerência de Gestão da Informação - Diretoria de Planejamento e Fomento.

Org: Fabrícia Mitiko Ikuta. 


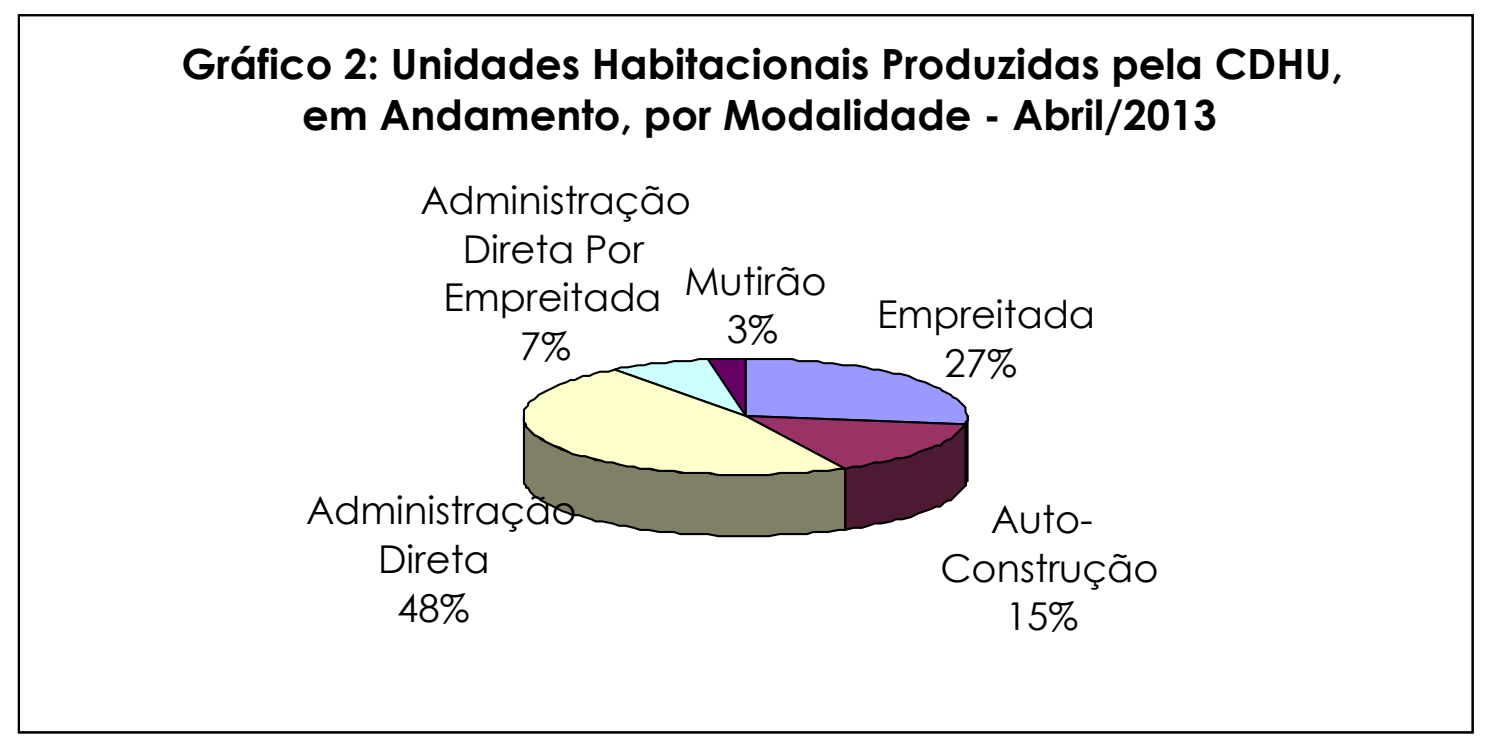

Fonte: CDHU - GGI Gerência de Gestão da Informação - Diretoria de Planejamento e Fomento.

Org: Fabrícia Mitiko Ikuta.

No total são 33.870 unidades habitacionais em andamento, entre as quais se destaca a modalidade de produção administração direta, com $48 \%$ do total. Esta modalidade visa atender a população de baixa renda, por meio de parcerias entre a CDHU e pequenos e médios municípios. Os recursos financeiros da Companhia são repassados às Prefeituras e serão administrados pelos Municípios para a execução/construção das unidades habitacionais e implantação da infraestrutura e melhorias urbanísticas.

Por outro lado, no Gráfico 2 ressalta-se que a modalidade mutirão apresenta a menor porcentagem (3\%) do total de obras em andamento, com recursos da CDHU. Esta modalidade tem por objetivo atender as demandas de associações ou cooperativas para habitação de interesse social, prioritariamente às famílias com rendas mais baixas. No entanto, o que percebemos é que justamente na faixa de renda onde se concentra a maior demanda temos o menos percentual, o que nos permite questionar 0 caráter social dos programas da CDHU. 
As demais modalidades de produção visam atender outras demandas, por exemplo: a empreitada é para atendimento de municípios de médio porte e/ou inseridos em regiões metropolitanas; enquanto a autoconstrução oferece à população de baixa renda a possibilidade de construir a casa própria, via parceria da CDHU com os municípios por meio de programas específicos.

Atualmente, a CDHU desenvolve, entre outros programas, o programa de PARCERIA COM ASSOCIAÇÕES E COOPERATIVAS, cujos objetivos constam na Lei Estadual n. 9.142/ 95, atualizada pela Lei 10819/01 (abordado no capítulo 3). Neste programa podemos identificar a inserção de parceria com cooperativas habitacionais, fato que não era contemplado pelas leis do país.

Conforme Relatório da CDHU45, este programa atende a modalidade de Mutirão Associativo e Gestão Compartilhada. O primeiro possui a mesma operacionalização do Programa Paulista de Mutirões (PPM), ou seja, a CDHU disponibiliza o terreno, fornece e aprova o projeto e repassa os recursos para as associações. Estas, por sua vez, possuem como função administrar a obra, selecionar as famílias e contratar assessoria técnica e mão-de-obra especializada. Portanto, podemos observar que, de certa forma, este programa representa uma continuidade do PPM.

No entanto, percebe-se que alguns fatores fundamentais foram aos poucos sendo alterados, como exemplo, podemos citar, o fato de a CDHU fornecer o projeto arquitetônico. Este aspecto é visto, pelas lideranças dos movimentos sociais, como fator que deu maior agilidade ao processo de aprovação dos projetos e permitiu, certa redução da burocracia que enrijecia o andamento do mutirão. Podemos perceber que os conjuntos

45 SECRETARIA DE ESTADO DA HABITAÇÃO. COMPANHIA DE DESENVOLVIMENTO HABITACIONAL E URBANO. Demonstrações contábeis relativas ao exercício findo em 31 de dezembro de 2010: Relatório da Diretoria. São Paulo: CDHU, 2011. 
habitacionais produzidos desta forma perdem muito em qualidade arquitetônica e urbanística.

Também podemos observar no Relatório da CDHU46, que o termo autogestão nem se quer é citado e passa a ser desenvolvido a modalidade de Gestão Compartilhada. Nesta modalidade, todo o processo de produção do conjunto habitacional resulta de incorporação imobiliária, ou seja, cabe a CDHU, aprovar o projeto e licitar as obras de terraplenagem, infra-estrutura, edificações (fundação, estrutura, vedação, cobertura e instalações $\left.{ }^{47}\right)$. Restando aos mutirantes as obras de acabamento do conjunto habitacional e às entidades o acompanhamento das obras e os trabalhos sociais.

A despeito desta consideração, é interessante observar como a participação das Entidades Organizadoras e dos Mutirantes ficou reduzida a sua utilização como mão de obra não remunerada, perdendo todo poder de decisão e de autocontrole do processo construtivo. Este fato nos deixa o alerta de que é preciso duvidar de processos onde prevalece a ausência de conflitos e de permanência dos consensos.

Vale destacar que a expressão "incorporação imobiliária" é comumente utilizada nas transações referentes ao mercado imobiliário, comprovando a tendência, cada vez mais expressiva, de adicionar elementos mercadológicos à produção de habitação social.

Harvey (1996, p. 49) afirma que processos como esse disseminaram-se globalmente e passaram a ocupar o "centro do palco na formulação da política urbana". Para o autor, nas décadas de 1970 e 1980, existia uma abordagem ligada ao gerenciamento, que deu lugar a "formas de ação de empresariamento", principalmente, nos países capitalistas avançados. Esse

\footnotetext{
$46 \mathrm{lbid}$, p. 67.

${ }^{47}$ Ibid, p. 67.
} 
empresariamento possui como característica a noção de "Parceria PúblicoPrivadas" (PPPs), onde os poderes públicos locais buscam atrair fontes de financiamento privada. Nas palavras do autor:

"em muitos casos isso significou que o setor público assumisse o risco e a iniciativa privada ficasse com os benefícios, embora existam exemplos suficientes em que isso não se aplica, de forma que qualquer generalização absoluta se torna perigosa". (HARVEY, 1996, p. 53)

No entanto, o autor afirma ainda que as PPPs, podem resultar em uma "coalização de interesses formada basicamente por incorporadores imobiliários e financistas locais"48, fato que seria regido pela lógica mercadológica e especulativa. Assim, quando esta lógica é aplicada em empreendimentos pontuais (como de habitação popular) pode significar muito mais o desenvolvimento econômico do que a melhoria das condições habitacionais para as populações mais empobrecidas. Consequentemente, políticas como essas, poderiam obter custos sociais desastrosos ${ }^{49}$.

\footnotetext{
48 Harvey (1996, p. 53).

${ }_{49}$ Cabe salientar, que em meio a processos onde opera uma lógica perversa de produção habitacional, ainda permanecem algumas assessorias técnicas que possuem um trabalho comprometido com as questões sociais. Dentre essas assessorias, podemos citar a USINA, entidade que acompanhou todo o processo de desenvolvimento do Mutirão União da Juta (abordado no capítulo 3).
} 


\section{CAPÍTULO 3 O MUTIRÃO UNIÃO DA JUTA}

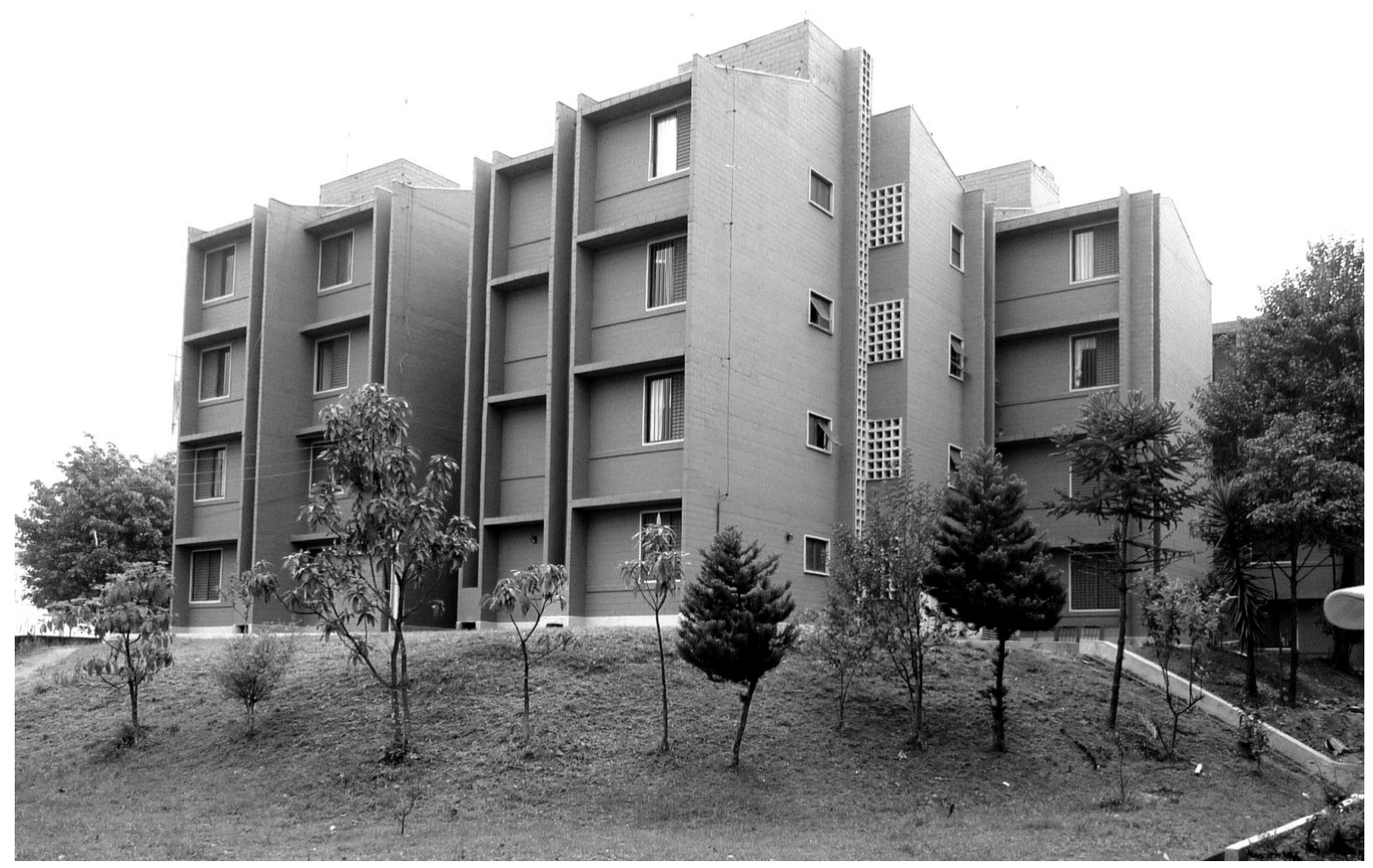

Fonte: Fabrícia Mitiko Ikuta. 


\section{CAPÍTULO 3 | O MUTIRÃO UNIÃO DA JUTA}

Nos capítulos anteriores apresentamos como se deu 0 desenvolvimento institucional da CDHU e efetuamos uma releitura das realizações da promoção pública de habitação popular através de programas alternativos de construção por mutirão no estado de São Paulo. Destacamos em particular um dos programas de mutirões de promoção pública de habitações populares em São Paulo "Programa Paulista de Mutirão" (PPM), modalidade na qual se enquadra o Mutirão União da Juta (MUJ).

Neste capítulo, partimos para a investigação dos reflexos práticos destas ações no ambiente construído. Entendemos que os resultados deste programa não são uniformes e por isso apenas uma análise com base empírica poderia oferecer elementos substantivos para a compreensão da temática. Dessa forma, faremos um resgate histórico do MUJ elencando os componentes que envolvem todo o processo de produção de moradia popular, não apenas em suas dimensões técnicas, construtivas e formais, mas, sobretudo nas formas de articulação, de organização e de mobilização coletiva baseada na autogestão.

Partimos do princípio de que a forma de produção do MUJ, não se assemelha a produções tradicionais, mercadológicas, onde impera a lógica do lucro. O MUJ aparece como contraponto a este modelo tradicional de conceituar, projetar e construir as Habitações de Interesse Social (HIS). A questão que queremos destacar sobre o MUJ é a ideia de que um espaço criado como solução imediata para uma demanda habitacional real pode se tornar uma oportunidade de experimentar novas formas de produção de moradia popular. O MUJ deixa o testemunho de que em uma realidade complexa, onde diferentes atores e diferentes abordagens se entrelaçam, podemos obter resultados interessantes em termos de processo de produção autogestionário e de projeto de arquitetura e urbanismo. 


\subsection{Como nasceu o mutirão: o processo de associação}

Narrar o exato momento de nascimento de um processo de luta por moradia, por meio de movimentos populares não é uma tarefa fácil. Primeiro, porque nem sempre existem documentos que narram esse episódio inicial. Segundo, porque muitas vezes em meio a uma conjuntura de inúmeros acontecimentos turbulentos ${ }^{50}$ não se sabe ao certo qual foi o ponto de partida que produziu o resultado específico. E terceiro porque em geral, são vários aspectos que em conjunto produzem alguma reação, ou seja, a heterogeneidade de organizações com distintas trajetórias, as formas de luta diferentes, os mais variados projetos políticos, compõem uma trama complexa que pode produzir um conjunto de resultados inesperados.

O processo de formação do Mutirão União da Juta não foi diferente. Ele está fortemente associado a uma conjuntura histórica muito rara de confluência entre as Comunidades Eclesiais de Base (CEBs), ligadas a Igreja Católica, o sindicato dos trabalhadores (que haviam formado o Partido dos Trabalhadores), as universidades (via Laboratórios de Habitação dos cursos de arquitetura e urbanismo) e os novos movimentos sociais ${ }^{51}$ de luta pela moradia dos anos de 1980.

Segundo depoimento de um dos moradores, a origem do processo de associação aconteceu da seguinte maneira:

Na zona leste começou bastante assim, a partir das Igrejas. Então, pessoas da comunidade que se interessavam chamavam, noticiavam nas missas e quem tivesse problema de moradia

\footnotetext{
${ }^{50}$ Por exemplo, as diversas ocupações da Fazenda da Juta e os conflitos resultantes, que serão abordados adiante.

${ }^{51}$ Conforme Gohn (2010) apud Touraine (2005): "Um movimento social é a combinação de um conflito com um adversário organizado e da referência comum dos dois adversários a um mecanismo cultural sem o qual os adversários não se enfrentariam, pois poderiam se situar em campo de batalha ou em domínio de discussão completamente separados" (TOURAINE 2005, p.18-19).
} 
poderia comparecer para tratar desse problema. Aí as pessoas começaram a se reunir e tentar encontrar uma solução para o problema da habitação (...) (Entrevistado B, Associação de moradores MUJ, entrevista à autora, ago. 2010).

No MUJ o apoio dado pela Igreja esteve fortemente ligado à figura do bispo Dom Luciano, como um dos atores responsáveis por uma forte articulação política com os governos municipais e estaduais, principalmente no desenrolar da negociação do terreno para a construção das moradias. Segundo depoimento de um dos moradores:

Ela (Igreja) apoiava politicamente e dava estrutura jurídica também, quando alguém era preso ou qualquer tipo de transgressão da lei tinha os advogados ligados à Pastoral da Moradia que ajudava. Então a gente conheceu o movimento através da Igreja (Entrevistada A, MUJ, entrevista à autora, ago. 2010).

O mês de fevereiro de 1988 marcou o início de um longo processo de negociação entre movimento social e poder público que depois de muitos embates, resultou na conquista de uma gleba na Fazenda da Juta. Neste período, grandes grupos de famílias organizadas pelo Movimento dos Trabalhadores Sem Terra Leste 152 e União dos Movimentos de Moradia de São Paulo (UMM), permaneceram 50 dias em uma área no Jardim Colorado, na Zona Leste da cidade, pertencente ao Governo do Estado de São Paulo. Na ocasião o então governador, Orestes Quércia, comprometeu-se a destinar 450 lotes urbanizados em terreno na Fazenda da Juta53, para as famílias que participaram da ocupação (ver Figura 6).

No ano seguinte, em 1989 aconteceu a assinatura do primeiro convênio, entre a CDHU, órgão governamental representante do Governo de São Paulo (Quércia 1987 - 1991) e a UMM, para construção de

\footnotetext{
52 Movimento dos Trabalhadores Sem Terra Leste I foi criado em 1987 e apoia outros movimentos de luta por moradia.

53 De acordo com Arantes (2002), a Fazenda da Juta era uma enorme gleba que estava abandonada há muitos anos e que havia sido desapropriada pelo Governo do Estado para fins de interesse social; naquele momento ela estava servindo como depósito de lixo doméstico e industrial.
} 
moradias em regime de mutirão. No entanto, este documento representou apenas o primeiro passo de um longo percurso histórico marcado por intensos embates políticos que envolvem a luta pela moradia no Brasil.

Para que possamos entender o início de todo o processo, cabe ter em conta que, oficialmente, a Associação União da Juta foi fundada em 1992, mas as lutas já vinham de muitos anos atrás, desde o momento de filiação à UMM (regional Leste I). A sua formação inicial contava com a participação de famílias oriundas da zona leste da capital do Estado de São Paulo que formavam a base do movimento, chamada Grupo de Origem 54 . A partir desse Grupo de Origem as famílias deveriam cumprir uma rotina de participação no movimento baseada em diversas formas de expressão, como: manifestações, passeatas, reuniões, assembleias e ocupações que resultavam em uma pontuação proporcional a importância das diferentes atividades do movimento. Quanto maior a pontuação, maior a possibilidade de seleção para o próximo mutirão conquistado junto aos órgãos públicos 55 .

\footnotetext{
${ }^{54}$ Conforme relatado pela secretaria da UMM, o movimento trabalhava com Grupos de Origem que, dependendo da região de formação, eram compostos por número muito elevado de famílias, podendo ultrapassar mais de cem pessoas, como aconteceu na época do Mutirão União da Juta. Atualmente, para formar um Grupo de Origem é necessário a participação de no mínimo cinco famílias, não devendo ultrapassar 100 família. Este aspecto auxilia-nos a perceber o período de efervescência política pelo qual passava o país e atualmente o seu encolhimento numérico que também pode significar um encolhimento político.

${ }^{55}$ Segundo o Regulamento Interno do Movimento dos Trabalhadores Sem-Terra Leste 1 (2010), os grupos de origem são a base do movimento, "a porta de entrada para a luta, onde começam a descobrir como conquistar a terra e a transformar nossa necessidade individual em demanda coletiva e política". Em entrevistas com os moradores da Juta, foram apontadas as dificuldades que as famílias encontravam para cumprir as regras estabelecidas, por conta de inúmeros contratempos. As pontuações eram maiores conforme a importância da forma de mobilização, ou seja, não bastava estar presente apenas nas reuniões da Associação e do Movimento, era preciso participar das passeatas e ocupações, pois juntas elas somavam uma pontuação maior. Este fato fazia com que as famílias compostas por um número menor de integrantes ou que não podiam participar de todas as formas de manifestações permanecessem por muitos anos no grupo de origem.
} 


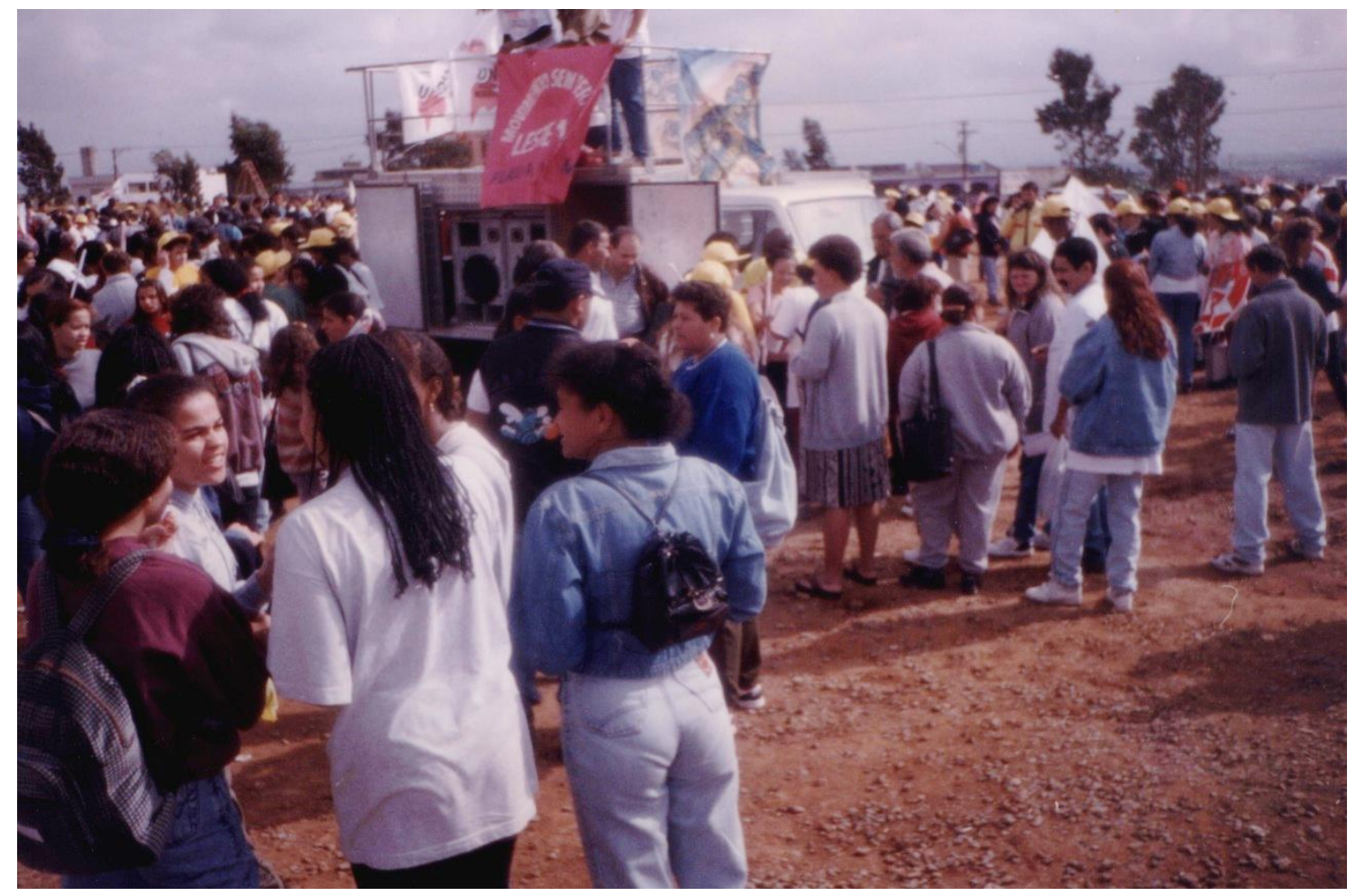

Figura 6| Primeiras ocupações na Fazenda da Juta Fonte | acervo pessoal morador.

A associação de moradores possuía a importante função de definição da demanda habitacional (a partir das regras estabelecidas no PPM como faixa de renda e capacidade de endividamento e também conforme o Regulamento Interno do Movimento) e, entre outras tarefas, o papel de administrar e gerenciar os recursos públicos e todas as etapas da obra. Segundo as normas do PPM, a Associação enquanto pessoa jurídica é responsável por contratar a Assessoria Técnica para a elaboração e execução do projeto. No entanto, neste momento já tinham acontecidos os primeiros contatos da Associação com a equipe de Assessoria Técnica. Neste período a USINA, já havia trabalhado como assessora técnica junto a outras associações 56 , o que facilitou o conhecimento da forma e do tipo de trabalho que seria executado. Deste modo, percebemos que a Assessoria técnica esteve presente desde a origem da Associação.

56 Associação Terra é Nossa em Osasco/SP (1989), com a Associação de Construção Comunitária de Diadema/SP (1990), com a Associação de Construção 26 de Julho em São Paulo/SP (1991) e com a Associação por Moradia de Osasco, Copromo em Osasco/SP (1992). 
As primeiras reuniões da Associação União da Juta aconteceram em um pátio de uma escola da região, que emprestava o espaço quinzenalmente. Essas reuniões eram importantes momentos de esclarecimentos de dúvidas, de exposição das formas de lutas, de discussão e debate projetual, que davam coesão ao mutirão e aproximavam a Associação, a Assessoria Técnica e as famílias que iriam participar do mutirão.

Passaram-se dois anos desde que as primeiras ocupações aconteceram e nenhuma providência foi tomada por parte do poder público. Então, cerca de cinco mil famílias que tinham como objetivo pressionar o governo do estado a dar andamento ao processo de negociação da gleba da Fazenda da Juta realizou uma Manifestação na Avenida Paulista, uma das principais avenidas da cidade de São Paulo, onde na época localizava-se o prédio da CDHU. Contudo, não obtiveram o resultado esperado.

Diante deste quadro, durante a madrugada do dia 26 de julho de 1990, aproximadamente duas mil famílias se organizaram em 30 grupos de luta por moradia da região Leste I e realizaram a $2^{\circ}$ ocupação, desta vez, do próprio terreno da Fazendo da Juta. Nesta área futuramente seriam construídos os mutirões das seguintes Associações: União da Juta, Juta 26 de Julho, Nova Esperança e Nova Belém ${ }^{57}$.

Estes momentos de ocupação são caracterizados pelos manifestantes como momentos de ampliação do campo de tensões. Segundo documentos da USINA, nesta ocasião foram mobilizados caminhões da tropa de choque, helicópteros, dezenas de viaturas e aproximadamente 200 policiais fortemente armados. Diante desta situação de extrema tensão, os manifestantes decidiram por improviso

\footnotetext{
${ }^{57} \mathrm{O}$ mutirão Juta 26 de Julho foi financiado pelo governo municipal durante a gestão da prefeita Luiza Erundina (1989-1993), por meio do programa FUNAPS-Comunitário. O mutirão União da Juta foi um dos precursores em convênio com o Governo Estadual.
} 
darem as mãos uns aos outros formando um círculo de proteção, colocando as crianças ao centro deste círculo para impedir que a polícia efetuasse a desocupação da área. O depoimento de um dos sujeitos que participou desta ocupação descreve de forma singular a importância deste momento para o fortalecimento do movimento:

"O que mais marcou a ocupação da Juta foi o circulo que foi
formado. Foi já durante o dia seguinte, a hora que a policia... de
repente surgiu a ideia. Pra não deixar a policia entrar e
desmanchar os barracões, a ideia era cercar. Cada grupo cercar
o seu barracão. Mas de repente, foi uma coisa que não foi
programada, de repente formou-se um circulo grandão (ao redor
do terreno). Foi uma coisa impressionante mesmo. Todo mundo se
deu as mãos. O helicóptero voando na Avenida Sapopemba, o
policiamento ali na frente, parado. Aquele monte de cachorros
aquela (...) pressão... A gente ficou muito tempo lá de mãos
dadas... umas 2 horas, enquanto acontecia as negociações.
Depois veio a notícia que o (governador) Quércia tinha liberado a
área e podia desmobilizar... Pro povo (pra nós), o gosto da
conquista, né... pro povo sentir que pode fazer". (Mutirão e
Autogestão - Jornal dos Mutirões Autogestionário, 1992)

Essa resistência das famílias em permanecer na Juta fez com que o governador atendesse as suas reivindicações, com lançamento de edital de terraplanagem da Juta, 561 lotes urbanizados para construção de casas em regime de mutirão autogerido. Esse acontecimento marca o início de um processo de abertura para negociação e uma das primeiras conquistas dos movimentos perante o governo estadual.

Ao mesmo tempo, outras formas de organização dos movimentos sociais de luta por moradia aconteceram e deram corpo e força para diversos segmentos de atuação dos movimentos. Podemos citar, como exemplo, o $1^{\circ}$ Encontro dos Mutirões em São Paulo, que aconteceu em 13 de dezembro de 1992 e reuniu movimentos sociais, associações de moradores, assessorias técnicas e população para debater questões centrais, como: o trabalho não pago nos mutirões, a autogestão e o papel das assessorias técnicas. Também foram abordadas questões operacionais relacionadas às instâncias de deliberação, prestação de 
contas, medições dos trabalhos executados e forma de liberação das parcelas do financiamento.

Neste primeiro Encontro foi sugerida a criação de um Fórum de Mutirões e de uma comissão composta por um representante de cada mutirão, com a função de encaminhar as propostas apresentadas neste e nos Encontros futuros. Foi um momento importante de construção coletiva de espaços de debates e busca de soluções para os problemas encontrados na produção por mutirão. Também auxiliaram na tomada de consciência sobre a problemática da moradia e possibilidades de superação desta, por meio da luta coletiva.

A UMM, juntamente com a USINA, organizou uma visita de um grupo de aproximadamente 93 mutirantes 58 às Cooperativas de Vivenda por Ajuda Mútua no Uruguai (ver Figura 7). Na época o movimento uruguaio era um modelo de cooperativismo para a habitação social ${ }^{59}$, por isso influenciou diretamente no sentimento de confiança e força para a luta por moradia. Segundo Arantes (2011), este procedimento compõe a dialética da negação e positivação nas práxis dos movimentos sociais, ou seja, primeiro nega-se a ordem existente las ocupações e demais manifestações públicas do conflito vivido expressam essa negação), para posteriormente pensar em uma nova ordem social60. Podemos perceber nas falas dos entrevistados a reação de positivação diante das Cooperativas Uruguaias:

Era muito bonito, um lugar muito bem planejado, cheio de plantas. Lá não existia muros nem cercas, como aqui, era só uma "muretinha", uma plantinha que separava a casa. E ninguém

58 Mutirantes é a designação usualmente utilizada para os futuros moradores que trabalham nos mutirões de construção de habitação popular.

59 Conforme Baravelli (2006), a FUCVAM - Federación Uruguaya de Cooperativas de Vivienda por Ayuda Mutua, nasceu no Uruguai, no final da década de 60 e neste período, já possuía um marco legal e de crédito instituído para a habitação popular.

60 Informação recebida por Arantes no Seminário Práticas de Morar, em 2011. 
modificava a obra. Então, nós pensamos assim: nós também podemos fazer alguma coisa do tipo. (Entrevistada A, MUJ, entrevista à autora, ago. 2010).

Além das Cooperativas, também foram realizadas visitas a outros mutirões, por exemplo, o COPROMO em Osasco e o Talarabl na zona sul de São Paulo, importantes obras que representavam conquistas dos movimentos sociais, aproximavam os mutirantes destas realidades e auxiliavam na preparação conjunta para a obra.

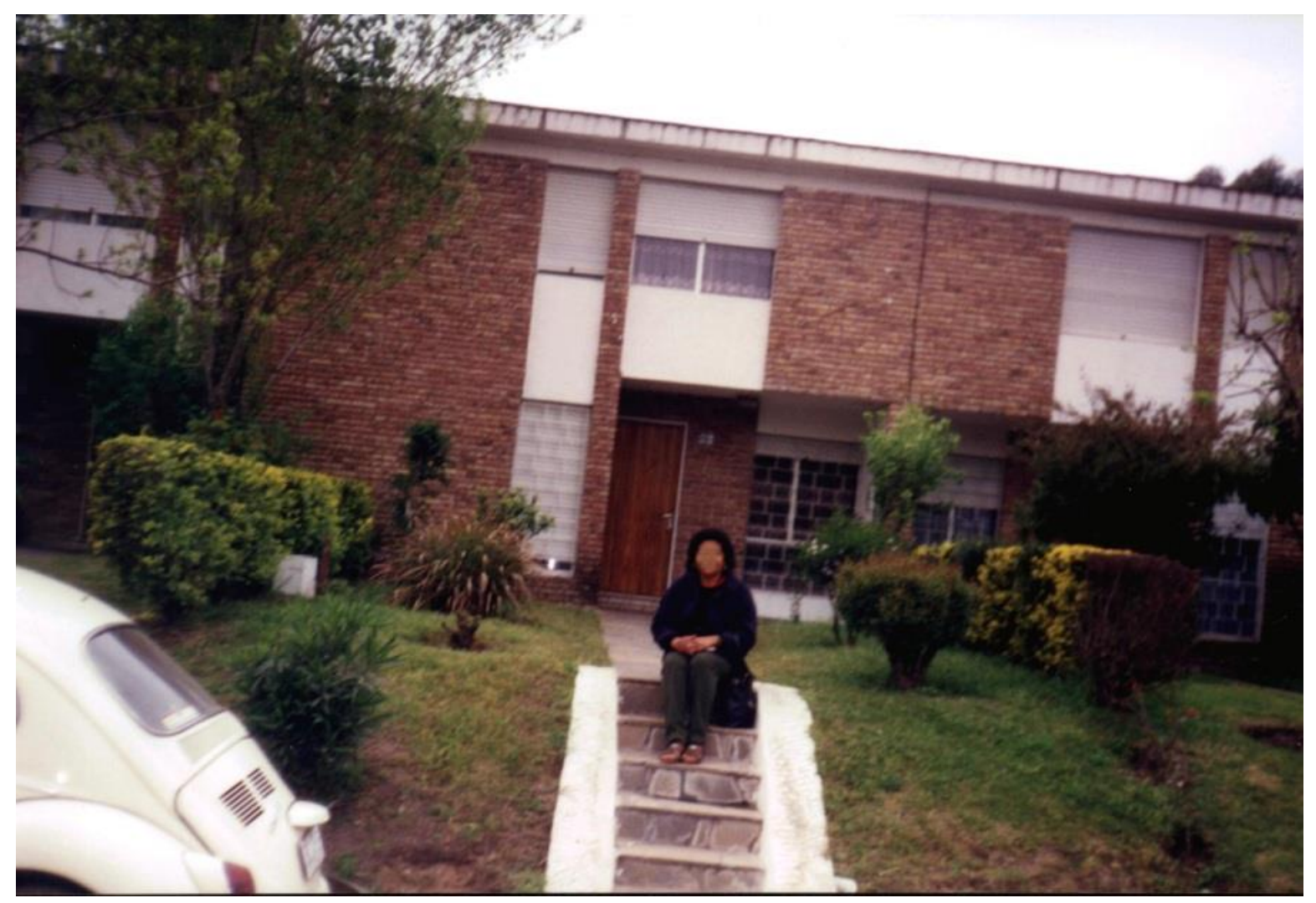

Figura 7| Visita dos moradores às Cooperativas Uruguaias.

Fonte | acervo pessoal de morador.

Em 24 de junho de 1992 foi assinado contrato de construção por mutirão com autogestão, entre a CDHU e a Associação de Moradores da União da Juta. Este fato possui caráter ambíguo, pois no primeiro

61 De acordo com a USINA: "TALARA: Associações Pró-Moradia Zona Sul; dos Moradores do Jardim Comercial e Adjacências; Pró Moradia do Jardim das Palmas e Pró-Moradia Parque Fernanda - Guarapiranga, São Paulo. O conjunto Talara (nome de uma das ruas que dá acesso a área) conta hoje com 20 prédios de 5 e 6 andares, salão comunitário, sede das associações e uma creche". Disponível em: www.usinactah.org.br. Acesso em: 07 nov. 2012. 
momento indicou um avanço na luta por moradia. Todavia, também significou o início de um processo de negociação política que envolveu a construção de moradia popular por meio do Mutirão União da Juta. É sobre este processo que trataremos a seguir.

\subsection{A relação entre o estado e a UMM: o processo de negociação}

A conquista da terra e a assinatura dos contratos representaram uma ascensão da questão da moradia, sobretudo a partir do governo Luíza Erundina na prefeitura municipal (1989 -1993) e dos programas de mutirões autogeridos desenvolvidos na sua gestão62.

Com efeito, o governo estadual (José Fleury, 1991-1995) se via obrigado a dar uma resposta às reivindicações dos movimentos sociais e abrir espaço para as negociações já que, com o final da gestão Erundina, as pressões tinham sido canalizadas para o governo do Estado. No entanto, o governo do estado possuía orientação favorável ao mutirão, mas contrário à autogestão, um princípio essencial para a Associação de Moradores União da Juta. Este tornava o processo de negociação do MUJ ainda mais problemático.

Passados quase um ano após a assinatura do contrato, diante de nenhuma resposta por parte dos órgãos públicos, as famílias decidiram "entrar no terreno" e iniciar as obras, sem autorização da CDHU. Este acontecimento é descrito por um morador como característico da força e da luta da Associação União da Juta:

Nós brigamos, ocupamos, fomos para a porta do governo várias vezes e não saía a Ordem de Início para nós podermos começar a obra. (...) No dia 5 de junho de 1991 ou 1992, nós entramos e ocupamos a terra. Quando nós entramos já ligaram para a CDHU e falaram que tinham ocupado a área aqui da Juta e quando eles souberam que era os próprios mutirantes que iriam construir, eles recuaram e convidaram a gente para negociar e logo se comprometeram a liberar o dinheiro para começar as obras.

\footnotetext{
${ }^{62}$ Para mais detalhes sobre o assunto ver BONDUKI (1992) é o Nabil né? .
} 
Então, tudo que nós fizemos aqui foi obrigado. Porque eles não tinham vontade política de construir casa para pobre. (Entrevista C, MUJ, entrevista à autora, ago. 2011).

Desta forma, em 01 de julho de 1993, depois de muitas reuniões, manifestações e ocupações foi dada a Ordem de Início de Serviços (OIS) para o MUJ, que já havia iniciado a obra. No entanto, antes de procedermos à análise do mutirão, propriamente dito, ou seja, da construção coletiva no canteiro de obras, consideramos importante entender como aconteceu à elaboração do projeto de arquitetura.

\subsection{Questionamento de paradigmas ou submissão às regras estabelecidas: a elaboração do projeto arquitetônico}

O processo de negociação da Associação União da Juta com o poder público, abordado anteriormente (item 3.2), contava com o apoio técnico da USINA. Desde o início a assessoria buscou estabelecer um espaço de diálogo aberto entre os participantes do mutirão.

Durante as primeiras reuniões, a assessoria realizou um resgate de memória da população, visando conhecer as origens dos participantes onde nasceram e viviam -, as expectativas dentro do mutirão e o potencial de trabalho de cada um. Neste momento inicial, também procuraram definir os objetivos em comum e os papéis de cada um dentro de um processo de produção baseado no trabalho coletivo, no apoio político e organizativo.

A USINA possui uma metodologia de trabalho baseada na participação dos futuros moradores em todas as etapas da obra. Da mesma forma, também procuravam debater com os moradores a adequação do programa de necessidades $e$ as características construtivas e tecnológicas.

A proposta inicial de construir edificações em quatro pavimentos assustou e gerou uma reação de negação entre os mutirantes, a maioria 
deles desejava obter uma casa unifamiliar isolada no lote. Uma vez instaurado o processo de discussão projetual, a equipe técnica apresentou um elemento que por si só justificaria sua escolha: a construção em edificações multifamiliares, proporciona a ampliação do número de unidades habitacionais e, consequentemente, do número de famílias contempladas para aquele mutirão. Em meio a um período de grande necessidade habitacional, decidiram sobrepor o interesse coletivo ao interesse particular, ou seja, trocar a tipologia unifamiliar pela multifamiliar.

Um ponto de destaque do MUJ foi a forma de definição do Regulamento de Obras (Anexo 1), que foi negociado com o movimento, contrapondo o paradigma tradicional de construção de casas populares, em que tal regulamento é imposto hierarquicamente. A Associação União da Juta, a assessoria técnica e os futuros moradores, definiram, coletivamente, como deveriam ser cumpridas as atividades no canteiro de obras, isto é, estabeleceram como seriam compostas as equipes de trabalho, as eleições das lideranças e dos coordenadores das equipes, a reposição de faltas em dias de trabalho, a periodicidade das assembleias, enfim, tudo aquilo que envolvia o cotidiano da obra. Desta maneira, garantiram maior motivação do trabalho no canteiro e envolvimento de todos os interessados nas diversas fases do processo, rompendo o modelo convencional da construção civil de habitação.

Para a apresentação do projeto de arquitetura foi marcada assembleia geral com todas as famílias. A assessoria trouxe o projeto impresso em grandes pranchas de folhas de papel AO (tamanho 1,0m $\mathrm{x}$ $0,60 \mathrm{~m}$ ) para que todos pudessem ver e opinar sobre o projeto. Nas pranchas havia a primeira proposta em planta das tipologias habitacionais. A assessoria teve o cuidado de humanizar a planta do apartamento para facilitar o entendimento dos desenhos e demonstrar que haviam diferentes possibilidades de layout, ou seja, os moradores 
poderiam escolher entre distintas formas de disposição do mobiliário dentro do apartamento (ver, Figura 8).

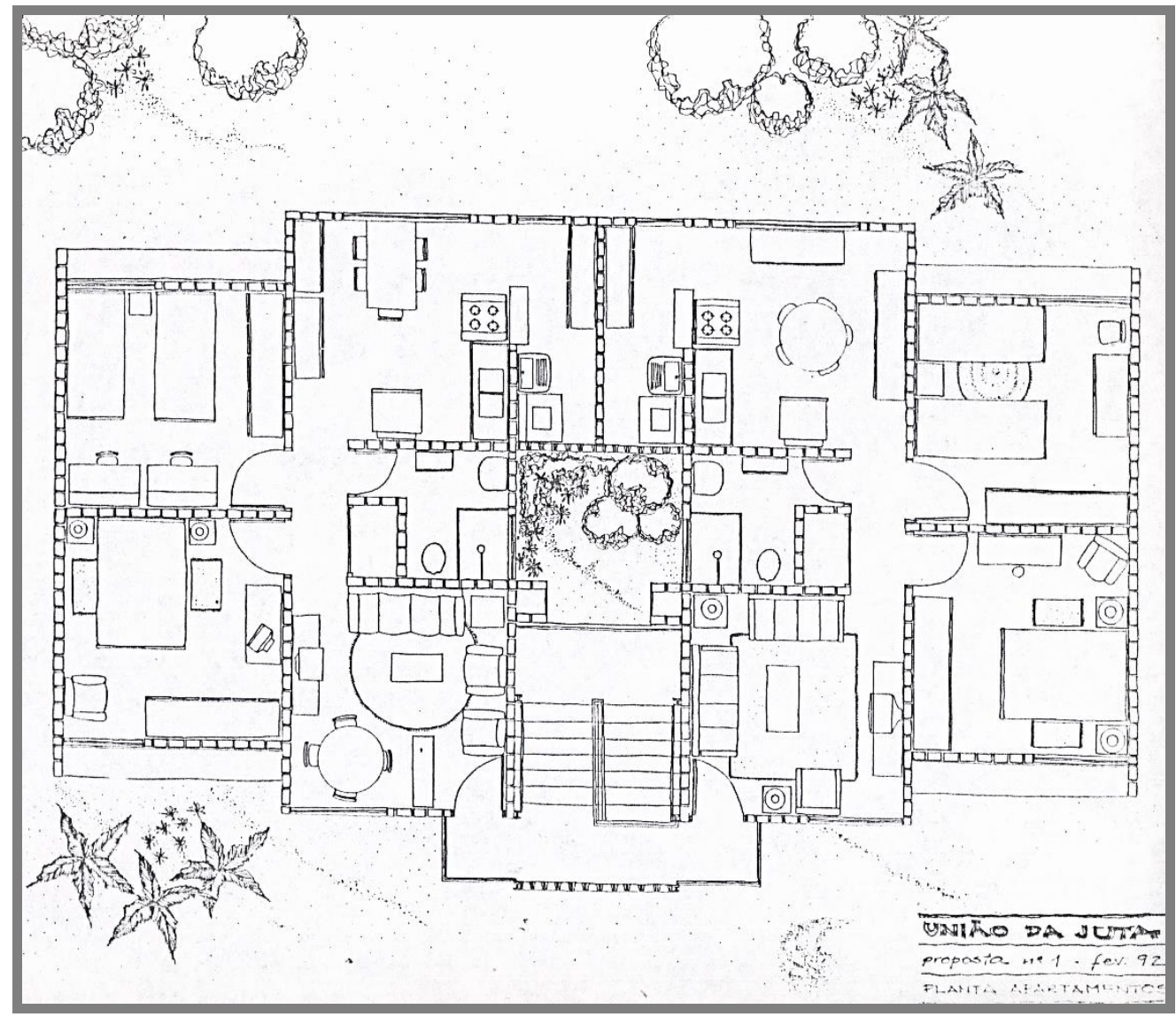

Figura 8| Planta humanizada, fev. 1992. Fonte: Acervo USINA.

Nos registros das reuniões realizadas entre a assessoria técnica e os futuros moradores também é possível observar detalhes do processo de discussão para a definição do projeto:

No final, discutimos porque não dá pra ser um apartamento enorme: custo! Cada metro quadrado custa muito caro. (...) Invertemos o caminho da proposta: primeiro, o apartamento e o prédio; depois discutiremos a proposta para o conjunto; por que só conseguimos agora, exatamente como é o terreno, o desenho de seus limites. (...) A partir do desenho apresentado, vamos levantar as dúvidas para que todos possam conversar com suas famílias e trazer, na próxima semana, as conclusões que nos permitirão desenvolver o projeto. (USINA, registro de Reunião União da Juta) 
Durante as discussões projetuais a assessoria trabalhava em cima das propostas dos moradores, conforme solicitações dos mesmos. Por fim, acabaram optando por três tipologias habitacionais distintas.

Estes fatores são bastante ilustrativos sobre a distinção existente entre um canteiro de obra convencional, onde geralmente as decisões são impostas e o regime de trabalho mais desgastante - muitas vezes por ter a remuneração dependente da produtividade - e um canteiro de um mutirão autogestionário.

Diante do exposto, acreditamos que o processo de elaboração do projeto arquitetônico do MUJ pode ser considerado um exemplo de enfrentamento e questionamento do paradigma de construção da habitação popular. Primeiro, porque desde o início, a sua elaboração aconteceu de maneira coletiva e, segundo, porque a Associação de Moradores negou-se a utilizar o projeto padrão da CDHU, não cedeu à pressão da instituição e contratou assessoria técnica externa.

Portanto, foi um trabalho que além de incentivar, também facilitou o acompanhamento do processo de planejamento e execução da obra pelos moradores. Da mesma forma, buscou estabelecer uma nova maneira de projetar e construir moradias para a população mais pobre, por meio da transferência, na medida do possível, de conhecimento técnico à população.

Em síntese, no que se refere à elaboração do projeto arquitetônico do MUJ, em quase todos os momentos a presença da assessoria técnica foi fundamental na orientação sobre as decisões que seriam tomadas. Vale destacar, que a assessoria prestada especificamente pela USINA é diferenciada, pois tem como princípio o estímulo à autonomia dos mutirantes. No que concerne à concepção de autogestão, a USINA, buscou oferecer aos mutirantes uma forma trabalho para além da participação na definição do projeto, ou seja, como uma experiência que engloba aspectos políticos, econômicos e sociais. Eles também 
incentivavam a compreensão das etapas da obra, do planejamento, administração e orçamento. Deste modo, poderiam ter uma visão mais abrangente sobre todo o trabalho que envolve o processo construtivo em canteiros de obras.

Em geral, nos programas habitacionais convencionais a participação não acontece sob esta perspectiva, quando ela acontece está restrita a simples votação de propostas pré-estabelecidas, não permitindo ao futuro morador opinar sobre sua habitação e/ou suas características, também não proporciona uma compreensão do processo construtivo e político da moradia popular. Da mesma forma, nas produções convencionais, a assessoria técnica não é colocada como parte importante para o desenvolvimento do processo.

Além dos aspectos já mencionados, a USINA prestou acompanhamento técnico à construção habitacional, o que foi essencial para a garantia de sua qualidade construtiva, bem como para a organização das famílias no canteiro de obras, que por sua vez, interferiu na qualidade do processo construtivo e do produto final: a moradia.

Ainda neste sentido, podemos afirmar que o projeto arquitetônico da Vila União da Juta questionou paradigmas existentes, primeiro pela forma de trabalho da assessoria técnica que buscou compartilhar conhecimentos em relação à técnica e a política. Além disso, também não se submeteu a todas as regras instituídas pela CDHU, como exemplo, elaboraram projeto próprio e não seguirem o modelo padrão da companhia. É neste contexto que afirmamos que o MUJ se constitui em uma experiência inovadora de construção de habitação social no país.

Nas discussões do projeto também planejaram creche, padaria e centro comunitário, assunto que será abordado na sequência. 


\subsection{Fazendo a casa: o Mutirão da União da Juta}

O início do trabalho em mutirão foi caracterizado pelos moradores como um evento que provocou movimentação diferenciada no bairro e despertou curiosidade daqueles que por ali passavam. Os moradores afirmaram que algumas pessoas pediam informações sobre o que era preciso ser feito para participar de processos de mutirão como aquele. Desta forma, a organização das famílias na construção de sua própria moradia, demonstrou legitimidade na esfera política local e provocou a renovação das forças para a luta por moradia.

Começaram o mutirão com a construção do canteiro de obras que, posteriormente, seria utilizado como centro comunitário. Em seguida, construíram a casa do vigia e o galpão para almoxarifado (Figuras 9 e 10). O início dos trabalhos foi um momento de inúmeras dificuldades e de solidariedade dos vizinhos mais próximos, sobretudo os participantes do mutirão 26 de Julho, que nesta época, já estava em desenvolvimento.

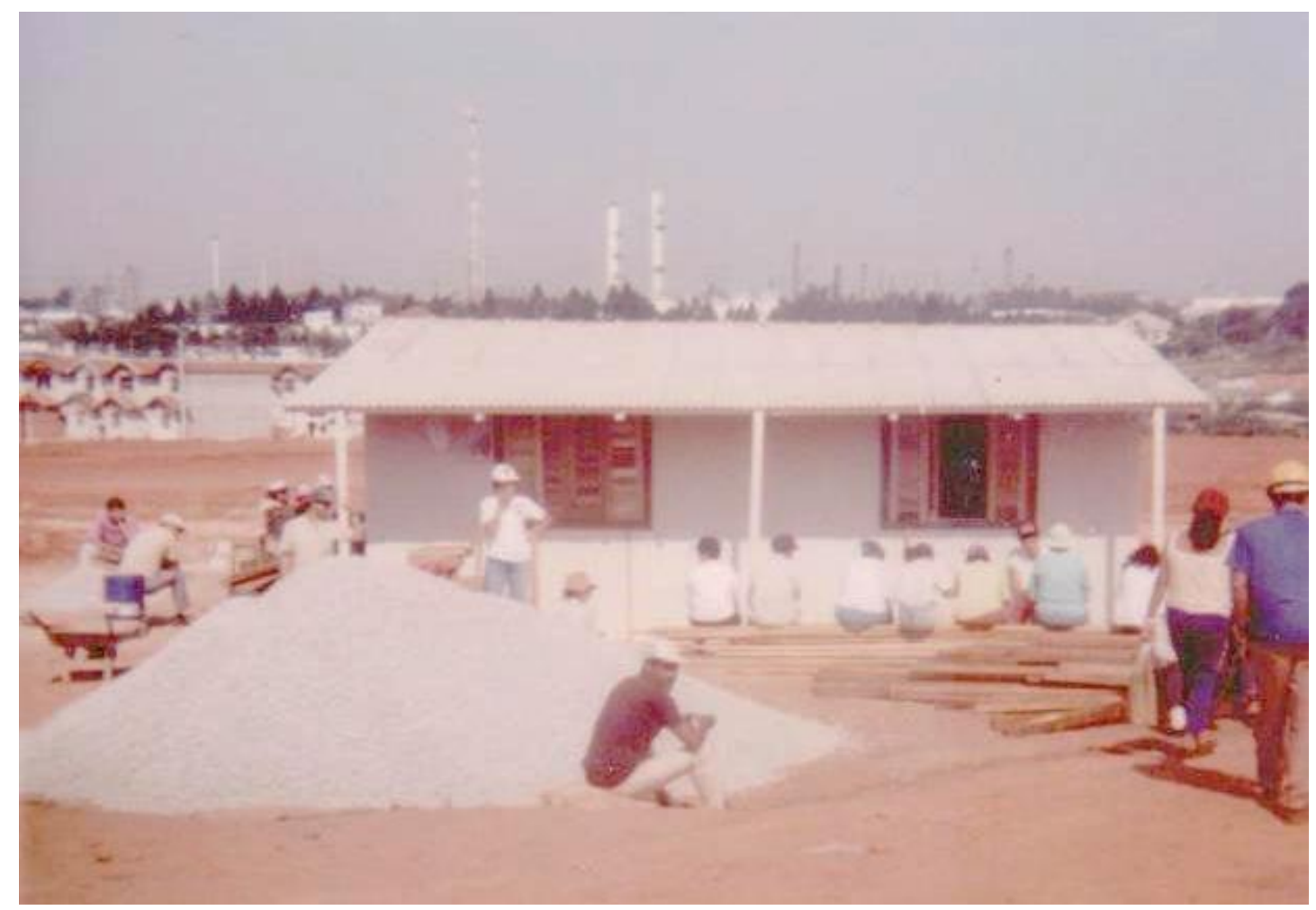

Figuras 9 | Início das obras no Mutirão da Juta Fonte | acervo pessoal de morador. 
Além dos problemas infraestruturais ${ }^{63}$ para acesso a água, energia elétrica e rede de telefonia - recursos básicos para a permanência no local da obra por longos períodos -, outra dificuldade foi a heterogeneidade existente entre os participantes do mutirão. Eram pessoas vindas de diferentes locais e pertencentes a diversos grupos sociais: moradores de cortiços, de casas de aluguel, de regiões ainda mais periféricas, do centro da cidade; operários semi-qualificados empregados da construção civil, trabalhadores domésticos; homens e mulheres; jovens e idosos; sujeitos que possuíam diferentes níveis de compreensão da proposta de trabalho em mutirão.

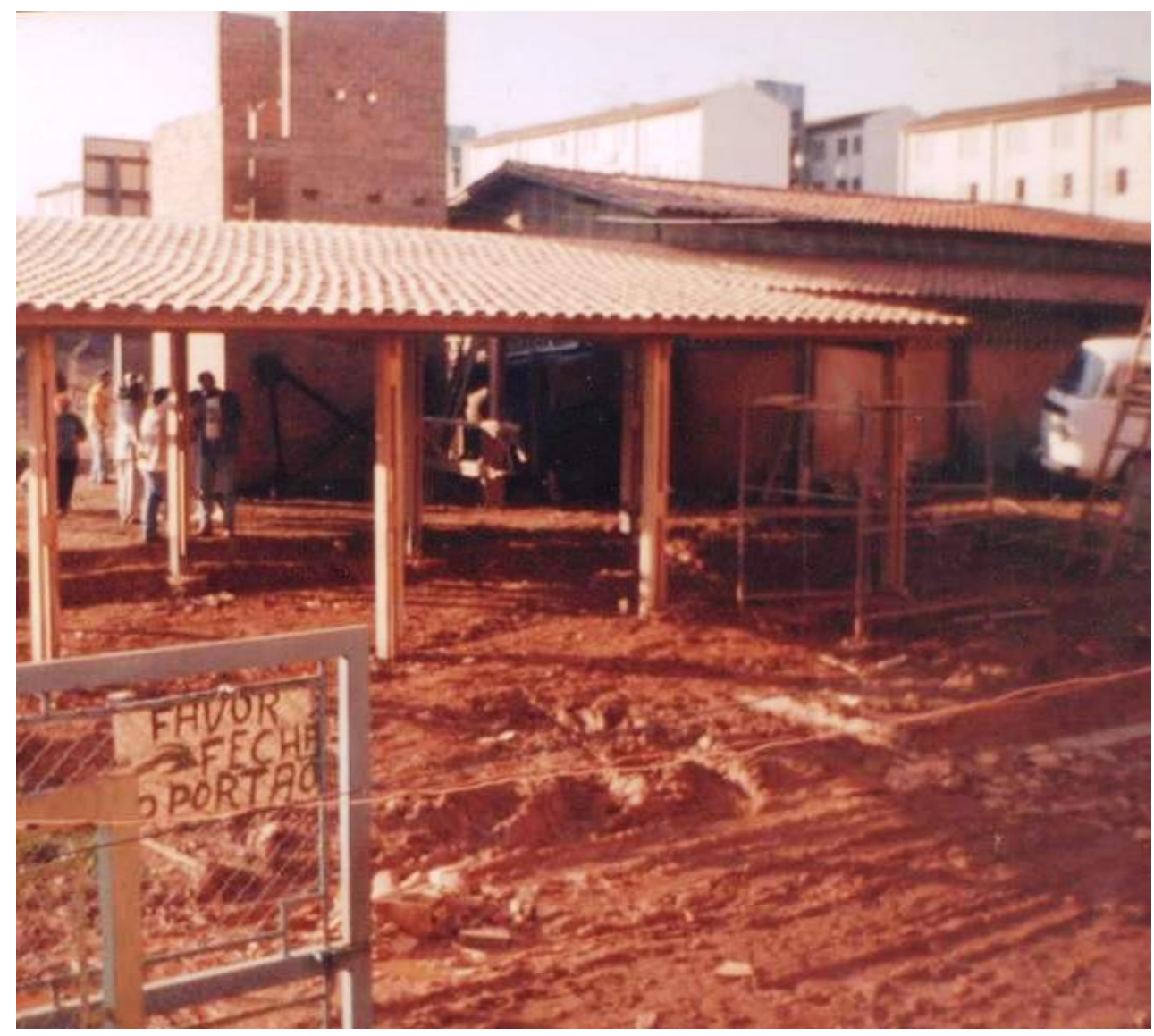

Figuras 10| Construção do centro comunitário no Mutirão da Juta Fonte | acervo pessoal de morador.

${ }^{63}$ As redes condominiais de drenagem de água, esgoto e obras de terraplanagem, guias, sarjetas e pavimentação do sistema viário tiveram os seus custos inseridos sobre o valor do financiamento da unidade habitacional. 
A solução encontrada pela assessoria técnica foi dividi-los em grupos de obra e comissões, conforme as suas potencialidades e necessidades. Havia momentos em que esses grupos eram desmembrados, reunidos, tinham suas funções alteradas, trabalhavam em conjuntos ou separadamente, conforme o andamento da obra64. Durante a semana, a USINA montava as chamadas "frentes de trabalho", planejando as tarefas a serem executadas no final de semana pelas equipes de trabalho, de acordo com o cronograma de obras.

As mulheres mutirantes tiveram papel fundamental, tanto no canteiro de obras como na gestão dos equipamentos comunitários. Como elas formavam um grupo expressivo, ou seja, estavam em maior número, foram divididas entre as mais velhas (que trabalhavam na cozinha e na destruição de água no canteiro) e as mais jovens, que ajudavam no serviço mais braçal (por exemplo, o transporte de materiais), algumas executavam serviços que exigiam maior cuidado, como acabamentos e detalhes da construção.

\section{Em todos os mutirões com autogestão, já se sabe que é a mulher a cabeça da história, se fosse esperar pelos homens ninguém teria casa, a maioria é mulher. Então, elas traziam as crianças, colocavam ali na creche, uma ou duas ficavam tomando conta, enquanto elas trabalhavam. (Entrevistada D, MUJ, entrevista à autora, abril. 2012).}

Entre os homens destacaram-se diferentes níveis de conhecimento sobre construção civil, o que influenciou sua ocupação no mutirão, por exemplo: os que já eram pedreiros e carpinteiros permaneceram nestas funções durante todo o período do mutirão; enquanto aqueles que possuíam pouco ou nenhum conhecimento sobre construção civil foram distribuídos em diversas tarefas, diretamente relacionados à obra ou a assuntos administrativos e contábeis.

\footnotetext{
${ }^{64}$ Encontram-se listadas no anexo 3, os principais grupos de tarefas e comissões com as respectivas funções exercidas no mutirão da Juta.
} 
Um passo importante para o bom andamento do mutirão foi a implantação da cozinha comunitária, pois fornecia alimentação fresca e de boa qualidade, ao mesmo tempo em que liberava as mulheres de idade mais avançada do trabalho pesado no canteiro. A equipe que compunha a cozinha comunitária também se organizava segundo uma lógica autogestionária, responsabilizando-se, pela arrecadação de recursos, compra dos alimentos, preparo e distribuição das refeições.

Ainda no que se refere à distribuição de tarefas e a participação dos diversos sujeitos no MUJ, tendo como princípios a colaboração e a valorização das potencialidades individuais em favor do interesse coletivo, vale destacar um fato que ocorreu durante a obra. De acordo com a assessoria técnica, na etapa de assentamento de blocos cerâmicos era necessário manter a superfície molhada com água para recebimento da argamassa. Uma mulher observou a dificuldade na execução da tarefa e sugeriu que o procedimento fosse realizado com um bule grande utilizado na cozinha comunitária. O bule permitia o armazenamento de maior quantidade de água, reduzindo a necessidade de abastecimento contínuo do recipiente e facilitando a aplicação de água devido ao formato do utensílio doméstico. De forma geral, a solução criativa encontrada acelerava a execução do trabalho e reduzia o esforço físico.

Esta experiência demonstra que a construção coletiva muitas vezes pode produzir elementos bastante interessantes para o desenvolvimento da obra. Demonstra ainda, como muitos procedimentos podem ser modificados e construídos coletivamente conforme o andamento do processo, ou seja, conforme afirma Ferro (2004), não há melhor forma de experimentar as coisas que não seja realizando. Assim, os atores do processo foram aprendendo e trocando conhecimentos ao longo da obra.

É interessante notar que o trabalho executado em dias úteis foi bastante distinto do trabalho realizado nos finais de semana, isto é, 
durante a semana a dinâmica do mutirão era parecida a um canteiro de obras convencional, porque os trabalhadores eram contratados. Estas contratações foram necessárias, porque se o trabalho fosse realizado apenas nos finais de semana não cumpririam o cronograma de obras, o que comprometeria a liberação de verbas pela CDHU, uma vez que, esta só ocorria após medições mensais realizadas no acompanhamento da obra pela instituição.

A equipe contratada possuía direito de tomar decisões coletivas, principalmente àquelas referentes ao regime de contratação e remuneração. Foi dada preferência para a contratação de desempregados do próprio mutirão que já tinham experiência com construção civil, trabalhadores autônomos e pequenos empreiteiros.

A contratação foi um mecanismo de apoio à obra, pois além de assegurar a continuidade no ritmo do trabalho permitiu a economia de esforço físico dos mutirantes e de tempo, por exemplo, no caso das lajes, citado anteriormente. Conforme informações fornecidas pelos moradores em entrevistas, os dias de concretagem das lajes foram dias de trabalho muito árduo, que foram amenizados com a contratação de serviços de usinagem e bombeamento de concreto.

A Vila União da Juta só foi concluída seis anos após o início das obras, contrariando as primeiras previsões realizadas que estimavam 12 meses de trabalho. Ocorreram sucessivas dificuldades para o andamento da obra, conforme consta no Relatório de Solicitação de Recursos Extraordinários, encaminhado pela Associação União da Juta para a CDHU:

- chuvas no $2^{0}$ semestre de 1993

- consequente atraso nas obras de terraplanagem (conclusão apenas em novembro de 1993)

- conflituoso processo de aprovação dos projetos (aprovados apenas no início de 1995)

- advento do Plano Real e aplicação de redutor (cf. MP) ao valor do contrato numa fase completamente desfavorável (contratação de escadas e início de alvenarias). 
A Associação foi, sistematicamente, acumulando perdas e prejuízos: os valores medidos pagos não mais remuneravam adequadamente os serviços efetivamente executados.

Outra dificuldade para a conclusão da obra foi a saída da assessoria técnica USINA, resultado de uma manobra do governo estadual, através da CDHU que, segundo a Associação, pressionou os moradores nos seguintes termos: ou forneceriam os recursos e para terminarem a obra com o apoio do governo ou ficariam com a assessoria técnica e sem financiamento do governo. A maioria das famílias dependia de financiamento e desejava deixar de pagar aluguel, por isso optaram pelo fim da obra, sem a USINA.

Essa ação do governo foi uma tentativa de dissolver a autogestão estabelecida na parceria entre o MUJ e a assessoria e assim, atrelar os mutirantes aos interesses políticos governamentais. No entanto, a CDHU encontrou inúmeras dificuldades para administrar e tocar a obra e assim, por forte pressão da Associação de moradores, definiu-se que a assessoria técnica (USINA), voltaria para finalizar a obra.

Assim, no final do ano de 1998 foi realizada a inauguração da Vila União da Juta. Os próprios moradores organizaram uma festa, onde reunidos comemoraram a conquista do direito à moradia, sem a presença de políticos com intenções paternalistas, que ainda hoje buscam reproduzir uma prática já tradicional presente no imaginário popular: o sorteio e entrega das chaves de casas populares.

No entanto, o poder público, através da CDHU, também efetuou uma cerimônia de inauguração, ato que foi lembrado pelos moradores como um "gesto a contra gosto", já que na ocasião as moradias foram anunciadas como uma obra realizada pelo governo estadual. A análise feita pelos participantes do MUJ demonstra, mais uma vez, a noção de autogestão que foram capazes de construir e a tomada de consciência que apresentaram ao final do processo. Também pode indicar a 
consciência de que a moradia só foi conquistada devido às pressões e mobilizações efetuadas por meio dos movimentos sociais:

Nós sempre ouvíamos deles (CDHU) que nós não estávamos construindo casa pra pobre, o tamanho dos apartamentos é para a classe média, não para pobre. Mas nós mostramos para eles que a gente, mesmo pobre, tinha que ter uma moradia digna do jeito que a gente tem hoje65. (Entrevista com moradora, abril de 2012). (Moradora do MUJ, entrevista à autora, abr. 2012).

Portanto, o MUJ confirma a premissa inicial da dissertação de que os programas habitacionais podem atingir as faixas de rendas menores, mesmo que historicamente isto não esteja acontecendo. Também demonstra ser possível a criação de melhores condições habitacionais, adequadas às demandas populares e, sobretudo, diferenciadas daquilo que se convencionou chamar de Habitações de Interesse Social (HIS). No próximo item verificaremos quais foram os elementos projetuais utilizados no MUJ, que nos permitem tal afirmação.

\subsection{Aspectos projetuais do mutirão união da juta depois de vinte anos de implantação.}

A questão da moradia popular não se limita a resolução do projeto de arquitetura, ela vai muito além e envolve questões mais amplas. Conforme apontamentos anteriores, as dificuldades enfrentadas no desenrolar do MUJ, resultaram, muito mais, de entraves políticoinstitucionais, do que, por uma ausência de solução arquitetônica.

Desta forma, consideramos fundamental apresentar as opções projetuais, tecnológicas e construtivas, que foram sugeridas, discutidas e

65 Para Ferro (2004): "O preconceito subjacente a esta associação talvez seja de considerar que os pobres tem que se 'virar' com sobras e coisas elementares quando cuidam de si, como o sistema os obriga - deixando a produção séria para gente séria. $O$ miserabilismo é coisa de rico. Se for possivel, não há porque evitar soluções técnicas avançadas nos canteiros dos autoconstrutores: o pólo hegemônico aqui não são as forças e meios de produção, mas, repito, as relações de produção". 
construídas com os mutirantes da União da Juta e que resultaram em um projeto arquitetônico diferenciado. Acreditamos que não há como pensar soluções para a questão da habitação contemporânea sem um resgate histórico de exemplos reais e sem uma compreensão dos elementos que fizeram parte desse projeto de arquitetura.

Também consideramos necessário desnaturalizar a atual forma de produção habitacional - caracterizada por uma "tipificação66", produção em larga escala, localização periférica, unidade habitacional de tamanho reduzido, baixa qualidade construtiva - e desta forma, mostrar que há na história da arquitetura exemplos de projeto habitacional que pode inspirar mudanças no quadro atual.

Conforme Ferreira (2012), "casas que não permitem o convívio familiar, que não oferecem espaços para a reunião da família, brincadeiras e estudos das crianças, não criam condições de desenvolvimento pessoal, familiar e coletivo". Neste sentido, não há como negar a necessidade de se pensar em projetos de habitação de interesse social mais adequado à demanda. A Vila União da Juta pode nos indicar caminhos interessantes, em termos arquitetônicos, para a produção de moradia popular.

\footnotetext{
66 O termo Tipificação é utilizado por Pulhez (2010) para designar uma padronagem do habitat popular, referenciada por um tipo projetual híbrido, que parece consolidar-se como uma combinação que agrega os pressupostos disciplinares do período higienista àqueles da industrialização e economia de meios consagrados, ao menos em discurso, a partir da criação do BNH, regulando e instruindo de forma estratégica os saberes sobre à casa popular, alinhando desenho e processo produtivo num esquema que, na verdade, chega mesmo a gerar uma estética que lhe é própria e que se torna característica da promoção estatal de habitação para os mais pobres na cidade brasileira. A autora vai além e afirma que a ideia de racionalidade técnica aí presente se transmuta em um padrão de pensamento e julgamento que permite justificar e legitimar a reprodução de baixos padrões habitacionais como espaço próprio de moradia dos pobres.
} 
Novamente, é preciso salientar que os elementos projetuais do MUJ não devem ser analisados isoladamente, tendo em vista, que ele compõe um processo de produção habitacional específico, opera sob condições e padrões distintos, em mercados e contextos diferentes. Assim, não podemos reduzi-lo a padrões de medição de desempenho e indicadores de qualidade como, por exemplo, volume de produção e tempo de execução do projeto. Acrescentamos que é necessário considerar outras dimensões possíveis, distintas das Avaliações Pós-Ocupação (APO) ${ }^{67}$, ampliando a abrangência da temática por meio do contexto social e político do período.

Portanto, o projeto da Vila União da Juta, pode suscitar algumas questões: Quais as soluções projetuais que nos permitem considerá-lo como um projeto emblemático? Podemos almejar um futuro melhor para a produção de moradia popular? Tais questões não possuem uma única resposta por isso merecem ser discutidas na tentativa de contribuir para o avanço do debate.

\subsubsection{Inserção urbana}

A Vila União da Juta está localizada na Zona Leste 1, região periférica, limítrofe entre o município de São Paulo e Santo André, pertencente a Subprefeitura da Vila Prudente/Sapopemba (ver anexo 2).

No início do mutirão, essa região caracterizava-se como fronteira do tecido urbano, onde não havia nenhum sinal de urbanização, com total carência de equipamentos e serviços públicos.

Nos últimos 20 anos, esta área foi ganhando materialidade, primeiro com a chegada das habitações, depois com os equipamentos e serviços

67 Ornsten e Romério definem Avaliação Pós-Ocupação como sendo um conjunto de métodos e técnicas que visam avaliar o ambiente construído, segundo as suas características construtivas, de conforto ambiental, funcional, estéticos, comportamental e organizacional. Ver maiores detalhes em: ORNSTEIN, Sheila Walbe; ROMÉRIO, M. Avaliação Pós-Ocupação do Ambiente Construído. São Paulo, Studio Nobel/EDUSP, 1992. 
urbanos e hoje representa a longa luta comunitária, não só por habitação, mas também por sua integração à cidade. Atualmente, a Fazenda da Juta, área onde foi implantada a União da Juta, transformou-se em uma região provida de infraestrutura, serviços e equipamentos comunitários (de educação, saúde e lazer) necessários para a reprodução da vida urbana (ver Figura 11).

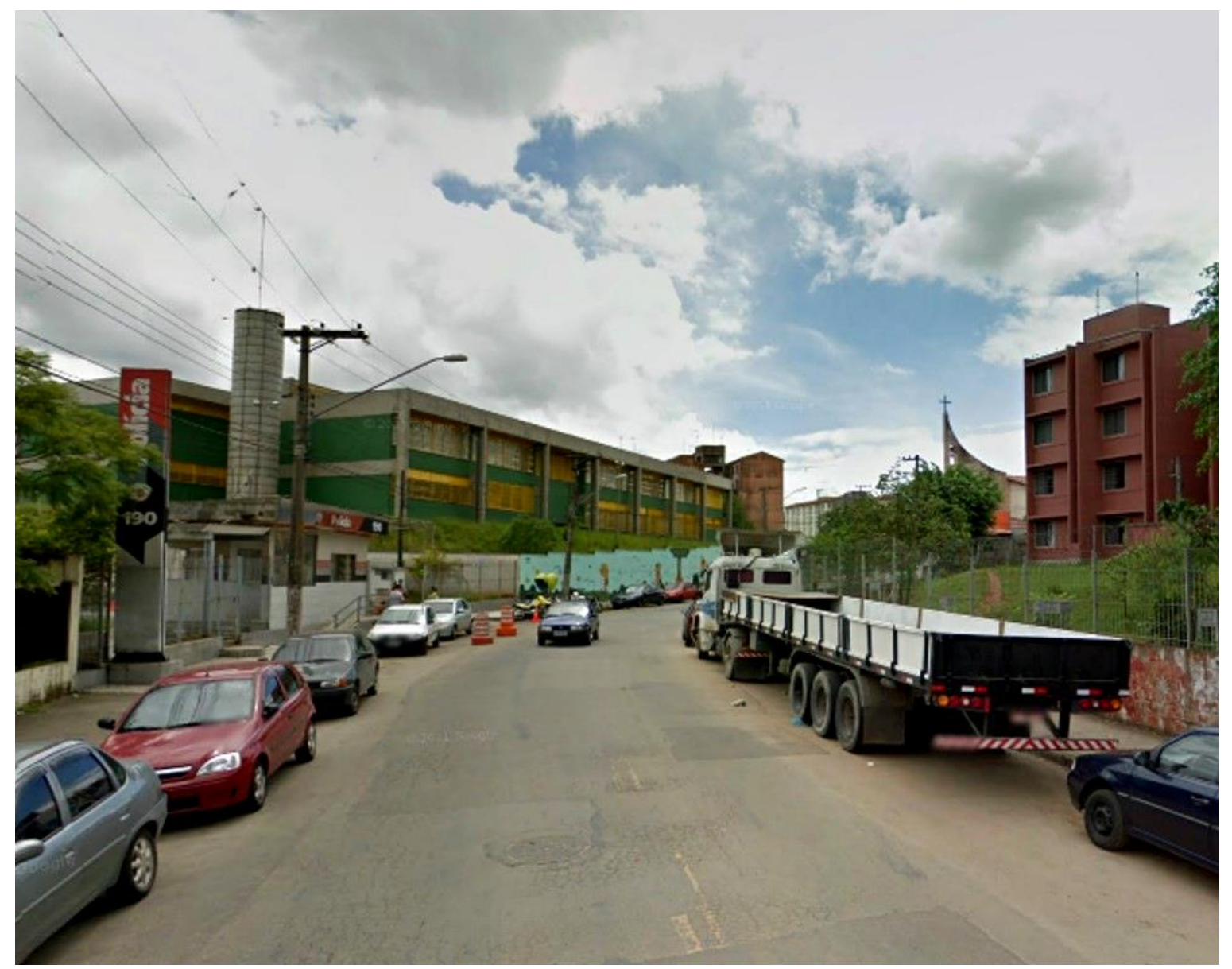

Figura 11| Foto da rua onde foi implantada a Vila União da Juta - a direita, o conjunto habitacional e a esquerda, posto policial e escola de ensino médio.

Fonte | Google maps, 2013

Oficialmente, a Vila União da Juta recebeu da CDHU68, a denominação de Itaquera B-4. O conjunto localiza-se em uma região com paisagem predominantemente marcada por uma concentração de

68 Esta denominação e numeração também são utilizadas pela CDHU para outros conjuntos habitacionais implantados na região - Itaquera B4, Itaquera B5, Itaquera B6, etc. Segundo Miagusku (2008), essas denominações já foram referidas por um jornalista como um "campo de concentração" (GASPARI, 22/05/1997). 
conjuntos habitacionais populares. Em sua maioria, são edifícios verticais de quatro pavimentos, com tipologia padrão para habitação de interesse social definida pela CDHU69. As chamadas "tipologias em H" são representadas por dois edifícios lineares idênticos implantados paralelamente e conectados pela escada, que faz a circulação vertical e dá acesso às habitações (ver figura 12).

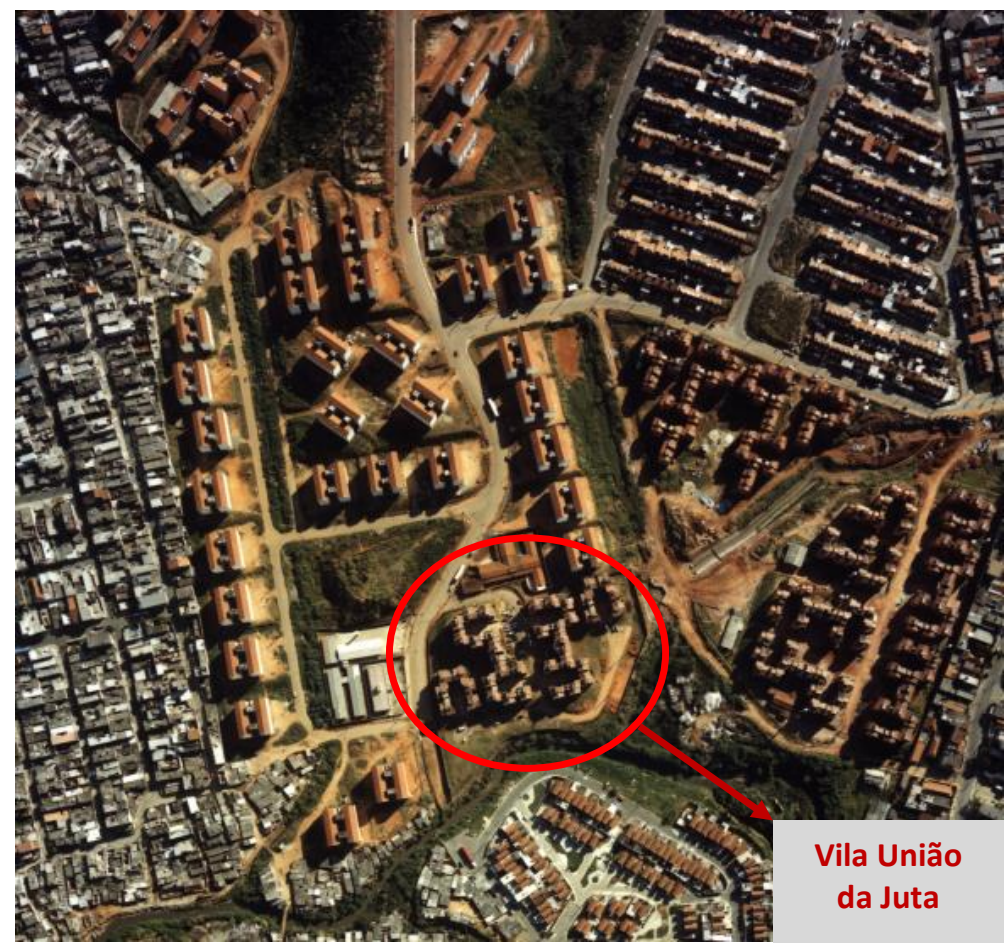

Figura 12| Foto aérea da região de implantação da Vila União da Juta.

Fonte | Acervo USINA

Em contraste com os conjuntos habitacionais do entorno, a Vila União da Juta possui um valioso significado urbano por se destacar na paisagem, atribuindo nova vitalidade para a região e resgatando valores importantes como a diversidade urbana (Figura 13).

69 Para obter maiores detalhes sobre as tipologias padrão conferir Manual Técnico de Projetos da CDHU. Disponível em: <http://www.cdhu.sp.gov.br/download/manuais-ecadernos/manual-de-projetos.pdf>. Acesso em: ago. 2012. 


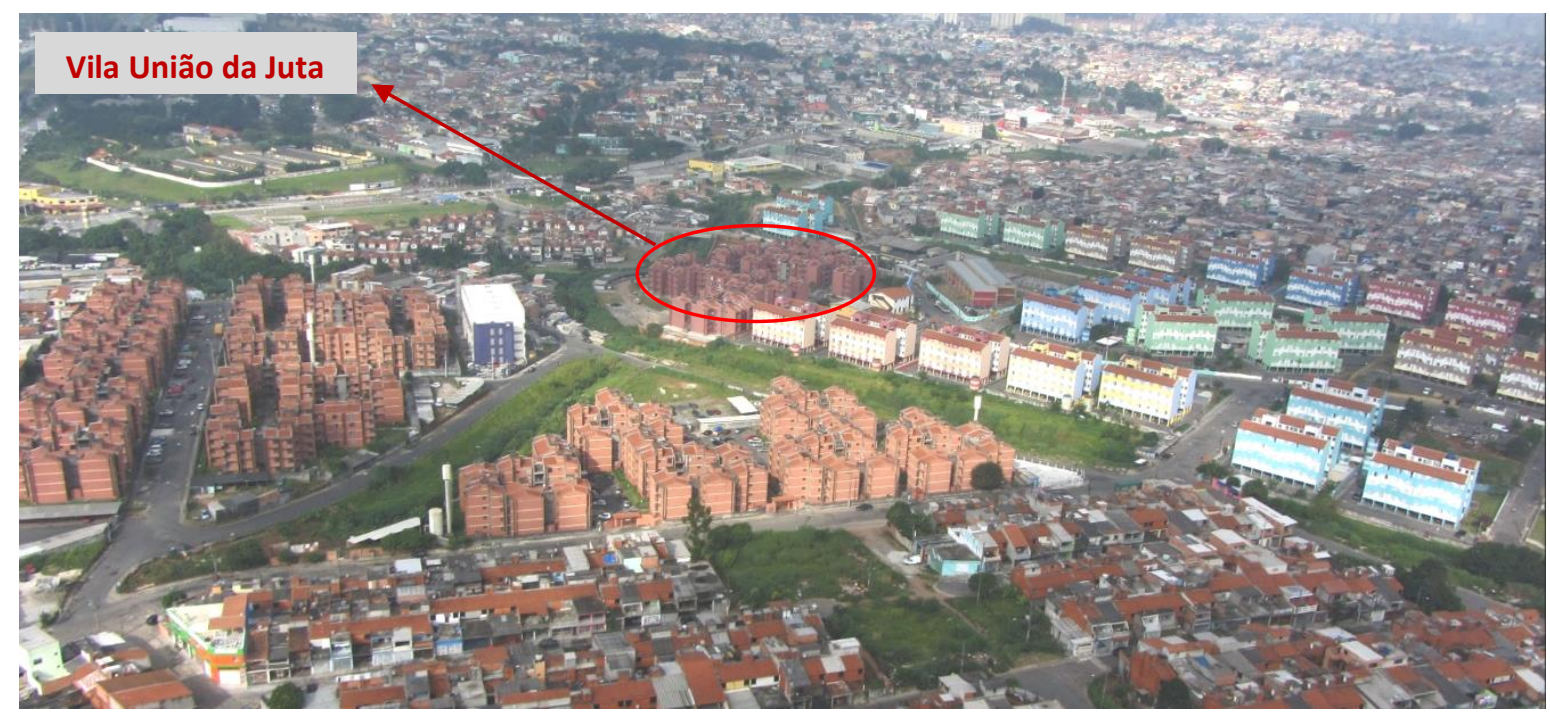

Figura 13 | Conjuntos habitacionais em Sapopemba e em destaque a Vila União da Juta.

Fonte | sistemapri.com.br.

Org.| Fabrícia Mitiko Ikuta

\subsubsection{Implantação urbana}

A área de implantação da Vila União da Juta possui um total de 49.909,55 $\mathrm{m}^{2}$, onde foram construídos os edifícios habitacionais, centro comunitário, creche, padaria comunitária e a sede da Associação de Moradores (ver figura 14). A Vila União da Juta possui população estimada em 480 habitantes e densidade média de aproximadamente 579 hab/ha. Vale ainda ressaltar a importância de se ter densidades médias e altas, para o atendimento do maior número possível de famílias. Além disso, em termos urbanos as densidades altas são mais adequadas para cidades grandes onde o valor da terra pode ser mais elevado.

O sistema viário é composto por uma via local - com $7 \mathrm{~m}$ de largura, sendo $5 \mathrm{~m}$ para rolamento e $1 \mathrm{~m}$ de calçada para cada lado -, que dá acesso ao interior do conjunto e auxilia a circulação de veículos (Ver figura 15). Esse traçado viário possui um custo de infraestrutura reduzido, é altamente econômico e possibilita alto grau de segurança para os pedestres que podem trafegar quase que livremente, pois o trânsito interno ao condomínio é bastante reduzido, os carros trafegam com uma 
menor velocidade e não existe cruzamentos internos perigosos. As crianças também podem se apropriar da rua, criando uma vida comunitária mais intensa. Segundo memorial descritivo, o conjunto possui 54 vagas de estacionamento, número que segue a relação de 1/3 do total de apartamentos (160 unidades habitacionais), conforme era previsto em legislação municipal.

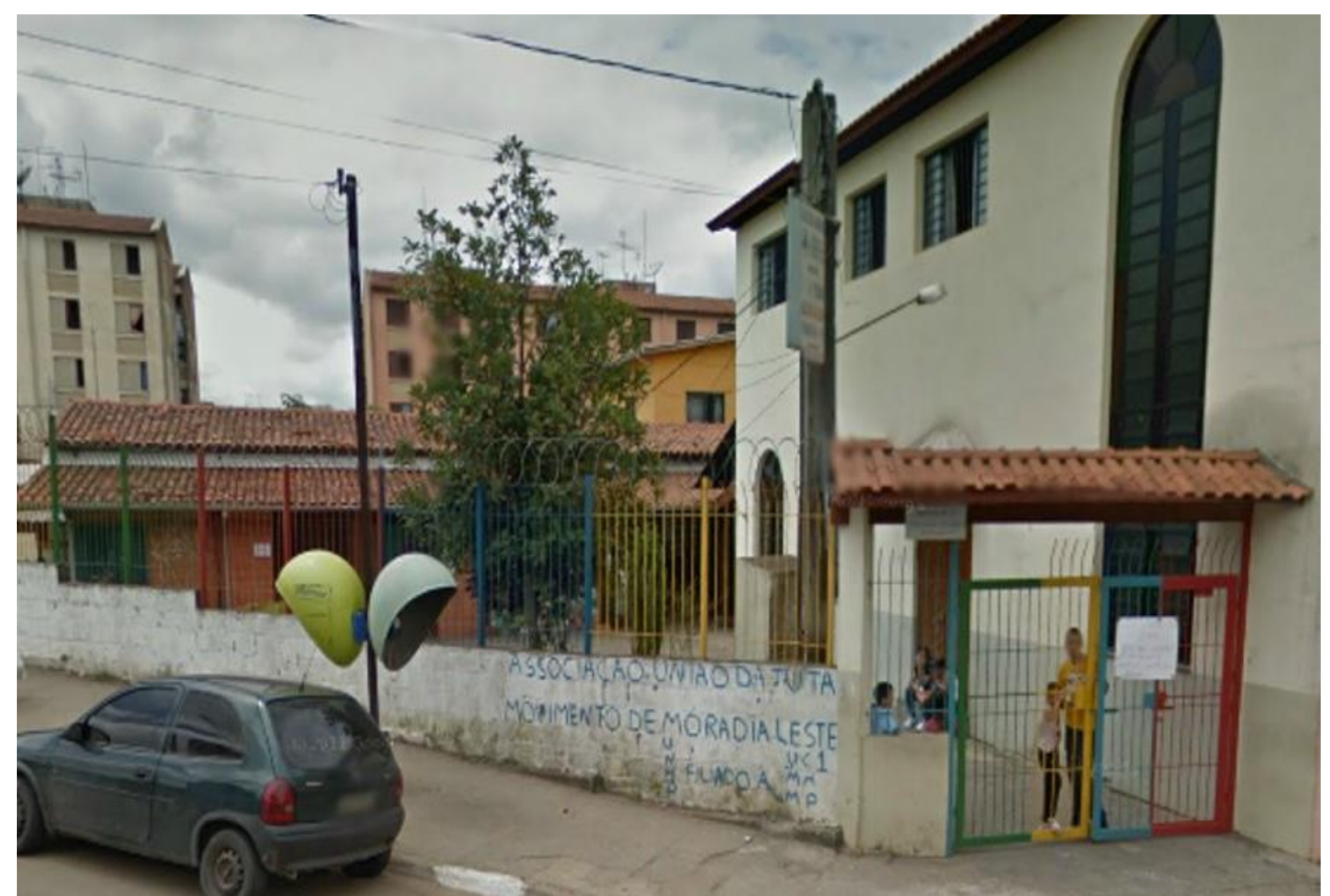

Figura 14| Sede da Associação de Moradores, creche e Igreja do MUJ. Fonte | sistemapri.com.br.

Org. | Fabrícia Mitiko Ikuta

Quanto à apropriação do sítio natural, percebemos que procurouse respeitar as características do terreno, executando movimentações de terra apenas em áreas imprescindíveis. Em memorial descritivo do anteprojeto de urbanização da União da Juta é destacado a ausência de cadastro atualizado dos elementos cartográficos, a falta de detalhamento e definição imprecisa dos limites das áreas fornecidos como base projetuais pela CDHU que acabaram por impossibilitar a adequação mais precisa das edificações à topografia do terreno. 


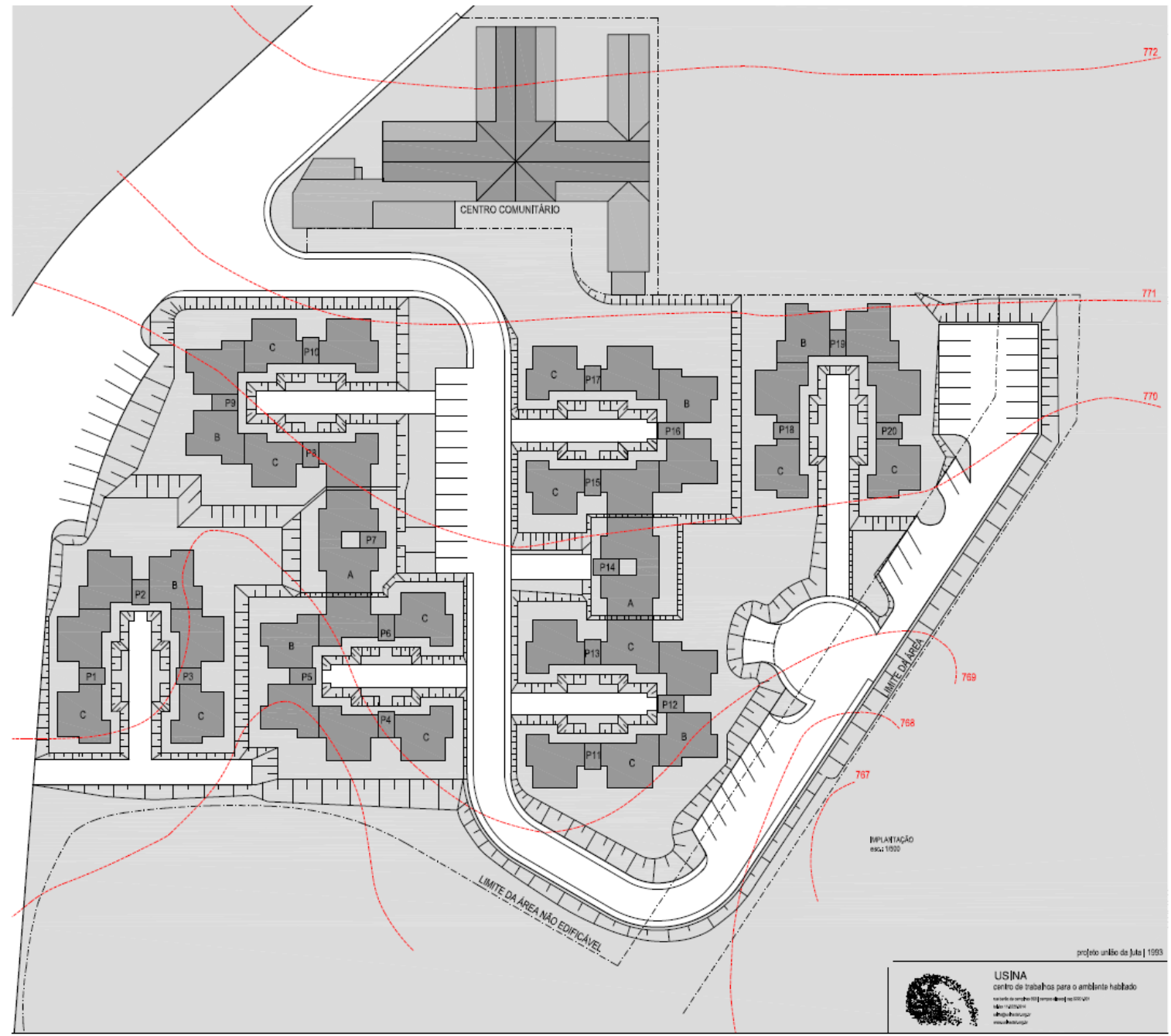

Figura 15| Implantação da Vila União da Juta.

Fonte | acervo USINA.

Mesmo diante das dificuldades o projeto de implantação dos edifícios da Vila União da Juta, possui um arranjo diferenciado e bastante interessante do ponto de vista arquitetônico e também como contraponto a tipologia "padrão H" sugerida como projeto da CDHU para habitação de interesse social.

\subsubsection{Unidade de vizinhança - Quadra}

Na Vila União da Juta, a disposição dos edifícios rompem com o parcelamento tradicional - lotes retangulares, perpendiculares às vias públicas -, sugerindo novos arranjos espaciais e novas possibilidades de ocupação da quadra. 


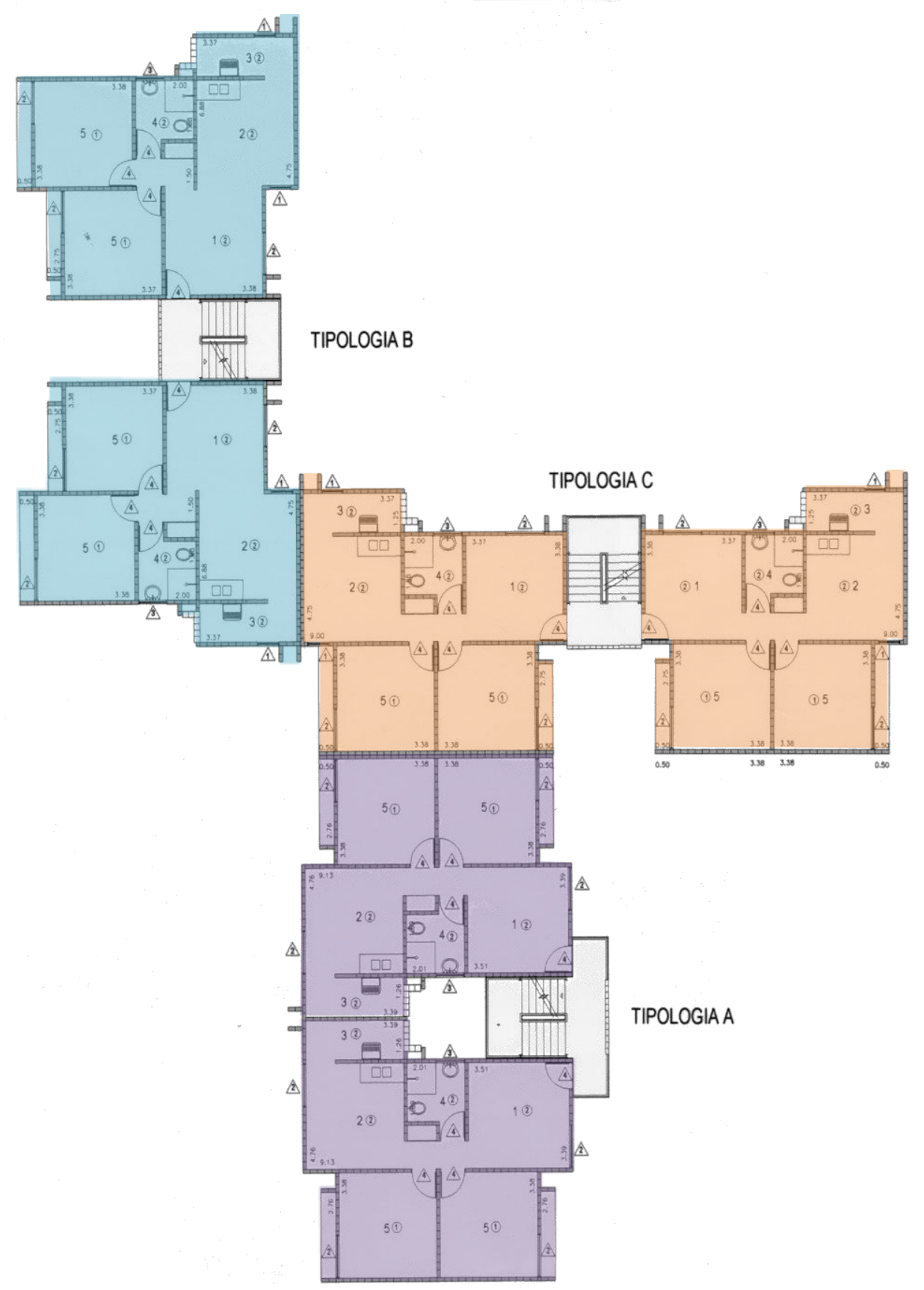

Figura 16| Geminação e articulação das unidades habitacionais Fonte | acervo USINA Organização| Fabrícia Mitiko Ikuta

Podemos destacar dois importantes aspectos do arranjo espacial: as articulações entre os espaços construídos e as possibilidades diversas de geminação e articulação das unidades habitacionais vão formando os edifícios e compondo um traçado de quadra aberta diferenciado (Figura 16). 


\subsubsection{O conjunto habitacional}

A União da Juta possui um total de 160 unidades, dispostas em 20 blocos, agrupados em conjuntos de três. Essa solução mostrou-se bastante interessante, porque eliminou os extensos corredores internos existentes em grandes conjuntos habitacionais.

Esse novo arranjo dos edifícios, permitiu a formação de pátios internos (Figura 17), destinados à circulação de pedestres, acesso às habitações e lazer. Para Arantes (2007), "os edifícios articulam-se entre si, formando espaços ora mais privativos, como pequenas vilas de acesso, ora mais abertos, criando uma urbanidade pouco encontrada em conjuntos habitacionais". Neste sentido, a proposição de implantar os edifícios elevando-os a $1,50 \mathrm{~m}$ do nível do piso externo, permite a formação desses pátios, circundados pelos edifícios, mas conectados visualmente aos apartamentos. A elevação do nível do piso também possibilitou um isolamento visual e físico para as unidades habitacionais térreas, garantindo maior privacidade e segurança.

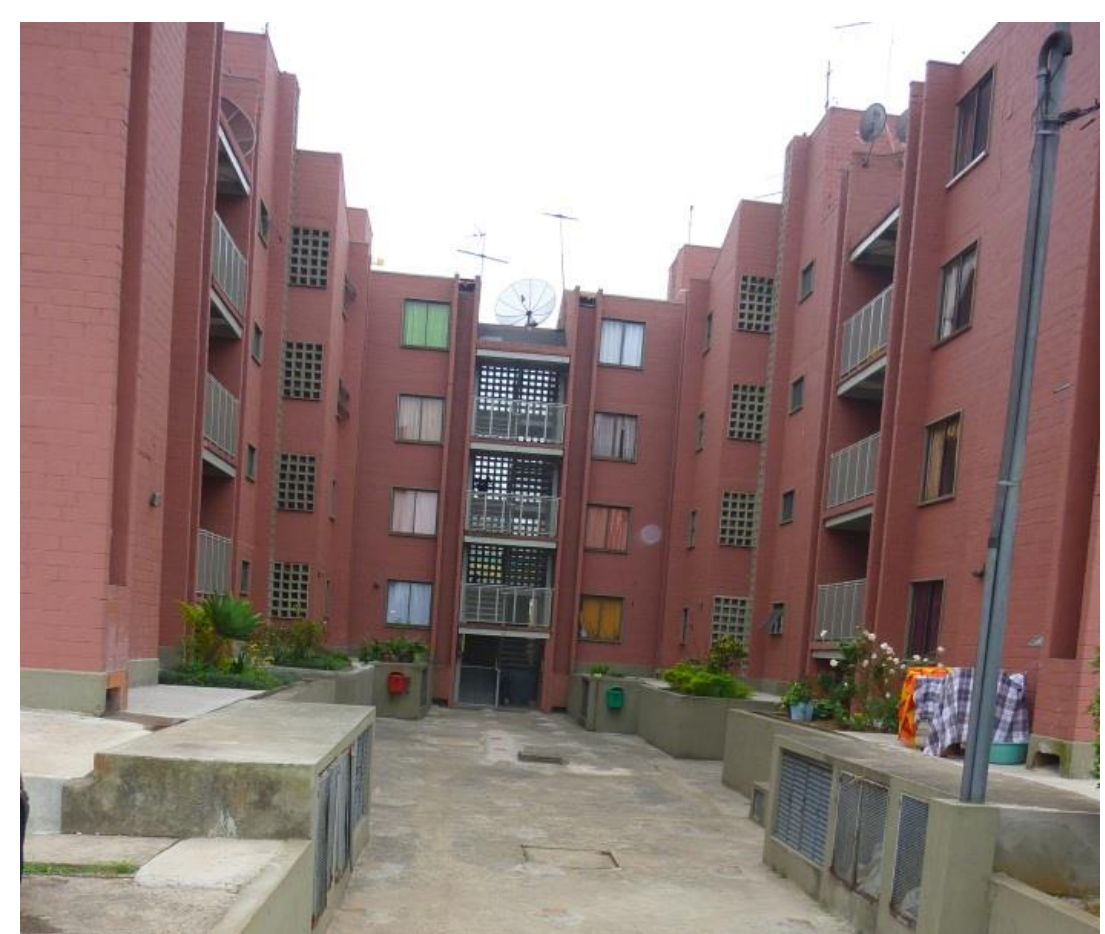

Figura 17| Pátio interno formado por novos arranjos entre os edifícios. Fonte | Fabrícia Mitiko Ikuta 
O projeto arquitetônico do MUJ possui soluções tecnológicas inovadoras para o setor de construção de moradia popular. A primeira delas caracteriza-se pela composição bastante singular de um sistema construtivo híbrido baseado na utilização de alvenaria estrutural e escadas metálicas ${ }^{70}$. O uso do bloco cerâmico estrutural dispensa a utilização de vigas e pilares e também reduz grande parte de um trabalho braçal pesado que uma solução contrária exigiria.

O uso das escadas em torres metálicas (Figural8) possibilitou duas vantagens muito significativas em termos de redução do trabalho dispendioso que a construção civil impõe: quando as torres foram instaladas no início da construção serviram de gabarito para obra, ou seja, auxiliaram na definição do traçado e no controle da altura máxima dos edifícios. Ao mesmo tempo também foram utilizadas como andaimes, para transporte seguro de pessoas e de materiais. Conforme relato da própria assessoria técnica USINA esta solução acabou sendo utilizada também em outros mutirões da capital paulista.

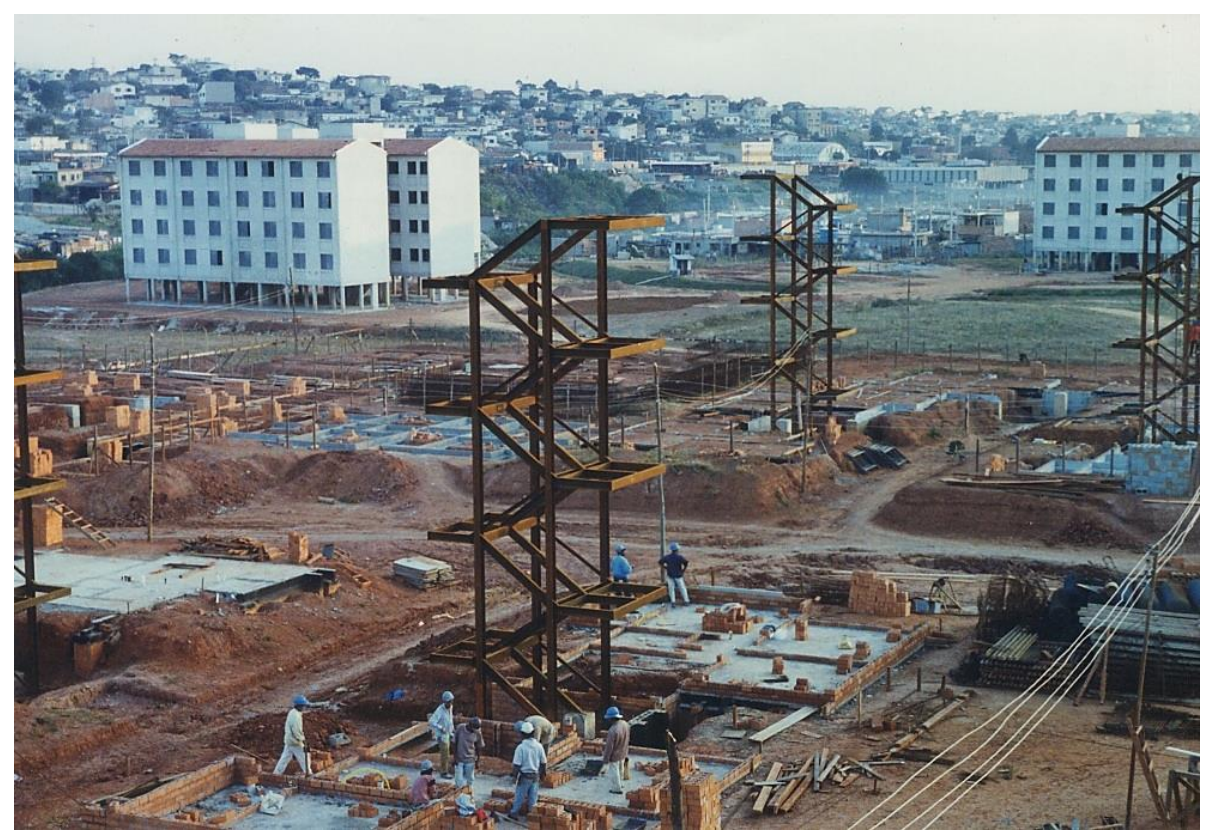

Figura18| Escadas metálicas servindo como gabarito e andaimes. Fonte | acervo USINA.

70 Para Ferro (2004), a mistura de tecnologia avançada (estrutura metálica) com procedimentos bastante primitivos, rompe com a associação comum entre tais canteiros e pobreza técnica. 
Os moradores e a assessoria técnica afirmaram que a decisão por deixar o bloco cerâmico aparente levantou uma discussão sobre o trabalho, entre os participantes do mutirão. Para eles o material aparente dispensava o trabalho adicional de acabamento de paredes construídas o chapisco, emboço, reboco, massa corrida e pintura - proporcionando o aproveitamento máximo das vantagens deste tipo de material. Além disso, de acordo com Arantes (2010), o bloco aparente também deixa amostra, que aquela obra é fruto de um trabalho coletivo intenso dos próprios moradores.

Além disso, Arantes (2010) afirma que, O material aparente ${ }^{71}$ também deixa visível o aperfeiçoamento e os acertos de execução da laje a cada novo andar construído, dessa forma, no primeiro pavimento percebe-se as rebarbas e imperfeições resultantes de uma primeira concretagem, enquanto que nos pavimentos posteriores percebe-se uma progressão contínua no acabamento da laje, conforme figura 19.

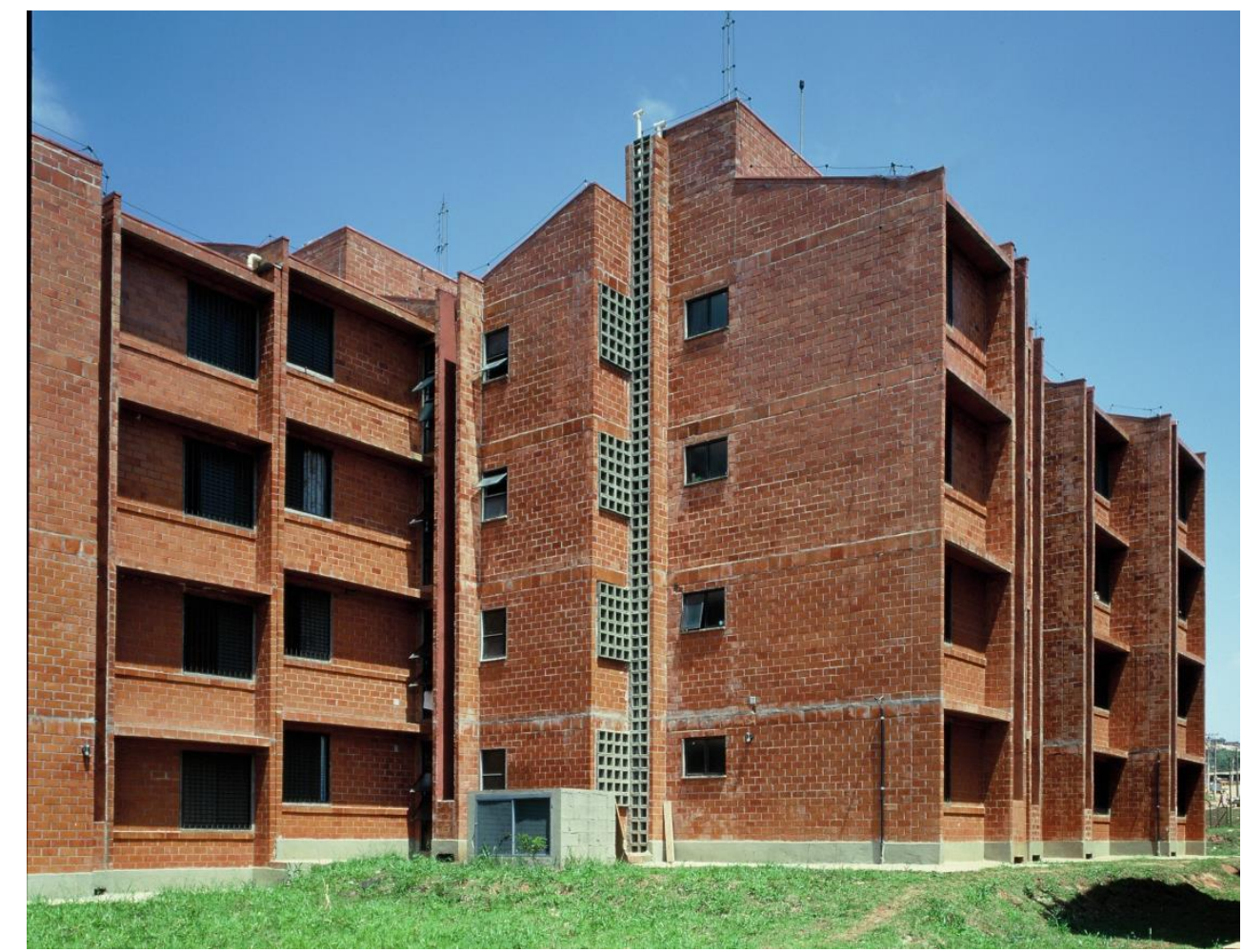

Figura 19| Vila União da Juta. Fonte| acervo USINA.

${ }^{71}$ Este aspecto do trabalho aparente remete a discussão do Sérgio Ferro e do grupo Arquitetura Nova. Para maiores informações sobre ver Arantes (2002). 


\subsubsection{Unidade habitacional}

Para o projeto das tipologias habitacionais considerou-se a importância de se ter uma diversidade tipológica que representasse a heterogeneidade dos agrupamentos familiares e os diferentes modos de uso, buscando compatibilizar as necessidades individuais com as coletivas.

Deste modo, a Vila União da Juta possui três diferentes tipologias habitacionais que foram definidas coletivamente com os moradores. Foi dada especial atenção para o dimensionamento das áreas das unidades habitacionais (aproximadamente $60 \mathrm{~m}^{2}$ ), considerando-se o número médio de componentes nas famílias a serem atendidas. Vale salientar que no caso da Juta existe uma variação tipológica pouco usual nos projetos de habitação social feitos pela CDHU, fato que garante maior grau de adaptação às diferentes necessidades habitacionais.
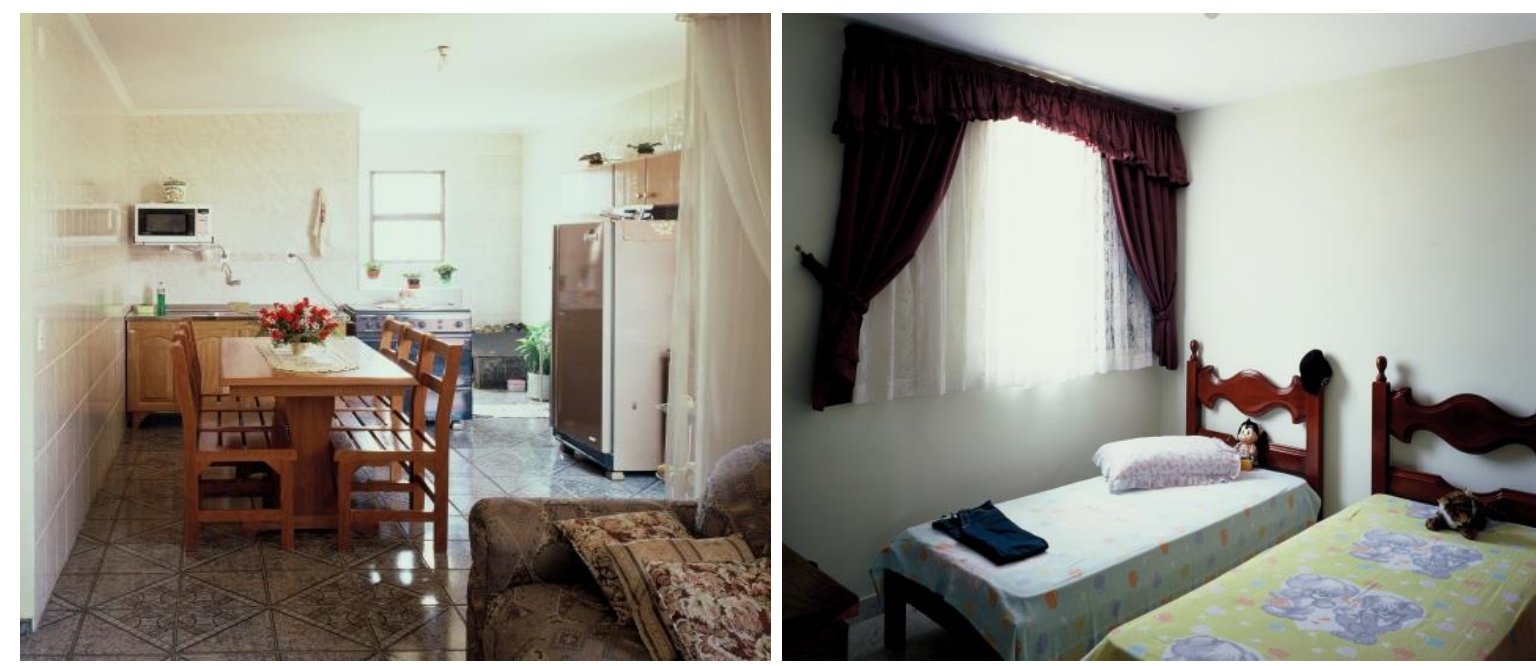

Foto 20 e 21 | Vila União da Juta, tipologias habitacionais. Fonte: acervo USINA.

No que se refere ao espaço e acabamento das unidades habitacionais da União da Juta (ver Figura 20 e 21), podemos perceber que optou-se por priorizar o atendimento ao espaço interno das habitações, pois entende-se que os acabamentos podem ser resolvidos após a construção. No entanto, por serem apartamentos dificilmente os 
espaços internos poderiam ser ampliados e ou reduzidos depois de construídos (ver Figura 22).

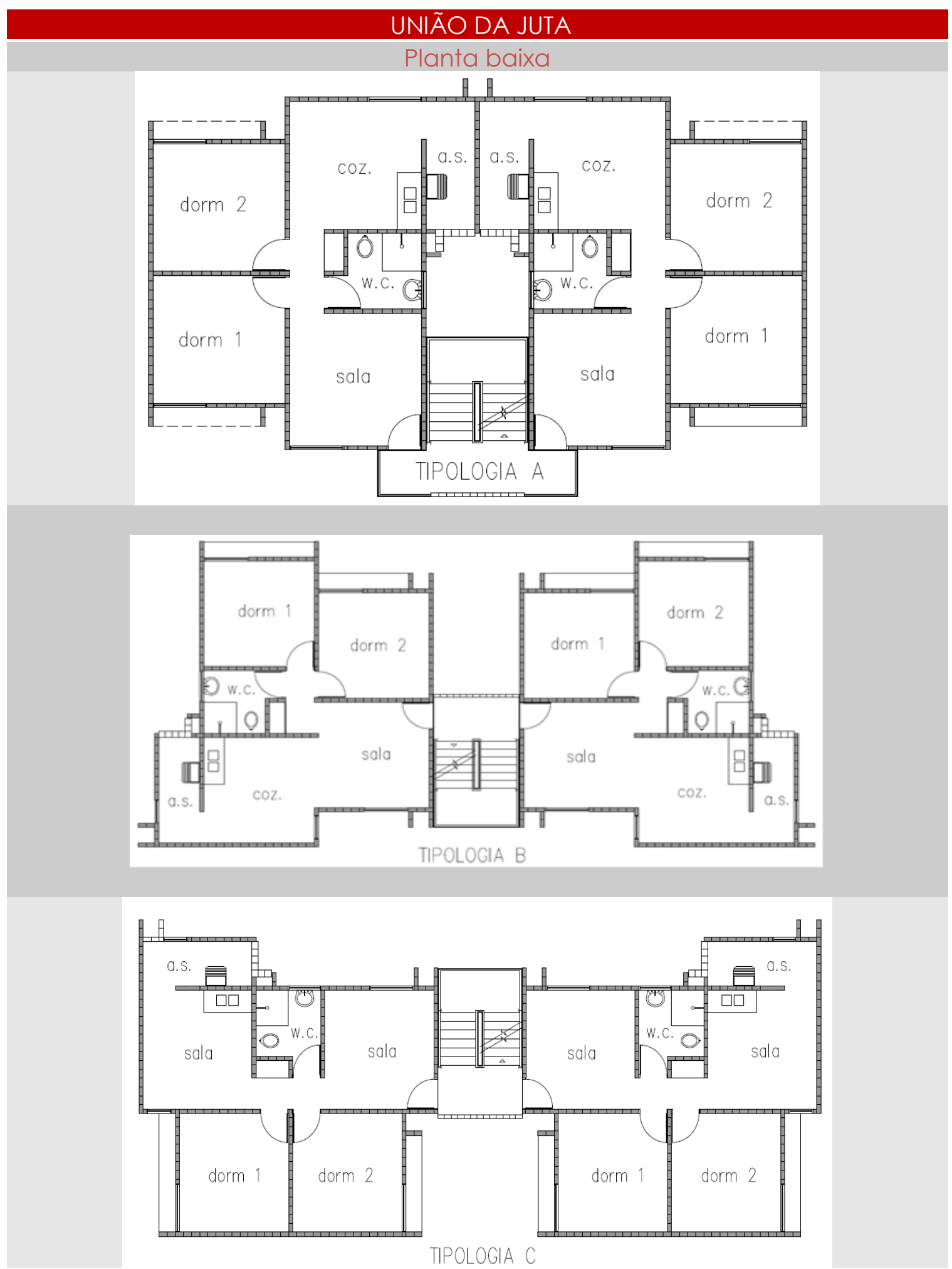

Figura 22| Planta baixa da Tipologias A, B e C respectivamente.

Fonte | acervo USINA 
A tipologia A $\left(63,45 \mathrm{~m}^{2}\right)$ é encontrada em dois prédios que perfazem um total de 16 apartamentos com área construída total de $1.126,80 \mathrm{~m}^{2}$. Na tipologia B $\left(67,98 \mathrm{~m}^{2}\right)$ temos seis prédios com um total de 48 apartamentos e área construída total de $3.533,71 \mathrm{~m}^{2}$. A tipologia $C\left(63,45 \mathrm{~m}^{2}\right)$ é composta por 12 prédios, com 96 apartamentos e um total de $6.632,54 \mathrm{~m}^{2}$ de área construída. Durante as entrevistas os moradores afirmaram que a tipologia $C$ foi a mais desejava, por manter a porta de entrada do apartamento não direcionada para a porta do vizinho.

Cada tipologia habitacional é composta por um agrupamento de quatro módulos básicos de: Módulo 1: 5,75m×3,50m - sala, circulação e banheiro; Módulo 2: 5,00m×3,50m - cozinha e lavanderia: Módulo 3 e 4: 3,375m×3,50m - dois dormitórios (ver Figura 23).

\begin{tabular}{|c|c|c|c|c|}
\hline & & $\begin{array}{l}\text { TIPOLOGIA A } \\
\text { Área útil }\left(\mathrm{m}^{2}\right)\end{array}$ & $\begin{array}{l}\text { TIPOLOGIA B } \\
\text { Área útil }\left(\mathrm{m}^{2}\right)\end{array}$ & $\begin{array}{l}\text { TIPOLOGIA C } \\
\text { Área útil }\left(\mathrm{m}^{2}\right)\end{array}$ \\
\hline Sala & \multirow{3}{*}{ Módulo 1} & 11,39 & 11,46 & 11,39 \\
\hline $\begin{array}{c}\text { Hall de } \\
\text { circulação }\end{array}$ & & 1,75 & 1,75 & 1,75 \\
\hline Banheiro & & 4,33 & 4,33 & 4,33 \\
\hline Cozinha & \multirow{2}{*}{ Módulo 2} & 11,39 & 11,46 & 11,39 \\
\hline Área de Serviço & & 4,21 & 4,21 & 4,21 \\
\hline Quarto 1 & \multirow{2}{*}{ Módulo 3 e 4} & 11,39 & 11,39 & 11,39 \\
\hline Quarto 2 & & 11,39 & 11,39 & 11,39 \\
\hline Área útil total & ------ & 55,85 & 55,99 & 55,85 \\
\hline $\begin{array}{c}\text { Área Construída } \\
\text { total }\end{array}$ & -..... & 63,45 & 67,98 & 63,45 \\
\hline
\end{tabular}

Figura 23 | Modulação a área útil para cada tipologia do MUJ. Fonte | USINA

O agrupamento destes módulos formam módulos maiores que podem ser agrupados de formas distintas compondo assim e tipologias diferentes, garantindo maior diversidade. Tal modulação possibilitou a concentração e a redução da área de circulação interna e o aproveitamento quase total dos espaços através de área util.

Até o momento pudemos perceber que o projeto de arquitetura e urbanismo da Vila União da Juta atende de forma muito inteligente aos requisitos mínimos que se espera de um projeto habitacional - disposição 
dos prédios, das quadras e das unidades habitacionais - apresentando soluções que são ao mesmo tempo econômicas e inovadoras, fato incomum na produção para este segmento populacional.

Além desses requisitos mínimos, pudemos perceber também um atendimento a requisitos complementares que representam um salto significativo na qualidade da moradia. Do ponto de vista programático, a associação do espaço doméstico à geração de renda, foi possível na União da Juta, com a instalação de serviços comunitários que fossem comandados pelos próprios moradores.

Desta forma, o projeto ofereceu às famílias a possibilidade de montar uma padaria comunitária, que além de ser gerida pela própria associação de moradores garantindo-lhes uma renda adicional para a manutenção do conjunto habitacional, também ofereceriam cursos de capacitação profissional para jovens e adultos nas áreas de panificação, salgados e doces, atendente de lanchonete, padeiro, confeiteiro, etc.

O MUJ pode ser considerado um caso particularmente expressivo no rol de projetos de arquitetura habitacional de interesse social e, sobretudo, de programas de promoção pública de construção por mutirão autogerido. Isto porque entre as distintas experiências, de âmbito estadual, este mutirão teve caráter precursor na forma de organização e participação dos futuros moradores, no tipo de enfretamento com o poder público e na qualidade do projeto arquitetônico.

A seguir, podemos verificar no depoimento de um morador o reconhecimento de que o Mutirão da Juta foi um processo diferenciado, principalmente por que lutaram para conseguir algo além do objeto habitação: 
tá tudo ok. Não vê que falta escola, falta um núcleo de saúde, falta...Falta tudo. Só a casa, a casa é bom, é bom você ter sua casa, mas só a casa não é tudo. Quer dizer depois da casa você precisa de saúde, precisa de educação, precisa de outros, de transporte, precisa do básico pra você poder viver bem. E tem gente que não vai atrás de nada. Só quer comer e dormir, comer e dormir. (Entrevistado B, MUJ, entrevista à autora, ago. 2010).

A implantação da autogestão em mutirões habitacionais é um processo longo e complexo, que envolve inúmeras contradições, podendo resultar em formas de assistencialismo barato e um "participacionismo"72 irreal.

Lopes (2010) aponta para a necessidade de "des-positivar" o pressuposto da participação, pois a partir do momento em que tal prática institucionaliza-se, ela perde força e captura outras práticas como a autogestão e a autonomia. Ainda neste sentido, acrescentamos que o participacionismo pode resultar em diferentes formas de interação, conforme o autor:

As estratégias participativas em políticas públicas podem proporcionar uma gama variada de interações políticas que vão desde formas arcaicas (clientelismo, populismo) até a negociação democrática na presença de movimentos sociais organizados. Esta nos parece a principal característica das estratégias participativas em políticas públicas. (Silveira, 1987, p.3)

Em meio a inúmeras contradições, emerge uma questão importante: Para que servem as práticas autogestionárias se numericamente elas são limitadas e estão longe de minimizar as necessidades habitacionais? Podemos afirmar, que o êxito do mutirão não está no número de unidades habitacionais produzidas, mas naqueles que participam do processo:

\footnotetext{
72 Lopes (2010, p. 16) "a participação proposta pelos arquitetos, ainda que numa escala menor e subordinada aos planos urbanísticos (...) pretende de alguma forma que os diretamente interessados participem da produção de seus espaços". Entretanto, "tal forma de participação também não é emancipatório, pois como mostra Garry Stevens, os arquitetos (e seus clientes) estão submetidos a relações de poder sem que estejam totalmente conscientes disso".
} 
"[...] se não é possível disseminar a prática porque inexiste uma rede organizativa de base que dê conta dessa disseminação, $O$ êxito restringe-se aos que participam, relegando àqueles que não conseguem se inserir nos processos de mutirão - e são muitos - os velhos mecanismos de provisão habitacional: filas, produtos de péssima qualidade, inacessibilidade em virtude dos altos custos acessórios, etc.; se o padrão de verificação é o custo, aqui também a ideia de êxito tem que ser ponderada: quem incorpora as economias realizadas com a aplicação de mão-de-obra do futuro morador? Essa mão-de-obra não é gratuita - nunca foi e é, no mínimo, equivocado afirmar o contrário - e certamente seu valor é agregado ao produto. Mas qual o retorno efetivo com o investimento realizado? E quem se apropria desse retorno? Grande parte das vezes é o próprio Estado, como no caso de Fortaleza, por exemplo, que capitaliza esse retorno na forma de dividendos políticos: resta ao usuário uma pequena unidade habitacional em torno de $30 \mathrm{~m}^{2}$, situada a quilômetros do centro da cidade e precariamente atendida pelos serviços urbanos. Nos casos de São Paulo e Belo Horizonte, já é patente a verificação de como processos de urbanização populares - entre eles, os mutirões - realizam, ao longo do tempo, a reconquista e liberação de imensas áreas urbanas, antes descartadas, para o mercado imobiliário. Tais ponderações levaram-nos a abordar as já referidas "inovações" de forma bastante cuidadosa, procurando escapar de uma avaliação valorativa dos processos envolvidos e conduzindo nossas análises de forma a compreender como se superpunham, em cada um dos estudos, os diversos aspectos que, se numa primeira abordagem apareciam de forma positiva uma best practice - ou negativa - sobretrabalho -, acabavam instruindo valores contraditórios se iluminados com maior cuidado. Dessa forma, não há que se esperar desta pesquisa um compêndio em forma de receituário ou de recomendações pragmáticas, mas um extenso apanhado crítico que auxiliará, sim, em repensar a própria prática e inovar as "inovações". (LOPES; RIZEK, 2006, p.67-68).

Podemos afirmar que, experiências como o MUJ contribuem para nos mostrar que apesar da sua escala reduzida, representam uma ruptura com a forma de produção habitacional instituída naquela conjuntura.

Para o arquitetos representam uma inversão do paradigma clássico do profissional que trabalha a serviço do poder público. Também marca o fracasso do "projeto moderno" como forma de desenvolvimento socioeconômico.

Logo, para os movimentos sociais representa uma importante forma de luta política e de busca por autonomia. Ainda neste sentido, o MUJ demonstra a existência de soluções inovadoras na produção da moradia 
popular marcada pela autogestão da obra. Além disso, em termos arquitetônicos representa um salto qualitativo pouco existente nas soluções para moradia popular.

\section{CAPÍTULO 4 | CONSIDERAÇÕES FINAIS}

A análise da política de habitação popular desenvolvida no Brasil, durante os anos de 1964 e 1986, pelo Sistema Financeiro de Habitação (SFH) e pelo Banco Nacional de Habitação (BNH), mostrou a existência de um conjunto de heranças deixadas por este modelo que influenciou as políticas habitacionais desenvolvidas pelos estados e, também, na evolução institucional da CDHU.

Desta maneira, a própria companhia responsável pela execução das políticas de habitação - a CDHU, acabou reproduzindo as mesmas contradições do modelo BNH, ou seja, optou pelo desenvolvimento de uma política habitacional mantendo a lógica de produção de segregação socioespacial. Privilegiou-se atingir resultados quantitativos de redução dos déficits habitacionais em detrimento de projetos que visavam a qualidade dos espaços construídos e que enfrentavam a lógica de produção especulativa e produtiva.

À medida que os diferentes atores - Estado, órgãos públicos, movimentos sociais e arquitetos - se cruzaram engendraram um cenário ímpar na história do país e estabeleceram novas relações de poder, que constituíram-se em importantes horizontes para a formação de programas de habitação popular "alternativos".

Desta forma, cabem as seguintes questões: Qual a importância de experiências como o Mutirão União da Juta? Quais foram às limitações e as possibilidades? E para além desta dissertação: Como construir políticas públicas de produção de moradia popular que representem possibilidades efetivas de desenvolvimento e transformação? 
Diante desses questionamentos, não pretendemos trazer respostas únicas nem tampouco conclusões fechadas sobre a temática. Para além de uma avaliação reducionista sobre o mutirão União da Juta, como "boa arquitetura", rearticulamos os fios que compõem os retalhos da história desta experiência - processo, projeto, gestão e participação - que a tornam única e que, por isso, podem contribuir para o debate sobre o processo de produção da moradia popular.

O mutirão autogestionário União da Juta aparece como uma (re)invenção da prática de produção habitacional e como uma experiência que insinua uma subversão do padrão de construção de habitação popular da CDHU ou outras políticas públicas tal como o atual Programa Minha Casa Minha Vida (PMCMV).

Segundo dados da Caixa Econômica Federal, o PMCMV, possui a perspectiva de construção de 2 milhões de unidades habitacionais, sendo que $60 \%$ para famílias com renda de até três salários mínimos vigentes em 2010. No entanto, de todo subsídio público disponibilizado pelo programa habitacional, apenas $3 \%$ será destinado a entidades sem fins lucrativos, cooperativas e movimentos sociais, ou seja, $97 \%$ dos recursos são destinados à oferta e produção direta por construtoras privadas. Desta forma, podemos observar que o programa propõe diálogo direto com representantes dos setores imobiliários e da construção civil e praticamente desconsidera outros setores da sociedade civil que historicamente vinham produzindo formas alternativas de moradia popular.

O PMCMV é anunciado como uma política anti-cíclica com objetivos sociais, entretanto, "não será uma política anticíclica social, mas uma política imobiliária que terá efeitos de médio prazo sobre o mercado de trabalho"73. Neste sentido, o PMCMV, corrobora a necessidade e o

\footnotetext{
${ }^{73}$ ARANTES, P. F.; FIX, M. (2009).
} 
esforço no sentido de conhecer, recuperar e reavivar experiências de (re)invenção como o Mutirão União da Juta.

Contudo, segundo Lopes e Rizek (2006), as suas "inovações" precisam ser vistas com cuidado, pois, se por um lado pode ser considerada como uma boa prática, por outro lado, também possui o desafio de enfrentar a questão da utilização da mão-de-obra mutirantes como sobretrabalho. Para isso, é necessário o aperfeiçoamento da gestão coletiva de todo o processo de produção da moradia.

É importante fazer uma ressalva a cerca da atual inserção de escritórios de arquitetura conceituados que realizam projetos de habitação de interesse social na periferia. Esses escritórios estão realizando alguns projetos de interesse social aclamados como paradigmáticos, por apresentarem estética mais interessantes que o modelo de conjunto habitacional produzidos pelo SFH/BNH.

No entanto, acreditamos que é preciso avaliar em que medida as análises de tais projetos levam em consideração algum lastro de transformação, já que tratam-se de projeto de interesse social. Também precisam ser analisados até que ponto esse projetos tem gerado um contraponto real aos modelos paradigmáticos do BNH. Assim, são no máximo a inserção de nova estética arquitetônica na periferia.

Acreditamos que não se promove uma transformação social, sem modificar-se o Estado e os agentes sociais atuantes em atores de transformação. Dessa forma, até mesmo os projetos de arquitetura de interesse social também deveriam incorporar na vida dos moradores algum questionamento da própria realidade, visando contribuir para a sua transformação.

Ainda neste sentido, consideramos que um projeto de arquitetura de interesse social pode levantar algum debate para além da estética, ou seja, a moradia popular apresenta-se como manifestação da vida interna 
das coisas e das relações de produção. No entanto, se avaliada por si só não irá demonstrar nenhuma transformação da realidade social, mas sim reforçará a percepção fragmentada sobre o processo, amplo e complexo, que envolve a produção habitacional de interesse social.

Desta forma, a visão por fragmentos faz com o que processo de trabalho no canteiro não represente nenhuma possibilidade de emancipação. Também não desenvolve uma percepção crítica sobre a realidade para que partir daí, possamos, enquanto profissionais comprometidos com as questões sociais, utilizar as ferramentas que a arquitetura nos fornece para interferir de forma politizada na produção de moradia popular.

Consideramos que é preciso experimentar diversas formas de questionamento das estruturas tradicionais e que neste sentido, o Mutirão União da Juta se realiza enquanto tal.

A solução para a questão da moradia perpassa por diferentes formas de produção e o mutirão com autogestão representa uma das possibilidades de enfrentamento da lógica do empresariamento urbano e habitacional. A prevalência de apenas um modelo de produção habitacional baseado na transformação da habitação em mercadoria mostra-se incapaz de resolver as necessidades habitacionais da população empobrecida, e ainda menos de melhorar as condições de moradia dos pobres em nossas cidades.

A cada novo acúmulo de experiências como o Mutirão União da Juta, teremos novas possibilidades de construção de uma agenda para a autogestão. Os movimentos de luta por moradia e as assessorias técnicas que atualmente se organizam tem procurado resistir e construir uma outra agenda para a política habitacional, retomando certos aspectos da agenda da autogestão, atualizando-os aos novos conflitos políticos, repensando a própria prática e criando inovações. 


\section{REFERÊNCIAS BIBLIOGRÁFICAS}

20 anos do Fundo Nacional de Moradia Popular, União Nacional. Disponível em: $<w w w . u n m p . o r g . b r / i n d e x . p h p ? o p t i o n=c o m \_d o c m a n \& t a s k . p d f>$. Acesso, mar. 2013.

AGENDA DA PREFEITA. 09 de Abril de 1989. A casa, enfim, em ordem, e os serviços públicos funcionando. Disponível em: tp://agendadaprefeita.wordpress.com/201 1/04/1 1/09-de-abril-de-1989/. Acesso em abril de 2011.

ARAGÃO, José Maria. Sistema Financeiro da Habitação: Uma Análise sociojurídica da gênese, desenvolvimento e crise do Sistema. Curitiba: Juruá, 1999.

ARANTES, P. F.; FIX, M. Como o governo Lula pretende resolver o problema da habitação. In: Caros Amigos, 2009. Disponível em: http://carosamigos.terra.com.br. Acesso em Nov. 2010.

ARANTES, Pedro Fiori. Arquitetura Nova: Sérgio Ferro, Flávio Império e Rodrigo Lefèvre - de Artigas aos mutirões. Posfácio de Roberto Schwarz. São Paulo: Ed. 34, 2002.

ARANTES, Otília; VAINER, Carlos; MARICATO, Ermínia. A cidade do pensamento único: desmanchando consensos. Petrópolis: Vozes, 2000. 192 p.

ARRETCHE, Marta Teresa da Silva. Estado e Mercado na Provisão Habitacional: três modelos de política. Dissertação de mestrado. Campinas/SP: IFCH/UNICAMP, 1990.

Política Habitacional entre 1986 e 1994. In ARRETCHE, Marta e RODRIGUEZ, Vicente (Orgs.) Descentralização das Políticas Sociais no Estado de São Paulo. São Paulo: FUNDAP: FAPESP; Brasília: IPEA, 1998.

AZEVEDO, Sérgio; ANDRADE, Luís Aureliano, Gama de. Habitação e Poder, da Fundação da Casa Popular ao BNH. Rio de Janeiro: Zahar, 1982.

BARAVELLI, José Eduardo. O cooperativismo uruguaio na habitação social de São Paulo: das cooperativas FUCVAM à Associação de Moradia Unidos de Vila Nova Cachoeirinha. Dissertação de Mestrado. FAU-USP, 2006. 
BLAY, Eva A. Eu não tenho onde morar: vilas operárias na cidade de São Paulo. São Paulo: Nobel, 1985.

BOLAFFI, Gabriel. Habitação e Urbanismo: O problema e o falso problema. p. 43 e 44 in A produção Capitalista da casa e da cidade. São Paulo: Editora Alfa-Omega, 1979.

. Os mitos sobre o problema da habitação. Espaço e Debates, (16) 24-31, 1986.

. Para uma nova política habitacional e urbana: possibilidades econômicas, alternativas operacionais e limites políticos. Habitação em Questão. In: VALLADARES, L. do P. (org.). Repensando a habitação no Brasil. Rio de Janeiro: IUPERJ/Zahar, 1982.

BONDUKI, Nabil. Origens da habitação social no Brasil: arquitetura moderna, lei do inquilinato e difusão da casa própria. São Paulo: Estação Liberdade, 2004.

Nabil. Habitação e Autogestão. Construindo Territórios de Utopia. Rio de Janeiro: FASE, 1992. 181 p.

BOURDIEU, Pierre. Efeitos do lugar, In: BOURDIEU, P. (coord.), A. Accardo et. al. A Miséria do Mundo, Petrópolis, RJ: Vozes, 1997.

CINTRA, Antônio Octávio. Prefácio In: Habitação e Poder, da Fundação da Casa Popular ao BNH. Rio de Janeiro: Zahar, 1982;

COELHO, Will Robson. O déficit das moradias: instrumento para avaliação e aplicação de programas habitacionais. Dissertação (Mestrado em Arquitetura e Urbanismo) - Escola de Engenharia de São Carlos, Universidade de São Paulo, São Carlos, 2002. Disponível em: <http://www.teses.usp.br/teses/disponiveis/18/18131/tde-19032003155800/>. Acesso em: 2011-11-25.

Conjunto habitacional CECAP-Cumbica. Revista Desenho n. 5, 1973.

Disponível em: http://www.arquiteturabrutalista.com.br/fichastecnicas/DW\%201967-96/1967-96-fichatecnica.htm. Acesso em: mar. 2012.

Conjunto Águia de Haia," Casinhas do Quércia ". Cidade A. E. Carvalho. SãoPaulo. Disponível em: http://conjuntoaguiadehaia.webnode.com.br/ Acesso em: mar. 2012. 
DAGNINO, Evelina. Sociedade civil, espaços públicos e a construção democrática no Brasil: limites e possibilidades. In: DAGNINO, E. (orgs.). Sociedade civil e espaços públicos no Brasil. São Paulo: Paz e Terra, 2002.

DAGNINO, Evelina (Org.). Confluência perversa, deslocamentos de sentido, crise discursiva. In: DAGNINO, E. (Org.); Alberto J. Olvera (Org.); Aldo Panfichi (Org.). La Disputa por la Construcción Democrática en América Latina. 1a. Ed. Cidade do México: Fondo de Cultura Económica, 2006.

ENGELS, Friedrich. A questão da habitação: reeducação de hábitos e programação de metas. São Paulo: Insular, 1988.

FELTRAN, Gabriel de Santis. Desvendar a política na periferia: histórias de movimentos sociais em São Paulo. Associação Editorial Humanitas (FFLCH/USP): FAPESP, 2005.

FERREIRA, J. S. W. Produzir casas ou construir cidades? Desafios para um novo Brasil urbano. Parâmetros de qualidade para a implementação de projetos habitacionais e urbanos. São Paulo: LABHAB: FUPAM, 2012

FERRO, Sérgio. Nota sobre "O vício da Virtude". in Novos Estudos - CEBRAP, 2006, n. 76, pp. 229-234.

. O Canteiro e o Desenho. São Paulo, Projeto, 1987

Nota sobre a Usina, 2004. Disponível em:

FREITAS, Eleusina Lavôr Holanda de. Como qualificar conjuntos habitacionais populares. Brasília: Caixa Econômica Federal, 2004.

FUNDAÇÃO SEADE. Atlas Seade da economia paulista. São Paulo, 2006. Disponível em:<http://www.seade.gov.br/produtos/atlasecon>. Acesso em: 25 de agosto de 2011.

GOHN, Maria da Glória. Novas teorias dos movimentos sociais. 2. ed. São Paulo: Loyola, 2009c.

HADDAD e Alckmin debatem parceria inédita para construção de casas. Prefeitura de São Paulo. Secretaria Executiva de Comunicação. 5 de abril 2013. Disponível em:

<http://www.prefeitura.sp.gov.br/cidade/secretarias/comunicacao/notici as/? $p=145532>$. Acesso em: 6 de abril de 2013. 
HARVEY, David. Do gerenciamento ao empresariamento: a transformação da administração urbana no capitalismo tardio. Revista Espaço e Debates. São Paulo: Cortez, n. 39, p. 48 - 64, 1996.

IKUTA, Fernanda Keiko; JUNIOR, Antônio Thomás. A questão da moradia para além da re-produção social. Scripta Nova. Revista eletrônica de geografia y ciências sociales. Barcelona: Universidad de Barcelona, 1 de agosto de 2005, vol IX, num. 1999. <http: // WWW. ub.es/geocrit/sn/sn*19499.htm> [ISSN: 1138-9788].

LEFEBVRE, Henri. O direito à cidade. São Paulo: Documentos, 1991.

LIMA, Fernando Carlos G. C.; FIORI, Jorge; MAGALHÃES, Paulo; TINOCO, Galeno; ZONINSEIN, Jonas; SILVEIRA, Caio Marcio L. P. da; GOMES, Maria Celia e BASTOS, Carlos M. Sistema financeiro de habitação e programas habitacionais alternativos: diagnóstico e perspectivas. Instituto de Economia industrial/Universidade Federal do Rio de Janeiro (IEI/UFRJ), 1989. (Discussão n 193)

LOPES, João Marcos de Almeida. O anão caolho. Novos estudos - CEBRAP [online]. 2006, n.76, pp. 219-227. ISSN 0101-3300.

Sobre arquitetos e sem-tetos. Técnica e arquitetura como prática política. São Carlos, 2011. Livre Docência Escola de Engenharia de São Carlos. Instituto de Arquitetura e Urbanismo de São Carlos, Universidade de São Paulo.

; RIZEK, Cibele Saliba. O mutirão autogerido como procedimento inovador na produção da moradia para os pobres: uma abordagem crítica. In: Adauto Lucio Cardoso; Alex Kenia Abiko. (Org.). Procedimentos de gestão habitacional para população de baixa renda (Coletânea Habitare; v.5). 1 ed. Porto Alegre: ANTAC, 2006, v. 1, p. 52-83.

MAGALHÃES, Paulo; SILVEIRA, Caio Marcio L. P. da; MAGALHÃES, Maria Alice. Programas governamentais de autoconstrução no Brasil: um estudo comparativo. Rio de Janeiro: Universidade Federal do Rio de Janeiro, Instituto de Economia Industrial, 1989.

MARICATO, Ermínia (org.). Autoconstrução, a arquitetura possível. In: MARICATO, Ermínia. A produção capitalista da casa (e da cidade) no Brasil Industrial. São Paulo: Ed. Alfa-Ômega, 1979.

. Ermínia. Política Habitacional no Regime Militar. Do milagre brasileiro à crise econômica. Rio de Janeiro. Ed. Vozes, 1987. 
Movimento dos Trabalhadores sem Terra Leste I - UMM; CMP. Regulamento Interno, São Paulo, 2010

MUTNER, Yvone. A periferia como fronteira de expansão do capital. São Paulo: Edusp, 1999.

Memorial descritivo do ante-projeto de urbanização da União da Juta ORNSTEIN, Sheila Walbe; ROMÉRIO, M. Avaliação Pós-Ocupação do Ambiente Construído. São Paulo, Studio Nobel/EDUSP, 1992.

OLIVEIRA, Francisco de. O Vício da Virtude - Autoconstrução e acumulação capitalista no Brasil. In: Novos Estudos-CEBRAP, 2006, n. 74, pp. 67-85.

PULHEZ, Magaly Marques. Espaços de favela, fronteiras do ofício: história e experiências contemporâneas de arquitetos em assessorias de urbanização. São Carlos: EESC - USP, Dissertação de mestrado, 2007.

Conforme as instruções: a tipificação do habitat popular na produção de habitação social no Brasil. In: XIV ENCONTRO NACIONAL DA ANPUR, ANAIS. Rio de Janeiro, 2011.

Relatório de Solicitação de Recursos Extraordinários, Associação de Moradores do Mutirão União da Juta e Assessoria Técnica, USINA, São Paulo, 1992.

Regulamento Interno do Movimento dos Trabalhadores Sem-Terra Leste 1 União dos Movimentos de Moradia (UMM) e Central do Movimentos Populares, 2010.

RIBEIRO, Luiz. C. Q.; AZEVEDO, Sérgio. A Crise da Moradia nas grandes cidades: da questão da habitação à reforma urbana. Rio de Janeiro: UFRJ, 1997.

RIZEK, Cibele Saliba; BARROS, Joana da Silva; BERGAMIN, Marta de Aguiar. A política de produção habitacional por mutirões auto gestionários: construindo algumas questões. Revista Brasileira de Estudos Urbanos e Regionais (ANPUR), v. 5, n. 1, p. 185-187, 2003.

RODRIGUES, Evaniza e PESSINA, Leonardo. Programa Paulista de Mutirão e Autogestão do Governo do Estado de São Paulo (1995 - 1997). Trabalho da disciplina Desenho e Gestão do Território Municipal, PUC-CAMP, Campinas, 1997. 
ROYER, Luciana de O. Financeirização da política habitacional: limites e perspectivas. São Paulo: USP / Faculdade de Arquitetura e Urbanismo, 2009.

SACHS, 1999. Políticas Públicas e habitação Popular. São Paulo: Editora da Universidade de São Paulo, 1999.

SADER, Eder. Quando novos personagens entraram em cena: experiências, falas e lutas dos trabalhadores da grande São Paulo, 1970 80. Rio de Janeiro: Paz e Terra, 1988.

SANTOS, Milton. A Urbanização brasileira. São Paulo: Editora Universidade de São Paulo, 2008.

SÃO PAULO (Estado). Companhia de Desenvolvimento Habitacional. Sugestões para a alteração das condições de financiamento habitacional para a população de baixa renda. São Paulo: CDH, 1987.

SÃO PAULO (Estado). Secretaria Estadual da habitação. Companhia de Desenvolvimento Habitacional e Urbano. Manual: Programa Paulista de Mutirão. São Paulo: CDHU, 1993.

SÃO PAULO (Estado). Secretaria Estadual da habitação. Companhia de Desenvolvimento Habitacional e Urbano. Programa de Construção em Mutirão com Associações Comunitárias. Manual de Operacionalização. São Paulo: CDHU, 1993(a).

SÃO PAULO (Estado). Companhia de Desenvolvimento Habitacional e Urbano. Regulamento do Convênio UMM - Mutirão. São Paulo: CDHU, 1992.

SÃO PAULO (Estado). Companhia de Desenvolvimento Habitacional e Urbano. Regulamento Programa Paulista de Mutirão. São Paulo: CDHU, 1995.

SÃO PAULO (Estado) Companhia de Desenvolvimento Habitacional e Urbano. Custos de produção - empreendimentos habitacionais CDHU. São Paulo: CDHU, 1999.

SECRETARIA DE ESTADO DA HABITAÇÃO. COMPANHIA DE DESENVOLVIMENTO HABITACIONAL E URBANO. Demonstrações contábeis relativas ao exercício findo em 31 de dezembro de 2010: Relatório da Diretoria. São Paulo: CDHU, 2011.

SCHWARZ, Roberto. Prefácio com perguntas. In: Crítica à razão dualista/O Ornitorrinco. São Paulo: Boitempo Editorial, 2003. 
SIMMEL, George. A metrópole e a vida mental. In: VELHO, O. G. O fenômeno urbano. Rio de Janeiro, Zahar Editores, 1979.

SILVEIRA, Caio Marcio L. P. da et AL. A noção de participação em políticas públicas: programas habitacionais alternativos. Rio de Janeiro: UFRJ/IEl, 1987.39p.

SILVIO TORRES apresenta PPP do Centro em Workshop na Universidade Mackenzie. 6 maio 2013. Disponível em:

http://www.habitacao.sp.gov.br/noticias/viewer.aspx?26MHpElw5ok=>. Acesso em: 8 de maio de 2013.

Sobre os trabalhos da USINA, Revista Urbânia, n 3, pág. 49 a 59

VALLADARES, Lícia do Prado. Estudos recentes sobre a Habitação no Brasil: resenha da literatura. In: VALLADARES, L. do P. (coord.). Repensando a habitação no Brasil. Rio de Janeiro: IUPERJ/Zahar, 1983.

VITRUVIUS. Entrevista, Flávio Lefèvre. Disponível em:

http://www.vitruvius.com.br/revistas/read/entrevista/01.001/3352). Acesso em: abr. 2012.

TOURAINE. Um nouveau paradigme. Pour comprendre le monde d'ajourd'hui. Paris, Fayard, 2005. p.18-19 


\section{ANEXO 1 \\ Regulamento de Obras}

\section{BEGULAMENTO DE OBRA}

\section{Horários e Condições de Trabalho:}
*Trabalho: - será das 8:00 às 17:00hs, havendo tolerância de 20 minutos, após os quais será considerado falta.
- o mutirão funcionará principalmente nos sábados, domingos e feriados.
- haverá prorrogação da jornada de trabalho quando o prazo determinado estiver comprometido caso haja mateiral com risco de estragar. Fica à critério do coletivo juntamente com a Assessoria Técnica a prorrogação do horário de trabalho para a conclusão das tarefas bem como o trabalho nos feriados.
* Faltas: $\quad$ - as faltas deverão ser justificadas. As justificativas das faltas serão avaliadas em 1⿳亠口冋 instância pela coordenação e na $2^{\mathbf{a}}$ instância pela Assembléia Geral. Tais faltas terão que ser repostas em 30 dias.
- a eliminação do mutirante acontecerá quando da $3^{\circ}$ falta não justificada.
* Chuva: - no caso de chuva, o mutirante deverá comparecer na obra, cabendo a dispensa ou não.
*Almoço: - das 12:00 às 13:00hs. 0 mutirante terá o direito de 1 hora para almoço e descanso.

\section{Compromisso dos mutirantes:}

* Participações mensais: o titular deverá cumprir 06 participações mensais no trabalho do mutirão.

* Participações semanais: o mutirante cumprirá 18 horas semanais trabalhadas. As horas serão computadas apenas para um membro de cada família (titular ou substituto). Os voluntários trazidos pelos mutirantes terão suas horas computadas para 0 coletivo.

* Uso das ferramentas: o mutirante será responsável pela ferramenta durante a obra, no caso de extravio ou negligência deverá pagar o valor da ferramenta. $\mathrm{Na}$ devolução das ferramentas, elas deverão ser entregues no almoxarifado limpas. Não havendo tarefa a ser concluída, o mutirante poderá ter 15 minutos antes para limpar e guardar a ferramenta, ao término do expediente.

* Uso do crachá: será obrigatório o uso do crachá de identificação durante a obra para todos os mutirantes (inclusive substitutos e/ou voluntários).

*Participação no trabalho: o mutirante deverá seguir a orientação do encarregado pelo grupo de trabalho e da Assessoria Técnica, sendo que as discordâncias deverão ser discutidas pelo grupo, em reuniöes previstas para esta finalidade.

\section{Bebidas Alcoólicas}

Não será permitido o uso de bebidas alcoólicas, nem a permanência de pessoas em estado de embriaguez, durante a obra. 


\section{Segurança} obra.

Por motivo de segurança será obrigatório o uso de roupas adequadas e capacete na

\section{Punições}

O mutirante será advertido por até 3 vezes quando no não cumprimento das regras estabelecidas neste regulamento

As advertências serão feitas da seguinte forma:

a) verbal

b) por escrito

c) pela Assembléia Geral

A desconsideração das advertências por parte do mutirante acarretará na expulsão da família do mutirão.

\section{Recursos do Mutirante}

O mutirante poderá levar à Assembléia Geral quaisquer assuntos correspondentes ao mutirão (punição, mudança de normas etc.).

\section{Marreteiros}

Não será permitida a percorrência de marreteiros de nenhuma espécie na obra.

\section{Livro de Apontamento de Presença}

Todos os mutirantes deverão assinar o livro de ponto na entrada e na saída.

\section{Desistências}

Caso a família desista ou seja excluída durante o andamento da obra, sua vaga será transferida para outra família da lista de espera. As horas trabalhadas até então, não serão remuneradas e deverão ser consideradas para todo o grupo.

\section{Validade deste Regulamento}

Este regulamento tem validade desde a data de sua aprovação pela Assembléia Geral até o final da obra.

\section{Alterações neste Regulamento}

As modificações e acréscimos a este Regulamento poderão ser feitos após a discussão em Assembléia Geral e aprovação da maioria simples. 
ANEXO 2

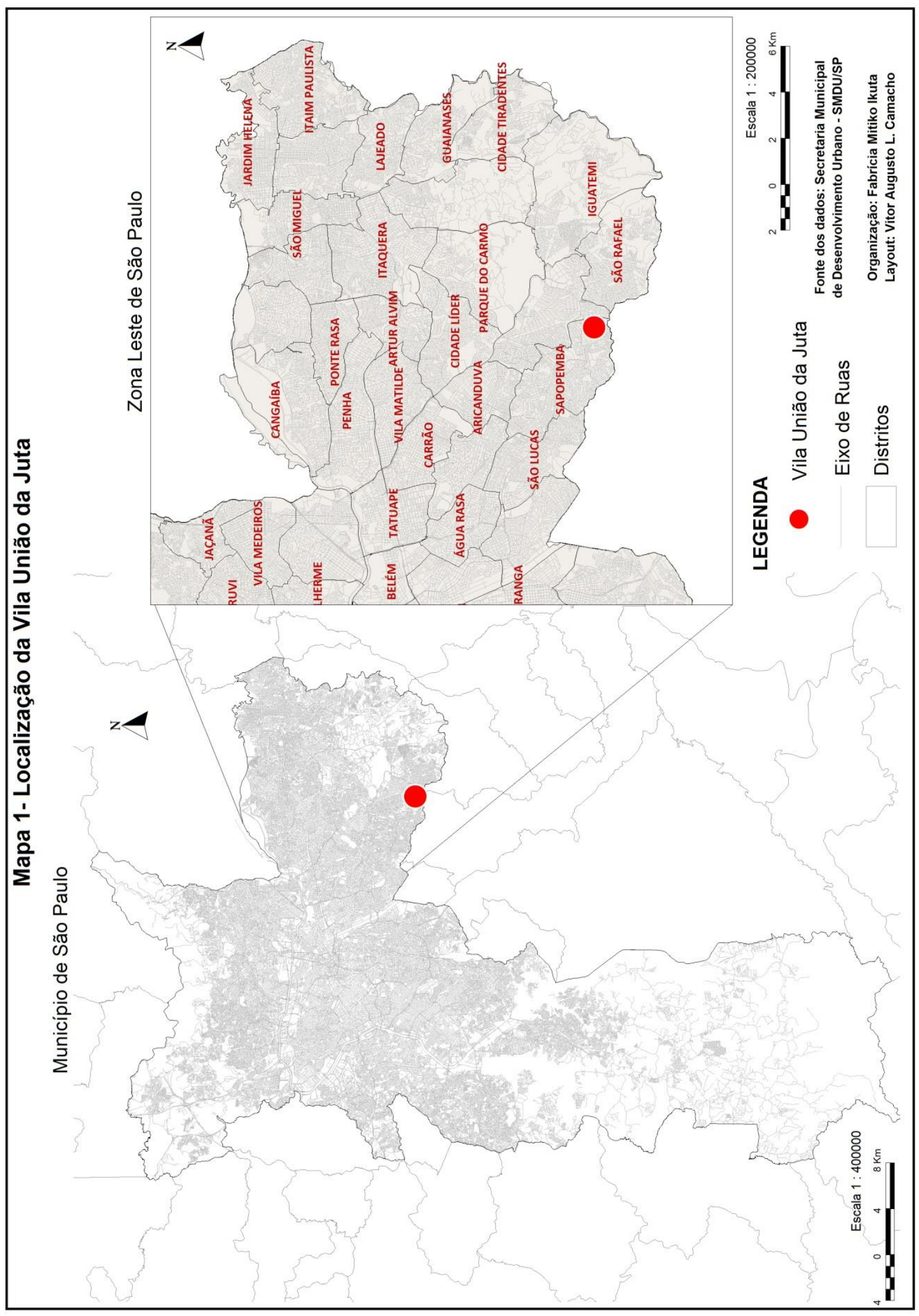




\section{ANEXO 3 \\ FICHA DE APOIO PARA CADASTRAMENTO}

Indicação dos principais grupos de tarefas da obra e de suas funções e Comissões da Associação União da Juta.

\section{GRUPOS DE TAREFA}

1. Movimentação de terra: escavações e aterros, construção de muros de arrimo e calçadas, manutenção de ruas e passagens;

2. Infraestrutura: Assentamento de canaletas de águas pluviais, execução das redes externas de energia, de água, de esgotos e águas pluviais;

3. Carpintaria: Fabricação de formas para pré-moldados, montagem dos escoramentos, dos andaimes e dos telhados, instalação das calhas e rufos.

4. Ferragem: corte, dobra e montagem das armaduras das paredes, das cintas e dos muros de arrimo.

5. Argamassa: processamento de concretos e de argamassas.

6. Alvenaria: levantamento das alvenarias, assentamento de elementos vazados, limpeza da alvenaria aparente, chapisco e emboço

7. Concretagem e Lajes: montagem das lajes e concretagem das lajes e canalestas.

8. Hidráulica: montagem dos kits de hidráulica e de esgoto, locação e instalação dos kits, instalação dos dutos de águas pluviais, instalação das bombas e das cisternas.

9. Elétrica: montagens dos kits de elétrica, instalação dos dutos, montagem da iluminação externa e interna, assentamento de caixas, enfiação, instalação de bombas, centros de medição e para-raios. 
10.Manutenção: recolhimento, seleção e destinação de materiais reutilizáveis (ferro, madeira, cerâmica, etc.), limpeza do canteiro, recolhimento de lixo.

11.Pré-fabricação: fabricação de degraus, contramarcos, canaletas de águas pluviais, elementos vazados etc.

\section{COMISSÕES DE TRABALHO}

1. Cozinha

2. Creche

3. Esporte

4. Cultura

5. Movimento de Moradia

6. Conselho Fiscal

7. Compras

8. Apontamento

9. Almoxarifado 